\title{
Torture and other Cruel, Inhuman or Degrading Treatment or Punishment
}

A Comparative Study between International law, Islamic Jurisprudence and the Iranian Legal System

By Ali Mokhtari

Student number: 0147946

Under supervision of Prof. Peter Leuprecht

A thesis submitted to McGill University in partial fulfillment of the requirements of the degree of LLM

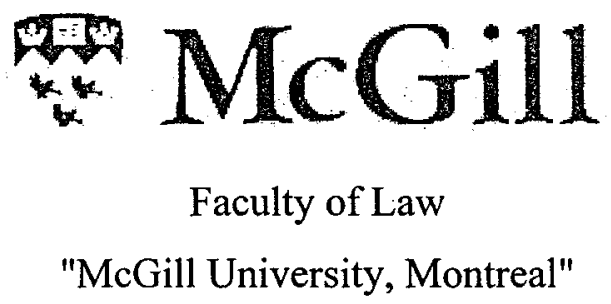

August 2004

(C) 2004 by Ali Mokhtari 


$\begin{array}{ll}\begin{array}{l}\text { Library and } \\ \text { Archives Canada }\end{array} & \begin{array}{l}\text { Bibliothèque et } \\ \text { Archives Canada }\end{array} \\ \begin{array}{l}\text { Published Heritage } \\ \text { Branch }\end{array} & \begin{array}{l}\text { Direction du } \\ \text { Patrimoine de l'édition }\end{array} \\ \begin{array}{l}\text { 395 Wellington Street } \\ \text { Ottawa ON K1A 0N4 }\end{array} & \begin{array}{l}\text { 395, rue Wellington } \\ \text { Ottawa ON K1A ON4 } \\ \text { Canada }\end{array} \\ \end{array}$

Your file Votre référence

ISBN: 0-494-12679-5

Ourfile Notre référence

ISBN: 0-494-12679-5

NOTICE:

The author has granted a nonexclusive license allowing Library and Archives Canada to reproduce, publish, archive, preserve, conserve, communicate to the public by telecommunication or on the Internet, loan, distribute and sell theses worldwide, for commercial or noncommercial purposes, in microform, paper, electronic and/or any other formats.

The author retains copyright ownership and moral rights in this thesis. Neither the thesis nor substantial extracts from it may be printed or otherwise reproduced without the author's permission.
AVIS:

L'auteur a accordé une licence non exclusive permettant à la Bibliothèque et Archives Canada de reproduire, publier, archiver, sauvegarder, conserver, transmettre au public par télécommunication ou par l'Internet, prêter, distribuer et vendre des thèses partout dans le monde, à des fins commerciales ou autres, sur support microforme, papier, électronique et/ou autres formats.

L'auteur conserve la propriété du droit d'auteur et des droits moraux qui protège cette thèse. $\mathrm{Ni}$ la thèse ni des extraits substantiels de celle-ci ne doivent être imprimés ou autrement reproduits sans son autorisation.
In compliance with the Canadian

Privacy Act some supporting forms may have been removed from this thesis.

While these forms may be included in the document page count, their removal does not represent any loss of content from the thesis.
Conformément à la loi canadienne sur la protection de la vie privée, quelques formulaires secondaires ont été enlevés de cette thèse.

Bien que ces formulaires aient inclus dans la pagination, il n'y aura aucun contenu manquant. 
To my wife, Bahar

for her support

and patience 


\section{Table of Contents}

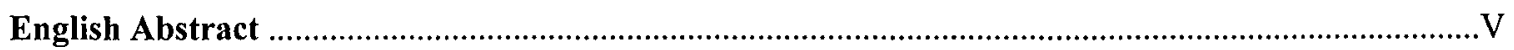

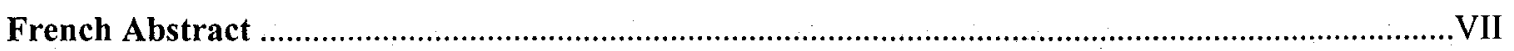

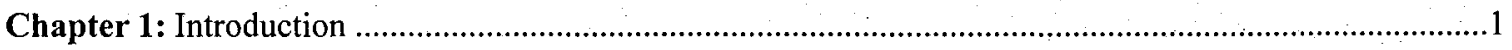

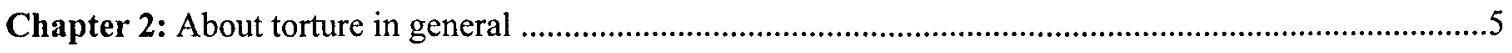

Section 2.1: A brief history of the use of torture, and of struggles against it ....................................

Section 2.2: Uses and purposes of torture ......................................................................................

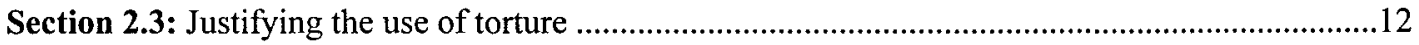

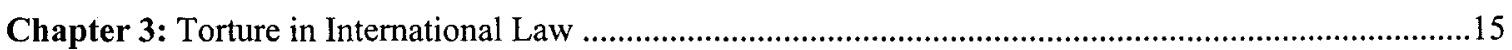

Section 3.1: The Hague Conventions …………………...........................................................

Section 3.2: Geneva Conventions ...........................................................................................

Section 3.3: UN efforts against torture ....................................................................................19

Sub-section 3.3.1: Universal Declaration of Human Rights (UNDHR).........................20

Sub-section 3.3.2: International Covenant on Civil and Political Rights (ICCPR).........21

Part 3.3.2.1: The UN Human Rights Committee .............................................23

Part 3.3.2.2: Special Rapporteur on Torture..................................................24

Sub-section 3.3.3: Standard Minimum Rules for the Treatment of Prisoners ................25

Sub-section 3.3.4: Declaration on the Protection of All Persons from Being ................28

Sub-section 3.3.5: Code of Conduct for Law Enforcement Officials ..............................30

Sub-section 3.3.6: Principles of medical ethics relevant to the role of medical personnel, particularly physicians, in the protection of prisoners and detainees against torture and other cruel, inhuman or degrading treatment.......31

Sub-section 3.3.7: Convention Against Torture and Other Cruel, Inhuman or ................31

Part 3.3.7.1: Committee Against Torture .............................................................38

Part 3.3.7.2: Optional Protocol to the Convention Against Torture and Other

Cruel, Inhuman or Degrading Treatment or Punishment............................................................40

Sub-section 3.3.8: Body of principles for the protection of all persons under any form of

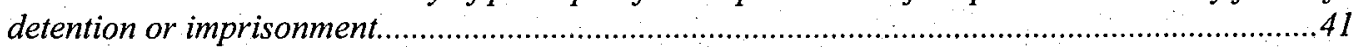

Sub-section 3.3.9: Convention on the Rights of the Child ..............................................43

Sub-section 3.3.10: Basic Principles for the Treatment of Prisoners, ............................44

Sub-section 3.3.11: Basic Principles on the Role of Lawyers .......................................44

Section 3.4: Regional efforts against torture ................................................................................45

Sub-section 3.4.1: European Convention on Human Rights .........................................45

Sub-section 3.4.2: European Convention for the prevention of torture and inhuman or degrading treatment or punishment ...............................................................................46

Sub-section 3.4.3: American Convention on Human Rights ...........................................47

Sub-section 3.4.4: African Charter on Human and Peoples' Rights .............................47 
Section 3.5: Other international efforts

Chapter 4: The Definition of Torture and other Cruel, Inhuman and Degrading Treatment or Punishment in International Law

Section 4.1: Torture: A Type of Cruel, Inhuman or Degrading Treatment or Punishment ..............55

Section 4.2: Lawful Sanctions and the question of corporal punishments ...................................58

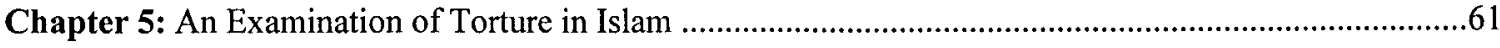

Section 5.1: Corporal Punishments are not Torture .......................................................61

Section 5.2: Modern reading of Islamic (Shia) jurisprudence to reconcile Islamic teachings with Human Rights Values

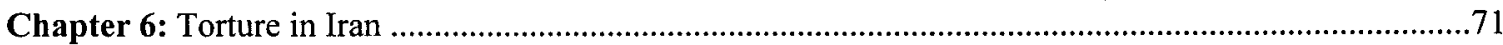

Section 6.1: Torture in Iran (Before 1907) …......................................................................71

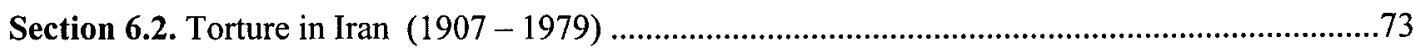

Sub-section 6.2.1: The first Iranian Constitution .................................................. 76

Sub-section 6.2.2: Parliamentary laws ............................................................ 77

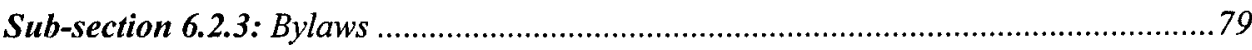

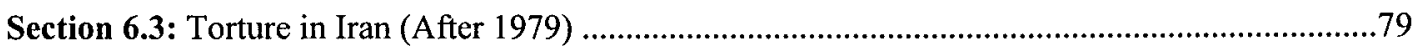

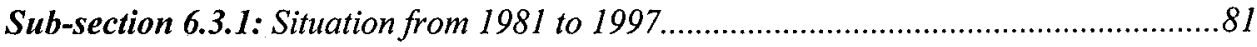

Sub-section 6.3.2: Situation from 1997 to 2004.........................................................87

Sub-section 6.3.3: Journalists, Political activists and Students in torture chambers .....92

Sub-section 6.3.4: Reviewing two famous cases ......................................................96

Part 6.3.4.1: Saeed Emami's wife case .....................................................96

Part 6.3.4.2: Zahra Kazemi case ............................................................ 97

Sub-section 6.3.5: Islamic Republic Constitution ......................................................100

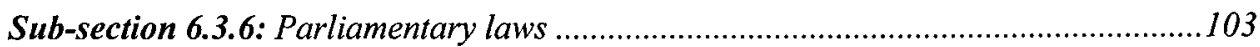

Sub-section 6.3.7: Bylaws .........................................................................110

Chapter 7: Examining the Iranian legal system with regard to the international standards on torture......112

Section 7.1: Definition of Torture in the Iranian Legal System ..................................................112

Section 7.2: Does Iranian Law maintain enough safeguards to prevent torture? ..........................113

Chapter 8: Recent efforts to eradicate torture in Iran .............................................................115

Section 8.1: Iranian legislative system in a glance ............................................................116

Section 8.2: Reformist MP's Efforts in the Sixth Parliament .................................................117

Sub-section 8.2.1: Bill of implementation of article 38 of the Constitution...................118

Sub-section 8.2.2: Bill to join the UN Convention Against Torture ...........................125

Sub-section 8.2.3: Bill to protect the rights of Accused or Convicted People................127

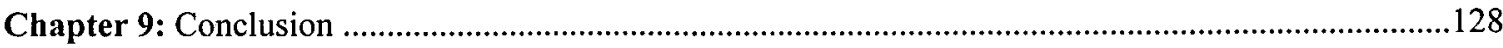

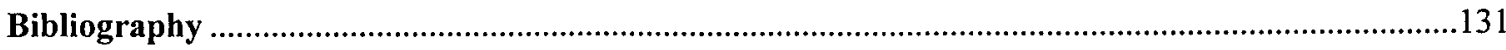




\section{English Abstract}

The elimination of torture and other cruel, inhuman or degrading treatment or punishment has been a dream for reformists and human rights activists for centuries. Yet, despite these efforts torture is still being practiced in many counties.

Global efforts have been made by individuals and national governments to proscribe the use of torture. Unfortunately, finding an internationally accepted definition of what types of activities constitute torture has been a major obstacle in the battle toward its abolition. Is it an activity qualified as torture only when it is carried out for certain purposes? At the heart of the debate lies the question of whether or not corporal punishment is a form of torture. While corporal punishment is contrary to international legislation, such as the UN Declaration on the Protection of All Persons from Being Subjected to Torture and Other Cruel, Inhuman or Degrading Treatment or Punishment, and the UN Convention Against Torture, aspects of corporal punishment remain acceptable according certain religious traditions. An example of this is found in traditional Islamic law, which has banned both torture and other cruel, inhuman and degrading treatment or punishment, when used for the express purpose of obtaining confessions or information. In other circumstances, however, severe corporal punishment is acceptable in Islamic law. As a result, some Islamic states whose domestic law is rooted in traditional Islamic law, justify their use of torture by invoking Islamic traditions: they claim that corporal punishment is derived from God's will. These states tend to consider its use as lawful sanctions, and it is made legal under their domestic law. In this paper, Iran is studied as one such state.

In this paper it is argued that corporal punishments cannot be justified as lawful sanctions. In addition, even based on traditional Islamic law under some conditions, it is possible to stop practicing corporal punishments. There are some other readings of Islamic law versus traditional one which suggest more ideas to reconcile human rights and Islamic concepts.

In the first four chapters, this paper examines the historical use of torture, various international and regional instruments that have been developed under international law to eliminate the use of torture, and the difficulties faced by the international community in its attempt to distinguish "torture" from other forms of cruel, inhuman or degrading 
treatment or punishment. Chapter five looks at the alternative approaches Islam has taken to the use of torture, while chapters six and seven look to Iran as an Islamic state. After a historical overview of the use of torture in Iran, the current human rights situation, and a look at contemporary Iranian laws and regulations with regard to the question of torture, an assessment of steps forward to eradicate torture in both theory and practice is presented. 


\section{French Abstract}

L'abolition de la torture et de l'utilisation de mesures correctives, toutes aussi cruelles, dégradantes et inhumaines les unes que les autres, est une des grandes aspirations des réformistes et activistes des droits humains depuis maintenant des siècles.

Des efforts globaux ont étés mis en place par des individus ainsi que des gouvernements nationaux, afin d'éradiquer l'utilisation de mesures punitives telle la torture. Malheureusement, trouver une définition unanimement acceptable sur le plan international, à savoir quels types d'activités constituent une torture, a été un obstacle majeur dans la guerre pour l'abolition de cette dernière. Est-ce que ce que l'on appelle torture se définit selon le but de l'acte? Au cœur du débat se situe une importante question, à savoir si le châtiment corporel est une forme de torture. Alors que ce type de châtiment est contraire aux législations internationales tel que « La convention contre la torture et autres peines ou traitements cruels, inhumains ou dégradants ", ou la «Convention contre la torture », toutes deux proposés pas les Nations Unies, plusieurs aspects du châtiment corporel demeurent acceptables dans le cadre de certaines traditions religieuses.

La loi traditionnelle Islamique, qui a banni la torture et autres peines ou traitements cruels, inhumains et dégradants lorsque utilisés dans le but d'obtenir dans l'immédiat une confession ou une information en particulier, en est un exemple. Par contre, un rigoureux châtiment corporel est accepté par la loi Islamique en d'autres circonstances. Il en résulte que certains états Islamiques, où les lois domestiques prennent leur principale source dans la loi traditionnelle Islamique, justifient l'utilisation de la torture en évoquant les traditions Islamiques : ils prétendent que le châtiment corporel est partie intégrante de la volonté de Dieu. Ces États ont tendance a considérer cela comme des sanctions légales, ainsi validées sous leur loi domestique. Dans la présente étude, l'Iran est regardé comme étant un de ces États.

Ce mémoire plaide que le châtiment corporel ne peut être justifié comme une sanction légale. Les quatre premiers chapitres examinent l'histoire de la torture, les différents instruments internationaux et régionaux qui ont étés développés sous la loi internationale afin d'éliminer l'utilisation de telles mesures punitives, ainsi que les difficultés auxquelles 
la communauté internationale doit faire face dans sa tentative pour distinguer la torture des autres formes de peine ou traitements cruels, inhumains ou dégradants.

Le chapitre cinq examine les approches alternatives prises par l'Islam en relation avec l'utilisation de la torture, alors que les chapitres six et sept examinent l'Iran en tant qu'État Islamique. Après un survol historique de l'utilisation de la torture en Iran, la situation actuelle des droits humains, et un regard sur les lois et régulations Iraniennes contemporaines en ce qui se rattache à la question de la torture, une évaluation des étapes pour l'éradication d'un tel châtiment, tant en théorie qu'en pratique, sont présentés. 


\section{Chapter 1: Introduction}

This thesis examines competing legal approaches and responses to the use of torture under international, domestic, and Islamic law. By focusing on recent events in Iran, it is motivated by my personal experience as a citizen, and a lawyer, in Iran.

When I was a child, during the last Shah's reign, I often heard stories of political prisoners. The common theme through these stories was one of torture as a tactic to obtain confessions from prisoners. I vividly remember TV broadcasts of political prisoners asking forgiveness from the Shah and the nation for the crimes they allegedly committed - crimes against national security, the royal family, the movement toward civilization, and the modernization process. ${ }^{1}$

My father, a political activist, tried to explain how unjust the regime was at the time. His primary reason for resistance to the regime was the violation of human rights, suffered by innocent people in custody all over Iran.

During the revolution, I had more reasons to condemn the Shah's regime than many of my classmates did. The Shah's regime, in my eyes, was a regime against humanity. There were times when I accompanied my father in the streets, and saw him participate in group protests, screaming revolutionary slogans. My father explained to me that human beings are respected in the eyes of Islam. In the new regime, the torture and the killing of innocent people would not happen.

When the Shah's regime was overthrown, the Islamic Republic came to power. This new regime aired programs on TV, showing the torture chambers in the Shah's prisons. In interviews, survivors explained what had happened to them. These were stories of violation of human rights, Islam and humanity.

At that time, I could never have imagined that one day I would come to write about the use of torture being practiced by religious torturers and alleged to be justified by Islamic rules.

Writing about torture is not easy, especially when one is writing about vast systemic

\footnotetext{
${ }^{1}$ For information about torture during the Shah reign see: Edward Abrahimian, Tortured Confessions: Prisoners and Public Recantations in Modern Iran, $1^{\text {ST }}$ ed. (Los Angeles: University of California Press, 1999) at 1.
} 
torture. Such a mandate is even harder when one is examining a religious state like Iran. On the one hand, the religious government may abuse Islamic teachings to justify its behavior - much oppression in Iran is believed to be God's will, and the people have no power, nor desire, to fight God. On the other hand, conditions after the revolution provided further excuses for the practice of torture. Conditions such as war, security operations, the fight against terrorism, or even the defense of human rights and of innocent people, were called upon to justify the use of torture. ${ }^{2}$

After the chaos of the revolution, many people found themselves in prison, deemed antirevolutionary group members, and incommunicado from family and friends who were left with no news of these prisoners. Thousands of innocent people, even children of 16 or 17 years old were tortured and executed without a fair trial. ${ }^{3}$

The Iranian system, like other systems of torture, seeks to destroy all evidence of its actions. ${ }^{4}$ Accurate information and writings have been scarce. Following a number of international human rights organizations' reports which brought cases to international attention, enough evidence exists that one of the worst torture systems in the world has been working in Iran for quite some time. The reports show that torture has been widely practiced, not only as a controversial form of punishment, but also as a mean of making the detainees confess to their alleged crimes. Many political activists have been subjected to torture, especially in recent years. ${ }^{5}$ From a legal perspective, knowledge of this terrible truth raises many questions:

- Are these actions legal under domestic law and international law?

- Are these actions in accordance with Islamic law?

- Is there a conflict between Islamic law and international law on the question of torture?

- If there is a conflict, is there any way to reconcile these competing forms of law?

\footnotetext{
${ }^{2}$ See below: sub-sections 6.3.1 \& 6.3.2.

${ }^{3}$ Ayatollah Montazeri, who was tortured in the Shah's prisons, wrote about some of them in his political memoirs. See; Ayatollah Hosein Ali Montazeri, "Political Memoirs" (Los Angles: Ketab Corp, 2001) at 198; online (Montazeri website): http://www.montazeri.ws/Farsi/Khaterat/FEHREST.HTM.

${ }^{4}$ Amnesty International, Kenya: Government fails to take action to stop torture, Al INDEX: AFR 32/04/97, 8 January 1997, News Service 247/96, online (Amnesty International website): http://web.amnesty.org/library/index/ENGAFR320041997.

${ }^{5}$ See below: sub-sections 6.3.3.
} 
This thesis is an attempt to respond to these questions. I approach these questions through three lenses: first through an international law perspective; second through Islamic jurisprudence (Shia faith) and the Iranian legal system in a comparative scale.

It is nearly universally understood that torture and other forms of cruel, inhuman or degrading treatment or punishment are unacceptable under International law. These practices are also offenses under Islamic law. Yet there is an apparent difference in how these two forms of law address issues of torture. In this paper I propose that the assumed difference in approach to torture taken by Islamic and international law lies in competing definitions, or understandings, of what constitutes torture. These competing definitions will be discussed in the paper.

By the letter of the law, torture is not allowed under Iranian domestic law, but in accordance with the Islamic understanding of torture. However, despite the Iranian government's claim that they apply Islamic law, there appears to be a gap between rhetoric and practice in Iran. Moreover, those Islamic regulations which are abused by hardliners ${ }^{6}$ and seemed to be in conflict with international human rights values can be

\footnotetext{
${ }^{6}$ A political Islamic fundamentalist group lead by the supreme leader, Ali Khamenei, who are holding absolute power in the country and control over the judiciary, police, army and media in Iran. Article 110 of Iranian Constitution: "Following are the duties and powers of the Leadership:

1. Delineation of the general policies of the Islamic Republic of Iran after consultation with the Nation's Exigency Council.

2. Supervision over the proper execution of the general policies of the system.

3. Issuing decrees for national referenda.

4. Assuming supreme command of the armed forces.

5. Declaration of war and peace, and the mobilization of the armed forces.

6. Appointment, dismissal, and acceptance of resignation of:

1. the fuqaha' on the Guardian Council.

2. the supreme judicial authority of the country.

3. the head of the radio and television network of the Islamic Republic of Iran.

4. the chief of the joint staff.

5. the chief commander of the Islamic Revolution Guards Corps.

6. the supreme commanders of the armed forces.

7. Resolving differences between the three wings of the armed forces and regulation of their relations.

8. Resolving the problems, which cannot be solved by conventional methods, through the Nation's Exigency Council.

9. Signing the decree formalizing the election of the President of the Republic by the people. The suitability of candidates for the Presidency of the Republic, with respect to the qualifications specified in the Constitution, must be confirmed before elections take place by the Guardian Council;, and, in the case of the first term [of the Presidency], by the Leadership;

10. Dismissal of the' President of the Republic, with due regard for the interests of the country, after the Supreme Court holds him guilty of the violation of his constitutional duties, or after a vote of
} 
interpreted in a way to reconcile them with international law, especially in some readings of Shia faith.

At the time of this writing (June 2004), human rights and specifically the use of torture are current and controversial topics in Iran. There is an ongoing campaign for human rights, with a focus on torture in Iran. Every day is a new day in such a campaign, and many changes take place in this day-to-day struggle. Despite of the fact that the reformists lost their majority in the parliament as of May 28, 2004 after being banned from running in the recent fake parliamentary election (Feb. 2004) by the fundamentalist Guardian Council, there are many student groups, human rights activists, lawyers and NGOs who are active in human rights promotion.

Hardliners are creating new cases by violating human rights through the torture of students, intellectuals, journalists, and other political activists, in prisons throughout Iran. The absolute majority of Iranians support reform in Iran as more than 20 millions voted Khatami in the last two presidential elections. They are fighting hardliners as they have been fighting for democracy and human rights for years. ${ }^{7}$ Helping such a campaign and the process of reform in Iran is one of my first goals in writing about torture in Iran. Another important goal of writing on this topic is to help future Iranian lawmakers to put an end to any kind of tacit acceptance of torture in the Iranian judicial system.

In writing this thesis, I have done my best to remain informed of all available facts, from officially provided international information, to memoirs of victims, to interviews and newspaper articles up to the end of July 2004.

the Islamic Consultative Assembly testifying to his incompetence on the basis of Article 89 of the Constitution.

11. Pardoning or reducing the sentences of convicts, within the framework of Islamic criteria, on a recommendation [to that effect] from the Head of judicial power. The Leader may delegate part of his duties and powers to another person.

${ }^{7}$ Such a campaign stopped one time by a coup designed by British and executed by Americans in 1953 resulted in overthrowing a democratic popular regime of Dr. Mossadegh and returning the escaped Shah back to power which was the beginning of his absolute tyranny and opening of torture chambers in Iran. Another attempt towards democracy happened in 1979 which resulted in a kind of religious tyranny called "VELAYATE FAGHIH" stipulated in the new Iranian constitution after a while. For more information about the 1953 coupe see: Stephan Kinzer, All The Shah's Men: An American Coup And The Roots of Middle East Terror, (john wiley \& sons inc., 2003); To know more about the 1979 revolution see: Sandra Mackey, The Iranians, Persia, Islam and the Soul of a Nation, (New York: Penguin Group Publishing, 1996) 271 - 301; also see: Edward Abrahimian, Khomeinism: Essays On The Islamic Republic, (Los Angeles: University of California Press, 1993). 


\section{Chapter 2: About torture in general}

This section will discuss the history of torture including its uses, arguments used as justification, and plights against its use.

\section{Section 2.1: A brief history of the use of torture, and of struggles against it}

Despite being a crime against humanity under international law, ${ }^{8}$ torture in various forms continues to be used in many parts of the world. ${ }^{9}$ The recognition of torture as a crime is arguably one of the most important achievements of modern history - and not one that was easily achieved. Here, I briefly review the history of torture in the world and attempts throughout history to eradicate its use. Uses of torture in Iran, and international responses to the use of torture are addressed in later sections. ${ }^{10}$

It is a reality that torture has been used in almost every part of the world at some time. ${ }^{11}$ The histories of the ancient civilizations of Persia, Rome, Greece, China and Egypt are replete with stories of the torture endured by detainees and prisoners. In Rome and Greece, slaves were not legal persons under the law, and as such were more frequently subject to torture than citizen of higher social classes. ${ }^{12}$ In some cases, and in certain crimes such as political conspiracy, everyone, without exception, could be subjected to torture. $^{13}$

In other parts of the world, torture has been a normal part of the judicial procedure, as the only known reliable means of obtaining evidence against the accused. ${ }^{14}$ Though common

\footnotetext{
${ }^{8}$ See below: section 3.5 .

${ }^{9}$ See: Amnesty International, Sad fact that fight against torture must continue in the 21st Century, AI INDEX: POL 30/006/2003, 25 June 2003, online amnesty international website: http://web.amnesty.org/library/index/engpol300062003

${ }^{10}$ See below: chapters $3 \& 6$.

${ }^{11}$ Nagan, Winston \& Atkins, Luice "The International Law of Torture: From Universal Proscription to Effective Application and Enforcement" (2001) 14 Harv. Hum. Rts. J.87 at 88 also see: Ingelse, Chris, infra note 17 at 23; also see: L. A. Parry, The History of Torture In England, $2^{\text {nd }}$ ed.(Montclair: Patterson Smith, 1975) at v.

${ }^{12}$ Ehsan Tabari, Torture and Hope, $1^{\text {st }}$ ed., (Tehran, 1957) at 63. Also see: L. A. Parry, supra note 11 at 26.

${ }^{13}$ L. A. Parry, supra note 11 at 26; also see: Lea, Henry Charles, Torture, $1^{\text {st }}$ ed. (Philadelphia: university of Pensylvania Press, 1973) at $\mathrm{x}$.

${ }^{14}$ Hussein Mirmohammad Sadeghi, "Crimes Against Humanity”, in Legal Ideas Review, faculty of Judicial Sciences and Administrative Judicial Services, Vol.9 at 81.
} 
the world over, torture was never uncontested. Campaigns against torture are as old as torture itself.

In Medieval Europe, torture was regularly used by the Church against those believed to be infidels. The Church officially authorized the use of torture in inquisition courts to persuade the accused to confess. ${ }^{15}$ Torture was often applied even after confession, and before execution, in order to gain additional information about other criminals. Many victims were brought into custody not because they were suspected of illegal activity, but simply because they were relatives of, or acquainted with, someone who had been arrested. $^{16}$

By the 17 th century, torture was less common in criminal proceedings, as judges were authorized to draw on logic in reaching a conviction. Gradually a system based on absolute evidential certainty regardless of the means used to obtain evidence was replaced by a new system based on the inner convictions of judges. This development provided an opportunity for abandoning the use of torture. ${ }^{17}$

At the beginning of the $17^{\text {th }}$ century, Edward Cooke criticized the use of torture during the trial of a terrorist who assassinated the British Prime Minster in 1628. After this case, torture as a method to extract information was declared illegal in England. ${ }^{18}$

In the 18th century, a new legal approach emerged due to the growth of humanitarian trends and values. This new approach eventually led to the emergence of a concept of human rights, based on the idea that everyone possesses an inherent dignity that must be respected. Moreover, some $18^{\text {th }}$ century commentators called to question the validity and reliability of confessions extracted by torture. ${ }^{19}$

Among the writers who made considerable efforts to abolish torture in Europe is Cesare Beccaria (1738-1794) who openly challenged this form of judicial abuse in Europe. In

\footnotetext{
${ }^{15}$ Jalalodin Ghiasi, Comparative Studies in Penal Law, $1^{\text {st }}$ ed., Vol. 1, (Tehran: Hawzah and university Research Center Press, 2001) at 74-75; also see: Hassan Dadban, Public Criminal Law, $1^{\text {st }}$ ed., (Tehran: University of Tabatabaee Press, 1998) at 67-68.

${ }^{16}$ For more information see: L. A. Parry, supra note 11 at xi; also see: Reza Mazlooman, Injustice Under Coverage of Law, in People's Right Magazine, No. 43, Year 11 (Tehran: 1975).

${ }^{17}$ Ingelse, Chris, the UN Committee Against Torture: An Assessment, $1^{\text {st }}$ ed. (London, Boston \& The Hague: Kluwer Law International, 2001) at 28.

${ }^{18}$ Mohammad Ali Ardebili, Public Criminal Law, $1^{\text {st }}$ ed., vol.1, (Tehran: Mizam Publishing, 2000) at 83.

${ }^{19}$ Ingelse, Chris, supra note 17 at 28.
} 
his famous book, On Crimes And Punishments, Beccaria presented several arguments against the use of torture. Based on a presumption of innocence, he argued that torture is a punishment imposed on a man whose crime is not certain:

"...either the crime is certain, or it is not; if it is certain, then no other punishment is suitable for the criminal except the one established by law, and torture is useless because the confession of the accused is unnecessary; if the crime is uncertain, one should not torment an innocent person, for, in the eyes of the law, he is a man whose misdeeds have not been proven. But I add, moreover, that one confuses all natural relationships in requiring a man to be the accuser and the accused at the same time and making pain the crucible of truth, as though the criterion of truth lay in the muscles and fibers of a poor wretch. ......If it is true that more men, whether from virtue or fear, respect the law rather than violate it, then the risk of torturing an innocent person should be considered all the greater when, other being equal, the probability is greater that a man has respected the law rather than despised it." 20

A second important point made by Beccaria was that torture left the victim with no choice but the quickest way to end the pain. In such a condition, he may confess if he knows that it will end his suffering. ${ }^{21}$

He emphasized that:

"... the outcome of torture, then, is a matter of temperament and calculation that varies with each man in proportion to his hardiness and his sensitivity, so that, by means of this method, a mathematician could solve the following problem better than a judge could: given the strength of an innocent person's muscles and the sensitivity of his fibers, find the degree of pain that will make him confess himself guilty of a given crime."

This idea was of course heeded long before Beccaria. In the early $18^{\text {th }}$ century, Roman lawyers commented that in some cases, torture results in entirely the opposite of what the torturer expected as victims of torture seek, most of all, an end to their pain. Victims of torture will often make statements they think will satisfy the prosecutor, whether these statements are true or false. $^{23}$

\footnotetext{
${ }^{20}$ Cesare Beccaria, On Crimes And Punishments, (Indianapolis: Hackett Publishing Company, 1986) at 29.

${ }^{21}$ Ibid at 32.

${ }^{22}$ Ibid.

${ }^{23}$ Lea, Henry Charles, Supra note 13 at x; also for more information see: L. A. Parry, supra note 11 at V.
} 
Gradually, criminal law was changed on compelling humanitarian grounds, as well as in response to such historical events as the French Revolution. ${ }^{24}$ The new ideas brought about by these changes influenced national codifications so that, by 1830 , torture had been abolished as a means of law enforcement in all European states. ${ }^{25}$

It was at that time that the famous French writer, Victor Hugo, proclaimed that "torture has ceased to exist." 26 Unfortunately, his proclamation was several hundred years premature. While torture was no longer an accepted part of law, its practice continued to exist, and was applied to certain groups of people, such as slaves and prisoners of war. ${ }^{27}$ In the early twentieth century, torture once again became an instrument of policy in the world. Kelman attributes this reemergence to the vulnerability of the modern state and its vast power over its citizens, as well as to emerging concepts such as security of states. ${ }^{28}$ Today, the legitimacy of states is closely tied to their denouncement of torture. To be acceptable in the eyes of the international community, even states that oppose the idea of universal human rights condemn torture, at least rhetorically. In the modern context, torture is not confined to any particular political system. It occurs in democracies as well as dictatorships, under civilian as well as military governments. ${ }^{29}$ Even in modern civilized countries that openly support human rights, one can find forms of torture; however, this is not easy to prove. ${ }^{30}$

\footnotetext{
${ }^{24}$ Ziaoddin Peimani, Judicial Evidences in French Law after Revolution, (Tehran: Ganje Danesh Publishing, 1977) at 73.

${ }^{25}$ Torture abolished in Ireland(1627), England (1640), Scotland (1708), France (1798), Russia (1801), and Germany (1831) cited in: L. A. Parry, Supra note 11 at 32.

${ }^{26}$ Cited in: Ingelse, Chris, supra note 17 at 1.

${ }^{27}$ Ingelse, Chris, supra note 17 at 30.

${ }^{28}$ Herbert C. Kelman, "The Social Context of Torture: Policy Process and Authority Structure" in Ronald D. Crelinsten \& Alex P. Schmid, ed. The Politics of Pain, Torturers and Their Masters (Oxford: West view Press, 1995) at 26.

${ }^{29}$ Ronald D. Crelinsten \& Alex P. Schmid, "Introduction: The Politics of Pain" in Ronald D. Crelinsten \& Alex P. Schmid, ed. The Politics Of Pain, Torturers And Their Masters (Oxford: Westview Press, 1995) at 33.

${ }^{30}$ For example see: Commission on Human Rights Resolution on Torture and other cruel, inhuman or degrading treatment or punishment, UN Doc. E/CN.4/RES/2002/38, online (UNHCHR website): http://www.unhchr.ch/huridocda/huridoca.nsf/(Symbol)/E.CN.4.RES.2002.38.En?Opendocument; also see: Theo Van Boven, Report of the Special Rapporteur on torture of the United Nations Commission on Human Rights, UNGA Doc. E/CN.4/2004/56, Sess. 60, http://ods-ddsny.un.org/doc/UNDOC/GEN/G03/173/27/PDF/G0317327.pdf?OpenElement
} 


\section{Section 2.2: Uses and purposes of torture}

Usually, torture is driven by states, most commonly, totalitarian states. It is just one crime among many other crimes they commit against their nationals. They abuse their exclusive power of punishment and legislation, as well as control over the police, and their unique position to justify crimes or hide them.

In the 18th century, Cesar Beccaria illustrated the purposes of using torture. At that time, he pointed to the following purposes:

"...make the accused confess his crime, or to discover his accomplices, or to resolve the contradictions into which he has fallen, or to find out other crimes of which he may be guilty but which he is not accused." 31

The definition of torture as outlined in Article 1 of the Convention Against Torture and Other Cruel, Inhuman or Degrading Treatment or Punishment ${ }^{32}$ points to the purposes of torture. In an indicative rather than inclusive list, torture is used in obtaining information or confession from the suspected perpetrator or a third person, punishing the suspected perpetrator, intimidating him or her or a third person, coercing him or her or a third person, and discriminatory reasons. ${ }^{33}$

While all possible purposes of torture cannot be counted, three major purposes for torture common in both ancient and modern times can be distilled: judicial, political and religious purposes. ${ }^{34}$

\section{Judicial purposes of torture}

To make an accused confess has been the major purpose of using torture. Confession could help the judge to convict the accused person based on his word. In early Europe, a "full proof" comprised of identical testimonies at least two different people was required to convict the accused. If a judge had just one reliable confession or testimony, part of his mandate was to obtain another confession to meet the "full proof". If a complementary

\footnotetext{
${ }^{31}$ Cesare Beccaria, supra note 20 at 29.

${ }^{32}$ Convention against Torture and Other Cruel, Inhuman or Degrading Treatment or Punishment, G.A. res. 39/46, [annex, 39 U.N. GAOR Supp. (No. 51) at 197, U.N. Doc. A/39/51 (1984)], entered into force June 26, 1987.

${ }^{33}$ See below: chapter 4 .

${ }^{34}$ See: Mohammad Ashouri, Criminal Procedural Law, Vol.1, (Tehran: Samt Publishing, 1996) at 29-30.
} 
confession was not given voluntarily, torture was considered the solution to obtain such a confession. $^{35}$

Today, due to the development of human rights regulations, judicial torture is not officially applied. The statements of accused persons under torture are invalid under international and most domestic law, ${ }^{36}$ though torture is still in use for extracting information and to make the accused confess in many countries. ${ }^{37}$

\section{Political purposes of torture}

In the modern day, politically motivated torture is most common. In its most frequent form, torture is applied to detainees during a judicial process in an effort to fight a potential threat to the state. This alleged threat provides rationale for the policy of torture. ${ }^{38}$ Here, torturers are defined as important professional forces that play a crucial or sometimes sacred role in protecting the state. Their victims are defined as enemies and a serious threat to the state and its people. ${ }^{39}$

If the legitimacy of those in power, in a totalitarian state, is challenged by an opposition group, the use of torture can be a serious threat to their power. Terrifying the members of this opposition can be a way to avoid the danger. ${ }^{40}$

Thus those in power may detain members of this group for one reason or another, and then torture them. They destroy the individual's personality in order to influence him, or to alter his future behavior, and also to let them and the others know that they are being tortured simply because they are members of that particular group. ${ }^{41}$

In this manner, the use of torture is not limited to foreign enemies of the state, but extends to domestic opposition to the state. Even if opposition groups have not yet started their operation, torture might be considered a preventive solution: The opposition group

\footnotetext{
${ }^{35}$ Ingelse, Chris, supra note 17 , at 26.

${ }^{36}$ International Covenant on Civil and Political Rights, 19 December 1966, 999 U.N.T.S. 171, Can. T.S. 1976 No. 47, 6 I.L.M. 368 (entered into force 23 March 1976).

${ }^{37}$ Theo Van Boven, supra note 30.

${ }^{38}$ Ronald D. Crelinsten \& Alex P. Schmid, supra note 29 at 27.

${ }^{39}$ Ibid at 28.

${ }^{40}$ Ann-Marie Bolin Pennegard, "Article 5", The Universal Declaration of Human Rights: A Common Standard of Achievement, ed. Asbojórn Eide \& Gudmundur Alfredsson (London: Martinus Nijhoff Publishers, 1999) at 121.

${ }^{41}$ Ibid.
} 
becomes aware that threatening the power will cost them too much. At the same time, individuals hesitate to come into contact with these opposition groups. Even without committing an action, simply being a member of an opposition group can be enough to make one guilty of a crime and subject to political torture. ${ }^{42}$

The situation is even worse for minority racial, ethnic, or religious groups such as Kurds in Turkey and Iran, Palestinians in Israel, and Shia people in Iraq when Saddam Hussein was in power. Members of these groups may be tortured just because they are a member of a particular religious or ethnic group, even when they are not involved in active opposition to the government. ${ }^{43}$ The case of Aksoy v. Turkey ${ }^{44}$ heard before the European Court of Human Rights is illustrative. At issue in the case was the torture of Askoy by Turkish officials, because he was a member of an ethnic group which opposed the Turkish secular government.

Often in cases of torture, the victim is forced to give a public interview in which he must confess his alleged actions, or those of his related group, and accept the accusations alleged by the government such as conspiracy against the nation and treason. This is used to mislead public opinion and provide positive propaganda for the regime. ${ }^{45}$

In some cases, prosecutors go further and try to make the political detainees confess particular actions, not in order to punish them, but simply to determine their political strategy, or to find evidence against another individual or group. ${ }^{46}$

\section{Religions purposes of torture}

Religion is a third motivating factor for the use of torture. Today, many punishments once rooted in religion are defined as torture. As I discuss later ${ }^{47}$, executing a religious

\footnotetext{
${ }^{42}$ Ronald D. Crelinsten \& Alex P. Schmid, supra note 29 at 27.

${ }^{43} \mathrm{Ibid}$.

${ }^{44}$ Aksoy v. Turkey, Judgment of the ECHR, 18 December 1996 [1996] IIHRL 110 (18 December 1996), online: http://www.worldlii.org/int/cases/IIHRL/1996/110.html

${ }^{45}$ For more information see Ervand Abrahimian, Tortured Confessions, supra note 1 at 142.

${ }^{46}$ In case of Dr. Sahabi and other members of Iranian Religious National Group, the Islamic regime tried to make them confess in order to use these confessions against reformists in executive power and parliament. For more information see: Report of the special representative of the Commission of Human Rights on the situation of human rights in the Islamic Republic of Iran, UNJAOR, $56^{\text {th }}$ Sess, UN Doc A/56/278, (Aug.2001) at 60 online: (UN website) http://www.unhchr.ch/huridocda/huridoca.nsf/AllSymbols/C6D20CD90B8EDF57C1256AD4003321F5/

${ }^{47}$ See below:section 4.2 .
} 
corporal punishment - such as stoning, amputation, or flogging - is no longer acceptable. Setting corporal punishments aside, in countries with extremist religious rulers such as is the case in Iran, a victim may be tortured as an attempt to change his views and turn him into a repentant person. The torturer assumes that the detainee is misled, and that his ideas must be corrected. Therefore, they should make him change his beliefs and become a good, religious person. ${ }^{48}$

In countries with a religious government who claim to represent God, such as Iran, the spiritual leader is seen as being appointed by God. As such, the spiritual leader's ideas cannot be wrong, and it is the followers' duty to provide proof to support the leader's idea. This can be done by obtaining a confession from the enemy. This confession shows that the spiritual leader realized the danger better than anyone else did. Also, proving his forecasts can be a good method of "demonstrating" spiritual powers and his connection to God. In this way, interrogators use torture to protect the integrity of their leader. The case of Saeed Eamami's wife is a very good example to show how such a practice may be implemented. ${ }^{49}$

\section{Section 2.3: Justifying the use of torture}

The practice of torture has been justified in various ways throughout history. In ancient times, in China, Europe and Greece, it seems that prosecutors were aware that torture violates human dignity. Torturing a free man could not be justified and was deemed as degrading and dehumanizing. However, this concept of human dignity was applied with a double standard: slaves were still subjected to torture because they were outside the dominant sector of society. As a result, prosecutors did not need to justify the use of torture against slaves. It also became acceptable over time to use torture against free men, but only if they committed a serious crime, such as conspiracy or treason. Then, the severity of the crime could justify the use of torture against them. ${ }^{50}$

Today, it is accepted that the use of torture is against what international law deems the

\footnotetext{
${ }^{48}$ See: Reza Afshari, Human Rights in Iran: the abuse of cultural relativism, (Philadelphia: University of Pennsylvania Press, 2001) at 48.

${ }^{49}$ See below: part 6.4.3.1.

${ }^{50}$ For more information see: Ingelse, Chris, supra note17at 32.
} 
values of human societies. Justifying torture is much more difficult than in ancient times, and at the same time, it seems that it is much more necessary to find excuses to justify it. Those states that practice torture systemically found it much easier to hide all evidence and deny the use of of torture, instead of giving justifications for what they are doing. When they cannot hide torture, they are usually forced to stop $\mathrm{it}^{51}$ or to find some excuses to justify it, at least, to convince the officials forced to deal with the torture process. ${ }^{52}$ All subjects of torture are defined as enemies, and the dehumanization of these enemies is the starting point for torturers who define themselves as important professionals with a crucial mandate to save the state. ${ }^{53}$

During war or in unstable political situations, when winning is the most important preoccupation, the possibility of practicing torture is higher. The situation of prisoners of war is worse than the situation of ordinary prisoners, because justifying the use of torture against them is much easier. As enemies, prisoners of war are tortured to obtain crucial information, and to prevent further operations that may threaten the security of state. ${ }^{54}$ There are also some concerns with regard to the anti-terrorist acts. According to the report of The UN Special Rapporteur on Torture, governments frequently fail to uphold legal safeguards against torture when dealing in anti-terrorist measures. ${ }^{55}$

Israel is a good example. In Israel, certain physical methods of interrogation which constituted torture were used by the General Security Service (GSS) against

\footnotetext{
${ }^{51}$ See: Amnesty International, When torturers can't hide, the torture stops, call to take action, released on June 26, 2004, online (Amnesty International website): http://web.amnesty.org/pages/stoptorture-260604action-eng

${ }^{52}$ For example: in case of Zahra Kazemi, the Iranian-Canadian journalist who was tortured to death in Iran's prison, Saeed Mortazavi, the General Prosecutor of Tehran, who is one of the suspects was denying torture and made a couple of stories to justify her death in prison but, at the same time, in every occasion he was stressing that Kazemi was spying for foreign countries while she arrested by the police. For more information see below: part 6.3.4.2.

${ }^{53}$ For example, in Iran intelligence ministry agents who are dealing vastly with torturing political detainees called themselves "Sarbazane Gomname Emame Zaman" which means "the unknown troops of the Imam Mahdi (the absent son of prophet Mohammad who is expected to be appeared one day to save people from oppression based on Shia beileif).

${ }^{54}$ That is why the very first steps to eradicate torture were the issue of prisoners of war, for more see below: section 3.1. ; also see: Wolfgang S. Heinz "The Military, Torture and Human Rights" in Ronald D.

Crelinsten \& Alex P. Schmid, ed. The Politics Of Pain, Torturers And Their Masters (Oxford: Westview Press, 1995) at 89.

${ }^{55}$ Theo Van Boven, supra note 30, para. 28.
} 
Palestinians. ${ }^{56}$ Israeli supporters claim that their special circumstances justify the use of torture. $^{57}$ Approximately 23,000 Palestinians between 1987 and 1994 were victims of torture. $^{58}$ Despite domestic and international concerns about the situation in Israel, the Israeli judiciary system supported GSS methods of interrogation. Finally, in September of 1999, the Israeli Supreme Court rejected the GSS interrogation practice, declaring that these methods are illegal and degrading. ${ }^{59}$ Despite the fact that most physical methods were outlawed, Human Rights Committee reports suggest that, for a long time after such a decision, the ruling effectively continued to permit the use of questionable tactics such as sleep deprivation and painful shackling. ${ }^{60}$

The United States government is also criticized for violating the human rights of prisoners of war detained in Iraq. It is admitted that "systemic and illegal abuse of detainees" has occurred in the Abu Ghraib facility (near Baghdad). Here, between August 2003 and February 2004, American soldiers "committed egregious acts and grave breaches of international law. ${ }^{61}$ The American government faces serious criticism by human rights organizations after photos of torturing detainees were released. ${ }^{62}$ US officials accused some individuals of committing such crimes, and denied suspicion that the tortures were systematically ordered incidents. ${ }^{63}$

\footnotetext{
${ }^{56}$ See: Amnesty International Report, Israel Supreme Court To Rule on Torture and the Holding of Hostages, AI Index: MDE 15/39/99, 25 MAY 1999, online(AI Website): http://web.amnesty.org/library/index/ENGMDE150391999; also see: Written statement submitted by

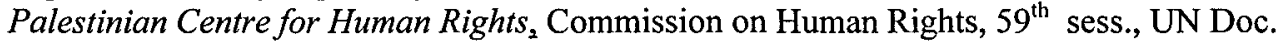
E/CN.4/2003/NGO/200, 17 March 2003, Para 4.

${ }^{57}$ Special Report on Israel, UNCAT, $18^{\text {th }}$ Sess, $296^{\text {th }} \mathrm{mtg}$, UN Doc. CAT/C/SR.296, (1997) at 6-7, 34-37.

${ }^{58}$ Cited in: Cathrine M. Grosso, "International Law in the Domestic Arena: the case of torture in Israel" (2000) 87 Iowa L. Rev. 305 at 312.

${ }^{59}$ The Public Committee Against Torture in Israel v The Government of Israel et al, Case no. HCJ 5100/94, Israeli Supreme Court sitting as High Court of Justice, Sep. 6, 1999, online: http://www.stoptorture.org.il/eng/images/uploaded/publications/18.doc

${ }^{60}$ For example see: Written statement submitted by Palestinian Centre for Human Rights, supra note 56.

${ }^{61}$ Antonio M. Taguba, Article 15-6 Investigation of 800th Military Police Brigade: US Army Report on Abuse of Iraqi Prisoners, May 5, 2004, online (CBC Website): $\underline{\text { http://www.cbc.ca/news/background/iraq/pdf/taguba report.pdf }}$

${ }^{62}$ For example see: Amnesty International, An Open Letter To President George W. Bush on the question of Torture and Cruel, Inhuman or Degrading Treatment, AI Index: AMR 51/078/2004, 7 May 2004, online (AI Website): http://web.amnesty.org/library/Index/ENGAMR510782004

${ }^{63}$ For example Donald Rumsfeld, Secretary of Defense in his testifies to the U.S. Senate Armed Services Committee which held a hearing on the treatment of Iraqi Prisoners says: “... It's important for the American people and the world to know that while these terrible acts were perpetrated by a small number of U.S. military, they were also brought to light by the honorable and responsible actions of other military
} 
The dangerous idea that torture is necessary to save lives, particularly in terrorist attacks, has found itself more resonant after the terrorist attacks of September 11th. Some commentators such as Mr. Alan Dershowitz submit that the new global situation justifies the use of torture. ${ }^{64}$ To convince his audience, he uses the example of a ticking-bomb. Suppose that there is a ticking bomb installed in a crowded area, and at this time, you have a suspect in your custody who knows where the bomb is, and when it will explode. You know that torture may induce the bomber to give useful information that will save many lives. Is it then illegitimate if you use torture only against one individual to save a great number of lives? Dershowitz also added that it ought to be done openly, with accountability, and with the approval by the president of the United States, or by a Supreme Court justice. ${ }^{65}$

Such an authorization is would be a dramatic step backwards in the global advancement of human rights. This type of justification is not so different from those reasons advanced to support the practice of torture throughout history. How far could this reasoning be extended? The prohibition of torture was not achieved overnight. Suggesting its qualified reinstatement can be considered as negligence with respect to human dignity. ${ }^{66}$ The prohibition of torture is one of the basic, absolute prohibitions in international law. It exists in times of peace, as well as in times of war.

personnel." ; See: Rumsfeld Testifies Before Senate Armed Services Committee, Washington Post, Friday, May 7, 2004, online (Washington Post Website): http://www.washingtonpost.com/wp-dyn/articles/A85752004May7.html

${ }^{64}$ Dershowitz Alan: Torture could be justified, CNN, Monday, March 3, 2003 online: http://www.cnn.com/2003/LAW/03/03/cnna.Dershowitz/

${ }^{65}$ Dershowitz Alan, A choice among evils, Globe and Mail, Wednesday, March 5, 2003 at Al7 online: http://www.globeandmail.com/servlet/ArticleNews/TPStory/LAC/20030305/CODERSH/TPComment/Top $\underline{\text { Stories }}$

${ }^{66}$ Ingelse, Chris, supra note 17 at 23. 


\section{Chapter 3: Torture in International Law}

States are the most important - and powerful - entities within which people are organized. There must be some guarantees to protect individuals against a state's possible intention to use torture. Responding to this need, there have been some efforts in international law. Inherent human dignity has been at the core of human rights debates. Torture and other cruel, inhuman or degrading treatment or punishments are threats to the dignity of victims. As such, the struggle against torture has become a central concern of human rights law.

Under international law, there have been multiple attempts to define and restrain the use of torture. The first international legal text specifically outlawing "torture" was the 1948 Universal Declaration of Human Rights (Article 5). The first treaty prohibiting torture the European Convention on human rights (Article 3) - was adopted soon afterward[s], in 1950. In 1984, the United Nations Convention Against Torture became the first binding international instrument exclusively dedicated to the struggle against one of the most serious and pervasive human rights violations of our time.

Today, most general human rights conventions, at both regional and international levels, address the issue of torture and ill-treatment of persons. ${ }^{67}$ They declare that torture is prohibited, even during emergencies or armed conflicts. ${ }^{68}$ The dedication of international human rights law to outlawing such acts is also evidenced by the existence of instruments dedicated to the prevention of torture. ${ }^{69}$

The United Nations and some other important regional institutions also have specialized bodies responsible for the prevention of torture. The most important of these international as well as regional efforts, which have been aimed to ban and illegalize torture, will next be surveyed.

\footnotetext{
${ }^{67}$ e.g.: Article 7 of the Covenant on civil and political rights (ICCPR), 19 December 1966; Article 37(a) of the Convention on the rights of the child (CRC), 20 November 1989; Article 5(2) of the American Convention on human rights (ACHR), 22 November 1969; Article 3 of the (European) Convention for the protection of human rights and fundamental freedoms (ECHR), 4 November 1950; Article 5 of the African Charter on human and peoples' rights, 26 June 1981.

${ }^{68}$ Article 4(2) ICCPR, Article 15(2) ECHR, Article 27(2) ACHR.

${ }^{69}$ European Convention for the prevention of torture and inhuman or degrading treatment or punishment, 26 November 1987; Inter-American Convention to prevent and punish torture, 9 December 1985.
} 


\section{Section 3.1: The Hague Conventions}

The widespread prohibitions on torture in human rights law is the result of the great efforts made by human rights activists over many years. Perhaps the first international effort to ban torture was during the two Peace Conferences in The Hague in 1899 and 1907. These two conferences drafted principles for the humane treatment of prisoners of war and civilian population. ${ }^{70}$

The Martens Clause ${ }^{71}$ appears in the preamble to the 1899 Hague Convention (II) and applies to the laws and customs of war on land. ${ }^{72}$ The Clause was based upon and took its name from a declaration read by Professor von Martens, the Russian delegate at the Hague Peace Conference 1899. Torture violates the Martens Clause as it is against the "dictates of the public conscience."

Article 4 of the annexes to the Hague Conventions on the Laws and Customs of War on Land of $1899^{73}$ and $1907^{74}$ states that:

"Prisoners of war are in the power of the hostile Government, but not in that of the individuals or corps who captured them. They must be humanely treated. All their personal belongings, except arms, horses, and military papers remain their property."

Without referring explicitly to "torture," this Article emphasizes humane treatment,

\footnotetext{
${ }^{70}$ First Peace Conference at The Hague: Signed - 29 July 1899; entry into force - 4 September 1900. Second Peace Conference at The Hague: Signed - 18 October 1907; entry into force -26 January 1910 , reprinted in A. Roberts and R. Guelf, Documents on the Laws of War, 2nd ed., Clarendon Press, Oxford, 1989, at 45, available online (Yale law school library website): http://www.lib.byu.edu/ rdh/wwi/hague.html

${ }^{71}$ Martens-clause: "Until a more complete code of the laws of war has been issued, the High Contracting Parties deem it expedient to declare that, in cases not included in the Regulations adopted by them, the belligerents remain under the protection and the rule of the principles of the law of nations, as they result from the usages established among civilized people, from the laws of humanity, and the dictates of the public conscience" cited: Ingelse, Chris, supra note 17 at 38.

${ }^{72}$ Preamble of Convention with respect to the laws and Custums of war on land (HAGUE, II) (29 July 1899) para. 10. For more information see: Rupert Ticehurst, The Martens Clause and the Laws of Armed Conflict, in "International Review of the Red Cross", no 317, 30 March 1997, 125-134, at 125; see also: C. Greenwood, "Historical Development and Legal Basis", in Dieter Fleck (ed.), The Handbook of Humanitarian Law in Armed Conflicts, (Oxford: Oxford University Press, 1995) at 28.

${ }^{73}$ Annex to the Convention with respect to the laws and Custums of war on land (HAGUE, II) (29 July 1899), SECTION I, CHAPTER II, available online (Yale law school library website): http://www.yale.edu/lawweb/avalon/lawofwar/hague02.htm\#art4

${ }^{74}$ Annex to the Convention with respect to the laws and Custums of war on land (HAGUE, IV) (18 Oct. 1907), SECTION I, CHAPTER II, available online (Yale law school library website): http://www.yale.edu/lawweb/avalon/lawofwar/hague04.htm\#art4
} 
clearly excluding torture. ${ }^{75}$

\section{Section 3.2: Geneva Conventions}

Article 3 is common to the four Geneva Conventions ${ }^{76}$ of 1949 , and includes on the list of minimum standards to be observed by all parties even in non-international armed conflicts, a prohibition of "[v]iolence to life and person, in particular murder of all kinds, mutilation, cruel treatment and torture". ${ }^{77}$ Moreover, torture and inhuman treatment are

\footnotetext{
${ }^{75}$ A prohibition of torture can also be deduced from other Articles, including 44 and 46; see M. Cherif Bassiouni, "An appraisal of torture in international law and practice: The need for an International Convention for the prevention and suppression of torture", Revue internationale de droit pénal, Vol. 48, 1977, Nos. 3 and 4, at 71.

${ }^{76}$ Geneva Convention (I) for the Amelioration of the Condition of the Wounded and Sick in Armed Forces in the Field. Geneva, 12 August 1949. available online:

http://www.icrc.org/ihl.nsf/7c4d08d9b287a42141256739003e636b/fe20c3d903ce27e3c125641e004a92f3?

OpenDocument

Geneva Convention (II) for the Amelioration of the Condition of Wounded, Sick and Shipwrecked Members of Armed Forces at Sea. Geneva, 12 August 1949. This Convention covered the treatment of wounded, sick and shipwrecked members of armed forces at sea. It was written and adopted at the diplomatic conference held at Geneva from April 21 to August 12, 1949, for the purpose of revising the Xth Hague Convention of October 18, 1907 for the Adaptation to Maritime Warfare of the Principles of the Geneva Convention of 1906. full text is available online: http://www.icrc.org/ihl.nsf/7c4d08d9b287a42141256739003e636b/44072487ec4c2131c125641e004a9977? OpenDocument

Geneva Convention (III) relative to the Treatment of Prisoners of War, Adopted on 12 August 1949 by the Diplomatic Conference for the Establishment of International Conventions for the Protection of Victims of War, held in Geneva from 21 April to 12 August, 1949. Entered into force 21 October 1950, available online: http://wikisource.org/wiki/Third_Geneva Convention\#Article 3
}

Geneva Convention (IV) ("GCIV") relates to the protection of civilians in time of war and under any occupation by a foreign power. This should not be confused with the more common Third Geneva Convention which deals with the treatment of Prisoners of war. Geneva Convention Relative to Protection of Civilian Persons in Time of War, 75 U.N.T.S. 287, entered into force Oct. 21, 1950, onnline (UNHCRH web site): http://www.unhchr.ch/html/menu3/b/92.htm

${ }^{77}$ Article 3: "In the case of armed conflict not of an international character occurring in the territory of one of the High Contracting Parties, each Party to the conflict shall be bound to apply, as a minimum, the following provisions:

(1) Persons taking no active part in the hostilities, including members of armed forces who have laid down their arms and those placed hors de combat by sickness, wounds, detention, or any other cause, shall in all circumstances be treated humanely, without any adverse distinction founded on race, color, religion or faith, sex, birth or wealth, or any other similar criteria.

To this end, the following acts are and shall remain prohibited at any time and in any place whatsoever with respect to the above-mentioned persons:

(a) violence to life and person, in particular murder of all kinds, mutilation, cruel treatment and torture;

(b) taking of hostages;

(c) outrages upon personal dignity, in particular, humiliating and degrading treatment; (d) ...." 
among grave breaches to the four Geneva Conventions of $1949 .^{78}$

Similarly, the second Protocol, ${ }^{79}$ added to the Geneva Conventions of 12 August 1949, prohibits "violence to the life, health and physical or mental well-being of persons, in particular. . . cruel treatment such as torture, mutilation or any form of corporal punishment" 80 .

The Third Geneva Convention obliges State Parties and their authorities to treat prisoners of war of international armed conflicts humanely at all times, and to respect their persons in all circumstances. ${ }^{81}$ The Fourth Convention prohibits acts of violence against and the torture of protected civilians in times of war. ${ }^{82}$

Finally, Article 75 of Protocol $\mathrm{I}^{83}$ extends this prohibition to all persons in such situations, and clarifies that "torture of all kinds, whether physical or mental" is absolutely prohibited.

\section{Section 3.3: UN efforts against torture}

In late 1945, leaders of the world's nations met in San Francisco to form the United Nations. Inspired by the great South African pre-apartheid leader Field-Marshall Smuts, they included in the preamble to the Charter of the $\mathrm{UN}^{84}$ an important reference to human rights. The relevant part of the preamble states:

"We the peoples of the United Nations [are] determined to reaffirm faith in fundamental human rights, in the dignity and worth of the

\footnotetext{
${ }^{78}$ Article 50 of the Geneva Convention (I), Article 51 of the Geneva Convention (II), Article 130 of the Geneva Convention (III) and Article 147 of the Geneva Convention (IV).

${ }^{79}$ Protocol Additional to the Geneva Conventions of 12 August 1949, and relating to the Protection of Victims of Non-International Armed Conflicts (Protocol II), 8 June 1977. available online: http://www.icrc.org/ihl.nsf/7c4d08d9b287a42141256739003e636b/d67c3971bcfflc10c125641 e0052b545? OpenDocument

${ }^{80}$ Article 4, para. 2(a) of the 1977 Protocol Additional to the Geneva Conventions of 12 August 1949, and relating to the protection of victims of non-international armed conflicts (Protocol II).

${ }^{81}$ Articles 13 and 14 of the Third Geneva Convention relative to the treatment of prisoners of war of 12 August 1949.

${ }^{82}$ Articles 27 and 32 of the Fourth Geneva Convention relative to the protection of civilian persons in time of war of 12 August 1949.

${ }^{83}$ Supra note 79.

${ }^{84}$ Charter of the United Nations, June 26, 1945, 59 Stat. 1031, T.S. 993, 3 Bevans 1153, online: UN website, http://www.un.org/aboutun/charter/
} 
human person, in the equal rights of men and women and of nations large and small"

Subsequent UN documents have upheld this spirit of fundamental human rights, and also made more specific references to torture. Some of these are as follows.

\section{Sub-section 3.3.1: Universal Declaration of Human Rights (UNDHR)}

The Universal Declaration of Human Rights (UDHR) ${ }^{85}$ was adopted on December 10, 1948 by the General Assembly of the United Nations with 48 states voting in favor and eight abstaining, as the first set of universal standards of human rights. ${ }^{86}$

In adopting this document, the international community accepted that every individual has minimum rights to be observed by the states. ${ }^{87}$ Moreover, it was accepted that observance of human rights is a collective responsibility of the member states. ${ }^{88}$

Torture, as a grave breach to human dignity was among other important issues discussed in this Declaration. Article 5 of the Declaration reads: "No one shall be subjected to torture or to cruel, inhuman or degrading treatment or punishment"

This article represents the first direct effort towards codifying an international ban on torture. It became the basis for universal and regional treaties against torture to come. These concepts created a new vision of the issue. Inhuman punishments such as torture were brought to the attention of the world. ${ }^{89}$ Article 5 was adopted unanimously by the General Assembly, ${ }^{90}$ and did not give rise to a great deal of debate during the assessment

\footnotetext{
${ }^{85}$ Universal Declaration of Human Rights, GA Res. 217(III), 3d Sess. Supp. No.13, UN Doc. A/810 (1948) online: United Nations Home Page http://www.un.org/Overview/rights.html .

${ }^{86}$ Henry J. Steiner \& Philip Alston, International Human Rights in Context, 2 ed. (New York: Oxford University Press, 2000) at 138.

${ }^{87}$ See Article 2 of the UDHR; supra note 85.

${ }^{88}$ The preamble of the UDHR stipulates that: “...Whereas Member States have pledged themselves to achieve, in co-operation with the United Nations, the promotion of universal respect for and observance of human rights and fundamental freedoms, ..."

${ }^{89}$ Hans Danelius, "Article 5" in The Universal Declaration of Human Rights: A Commentary, ed. Asbojórn Eide, Gudmundur Alfredsson and others (Norway: Scandinavian University Press, 1992) at 102.

${ }^{90}$ The Universal Declaration as a whole was adopted by 48 votes for, 0 against and 8 abstentions; cited from: Chris Ingelse, supra note 17 at 48; for more information about UDHR see: Bahman Aghaee, Human Rights Culture, ed. 1 (Tehran: Ganje Danesh Publishing, 1997) at 15; Mohammad Jafar Pooyandeh, Universal Declaration of Human Rights and Its History, ed.1 (Tehran: Nei Publications, 1998) at 127.
} 
of the two drafts submitted to the UN Secretariat. ${ }^{91}$

Sub-section 3.3.2: International Covenant on Civil and Political Rights (ICCPR) The 1966 International Covenant on Civil and Political Rights ${ }^{92}$ was one of the two principal treaties ${ }^{93}$ drafted and amended in the UN Commission on Human Rights ${ }^{94}$, the Third Committee of the UN General Assembly and the UN General Assembly where they were approved. They entered into force after achieving the number of necessary ratifications a decade later. ${ }^{95}$

Article 7 of the ICCPR goes beyond the text of the UDHR:

$$
\begin{aligned}
& \text { "No one shall be subjected to torture or to cruel, inhuman or } \\
& \text { degrading treatment or punishment. In particular, no one shall be } \\
& \text { subjected without his free consent to medical or scientific } \\
& \text { experimentation" }
\end{aligned}
$$

The first part of the article is identical to article 5 of the UDHR. This article was approved without any serious debate, and no debate occurred over the definition of torture and cruel, inhuman or degrading treatment or punishment.

According to article 4 of the ICCPR, the ban on torture is defined as "notstandsfest", so even a state of emergency cannot justify the practice of torture.

${ }^{91}$ Jalil Omidi, The Rights of Accused Person in the courts according to International and regional documents of Human Rights, Tehran Bar Assocoiation Review, New Series vol.2, Jan. 2001, at 43.

${ }^{92}$ International Covenant on Civil and Political Rights, supra note 36.

${ }^{93}$ The other treaty is "The International Covenant on Economic, Social and Cultural Rights (ICESCR)" Adopted and opened for signature, ratification and accession by General Assembly res. 2200A (XXI), 16 December 1966, entry into force 3 January 1976, in accordance with article 27.

${ }^{94}$ The United Nations Commission on Human Rights, composed of 53 States, meets each year in regular session in March/April for six weeks in Geneva. Over 3,000 delegates from member and observer States and from non-governmental organizations participate. The Office of the United Nations High Commissioner for Human Rights, a part of the United Nations Secretariat, provides secretariat services to the Commission on Human Rights and to other human rights meetings. The mandate of this Office derives from Articles 1, 13 and 55 of the Charter of the United Nations, the Vienna Declaration and Program of Action and the General Assembly resolution 48/141 of 20 December 1993, by which the Assembly established the post of United Nations High Commissioner for Human Rights.

${ }^{95}$ Supra note 86at 139. 
The ICCPR also has two Optional Protocols. The first ${ }^{96}$ allows individuals (not just states) to lodge complaints of human rights violations with the UN as a supervisory mechanism. The second is designed to eliminate the death penalty.

Based on article 5 of the Optional Protocol ${ }^{97}$, the Human Rights Committee shall consider the individuals' complaints, but its statements, which will be given according to the first Optional Protocol, are not binding.

Article 7 is not the only article in the ICCPR that contains a provision related to the issue of torture. Articles 9 and 10, also, are relevant to the ban on torture and cruel, inhuman or degrading treatment or punishment. Article 9 states: "Every one has the right to liberty and security of person."

The first paragraph of article 10 states:

"All persons deprived of their liberty shall be treated with humanity and with respect for the inherent dignity of the human person."

These two articles are relevant to the matter of detention and the conditions of detention. Articles 9 and 10 are not covered by article 4 of the ICCPR ${ }^{98}$, so they may be limited by a state of emergency. Yet even in this case, article 7 supports that detainees can never be denied these rights. ${ }^{99}$

${ }^{96}$ Optional Protocol to the International Covenant on Civil and Political Rights, G.A. Res. 2200A (XXI), 21 U.N. GAOR Supp. (No. 16) at 59, U.N. Doc. A/6316 (1966), 999 U.N.T.S. 302, entered into force March 23, 1976.

${ }^{97}$ Article 5: "1. The Committee shall consider communications received under the present Protocol in the light of all written information made available to it by the individual and by the State Party concerned. 2. The Committee shall not consider any communication from an individual unless it has ascertained that: (a) The same matter is not being examined under another procedure of international investigation or settlement; (b) The individual has exhausted all available domestic remedies. This shall not be the rule where the application of the remedies is unreasonably prolonged. 3. The Committee shall hold closed meetings when examining communications under the present Protocol. 4. The Committee shall forward its views to the State Party concerned and to the individual."

${ }^{98}$ Article 4 of the ICCPR states: "1. In time of public emergency which threatens the life of the nation and the existence of which is officially proclaimed, the States Parties to the present Covenant may take measures derogating from their obligations under the present Covenant to the extent strictly required by the exigencies of the situation, provided that such measures are not inconsistent with their other obligations under international law and do not involve discrimination solely on the ground of race, colour, sex, language, religion or social origin. 2. No derogation from articles 6, 7, 8 (paragraphs I and 2), 11, 15, 16 and 18 may be made under this provision."

${ }^{99}$ Ingelse, Chris, supra note 17 at 52. 
Iran signed the ICCPR on April 8, 1968 and ratified it in May $1975 .{ }^{100}$ After the Islamic Revolution, the new Islamic government did not reject the ICCPR. However, there was a debate among some Iranian lawyers as to its compatibility with Islamic teachings. ${ }^{101}$

\section{Part 3.3.2.1: The UN Human Rights Committee}

The ICCPR has a monitoring body that may review complaints. State parties are required (article 40) to report to the Human Rights Committee on implementation of the ICCPR, and to submit reports on particular topics on request.

The Committee of Human Rights considers each report in its sessions. ${ }^{102}$ The Committee may hear claims from individuals whose rights and freedoms have been violated by a State party to the Optional Protocol to the ICCPR ${ }^{103}$. One of the clearest signs of progress in human rights is that as of May 3, 2004, the Committee has heard 1279 complaints from individuals involving 104 state parties. ${ }^{104}$

The Committee, based on article 40 of the ICCPR, may provide the state parties with General Comments. On the question of torture, the committee in one of its General Comments, ${ }^{105}$ notes that it is the duty of state parties to afford everyone protection through legislative and other measures against the acts prohibited by article 7 of the

\footnotetext{
${ }^{100}$ Hussein Mehrpoor, Human Rights in international documents and the position of the Islamic Republic of Iran, (Tehran: Ettelaat Publications, 1995) at 49.

${ }^{101}$ Hussein Mehrpoor, ibid at 50-51.

${ }^{102}$ For example, the Committee considered reports from Finland, Poland, Benin, Albania and Kenya in its last session ( $82^{\text {nd }}$ session, 18 October-5 November 2004 in Geneva). See online (UNHCHR website): http://www.unhchr.ch/html/menu2/6/hrc/hrcs80.htm\#82

${ }^{103}$ Supra note 96.

${ }^{104}$ Statistical survey of individual complaints dealt with by the Human Rights Committee under the Optional Protocol to the International Covenant on Civil and Political Rights, Released by the Office of the High Commissioner for Human Rights, 3 May 2004, online (UNHCHR Website): http://www.unhchr.ch/html/menu2/8/stat2.htm; for more information about how the Committee hear the individual cases see: Selected Decisions of the Human Rights Committee Under the Optional Protocol, Vol.3, (Thirty-third to thirty-ninth sessions), UN Doc. CCPR/C/OP/3, (Geneva: United Nations Publications, 2002) available online (UNHCHR website): http://www.unhchr.ch/html/menu6/2/sdecisions.ttf ${ }^{105}$ ICCPR general comment no.20, Human Rights Committee, Sess. 44, 10/03/92, Para. 12., online (UNHCHR website): http://www.unhchr.ch/tbs/doc.nsf/385c2add1632f4a8c12565a9004dc311/6924291970754969c12563ed004c 8ae5?OpenDocument
} 
ICCPR. This Committee insists that the ban on torture must be extended to corporal punishments.

As Iran will later be the focus of this paper, it is of interest that the Iranian government delivered its first report to the Human Rights Committee on August 9, 1977. This report was refused as it was not in accordance with the standards. The supplementary report was delivered on May 29, 1978, only a few months before the Islamic revolution. ${ }^{106}$

The second report was delivered in July of 1982 by the Islamic Iranian government. It was under assessment in numerous sessions in the Human Rights Committee, and was also rejected due to the fact that particular standards were not followed in preparing the report. The second supplementary report was delivered ten years later on May 22, 1992. ${ }^{107}$

\section{Part 3.3.2.2: Special Rapporteur on Torture}

Based on the decision of the United Nations Commission on Human Rights Resolution $1985 / 33,{ }^{108}$ the Commission appoints an expert as Special Rapporteur, to examine questions relevant to torture. The mandate of the Special Rapporteur covers all countries, regardless of whether a State has ratified the Convention Against Torture and Other Cruel, Inhuman or Degrading Treatment or Punishment.

The mandate of the Special Rapporteur on Torture is a combination of various duties. Among these are transmitting urgent appeals to States with regard to individuals reported to be at risk of torture, communications on past alleged cases of torture; undertaking factfinding country visits; and submitting annual reports to the Commission and the General Assembly. ${ }^{109}$

The Special Rapporteur can act when the facts in question come within the scope of more

\footnotetext{
${ }^{106}$ Hussein Mehrpoor, supra note 100 at 51.

${ }^{107}$ Ibid at 52.

${ }^{108}$ UN Commission on Human Rights Resolution, UN Doc E/CN.4/RES/1985/33,13 March 1985.

${ }^{109}$ for more information on the mandate and methods of work of the Special Rapporteur see; Report of the Special Rapporteur on the question of torture, submitted in accordance with Commission resolution 2002/38, UN Doc. E/CN.4/2002/68, 17 Dec. 2002, Sess. 59, at 3, online (UN website): http://ods-ddsny.un.org/doc/UNDOC/GEN/G02/160/49/PDF/G0216049.pdf?OpenElement
} 
than one mandate of the Commission with no need to exhaust domestic remedies. ${ }^{110}$ The Special Rapporteur may also decide to approach other thematic mechanisms and country rapporteurs with a view to sending joint communications or seeking joint missions. ${ }^{111}$

The Special Rapporteur gives recommendations via his reports for the prevention and investigation of torture. These recommendations are a good basis for the resolutions made by the UN Commission on Human Rights. ${ }^{112}$ The Commission recommends all states to respect the absolute ban on torture with regard to the UN Declaration on the Protection of All Persons from Being Subjected to Torture and Other Cruel, Inhuman or Degrading Treatment or Punishment as well as the recommendations made by the Special Rapporteur. ${ }^{113}$ The Special Rapporteur may arrange some visits to the countries concerned in order to investigate torture as the most hidden human rights violation. ${ }^{114}$ Mr. Theo Van Boven, an expert from the Netherlands was appointed as the third Special Rapporteur in 2001. Before him, Nigel S. Rodley from the United Kingdom (1993-2001) and Peter Kooijmans from the Netherlands (1985-1993) carried out these mandates. Turning attention again to Iran, the question of torture has been pointed to in many of the reports issued by Special Rapporteurs on torture. ${ }^{115}$

Sub-section 3.3.3: Standard Minimum Rules for the Treatment of Prisoners A General Assembly Resolution on Standard Minimum Rules for the Treatment of

\footnotetext{
${ }^{110}$ Supra note 108.

${ }^{111}$ In case of Iran, there has been a very close cooperation between the Special Representative on the situation of Human Right in Iran and the Special Rapporteur on Torture. For example see: Nigel S. Rodley, Report of the Special Rapporteur, UN Doc. E/CN.4/1998/38/ADD.1, Sess. 54 $4^{\text {th }}, 24$ Dec. 1997 at 42.

${ }^{112}$ For example see: Nigel Rodley, Torture and other Cruel, Inhuman and Degrading Treatment or Punishment, Report of the Special Rapporteur, UN Doc. E/CN.4/2002/76, 27 Dec. 2001, Sess. $58^{\text {th }}$, at 5.

${ }^{113}$ For example see: Commission on Human Rights resolution, supra note 30.

${ }^{114}$ The former Special Rapporteur on Torture of the UN Human Rights Commission, Peter Kooijmans, believes that the duty to prevent torture is of paramount importance as violations are often hidden. He has accurately called torture the most intimate human rights violation, as it takes place in isolation and is very often inflicted by a torturer who remains anonymous to the victim and who regards the victim as a faceless object. Visits to places of detention help to eliminate this anonymity and are therefore very effective in preventing torture. Such visits also make it possible to identify situations conducive to torture and initiate appropriate measures to reduce the risk of such acts. See: Peter Koojimans, Torture and other Cruel, Inhuman and Degrading Treatment or Punishment, Report of the Special Rapporteur, 21 December 1991, UN Doc. E/CN.4/1992/17, para. 277.

${ }^{115}$ For example the last report has mentioned many cases of torture in Iran including Zahra Kazemi's case: Theodor Van Boven, supra note 30, para. 806 - 835.
} 
Prisoners ${ }^{116}$ was adopted at the First United Nations Congress on the Prevention of Crime and the Treatment of Offenders, held at Geneva in 1955, and approved by the Economic and Social Council Resolutions 663 C (XXIV) of 31 July 1957 and 2076 (LXII) of 13 May 1977. These resolutions extended the applicability of these rules to persons detained without charge, that is, in places other than prisons.

As it is mentioned at the outset of the Minimum Standards, the rules are not intended to describe in detail a model system of penal institutions. They are a set of rules that seem to be acceptable by civilized people in treatment of prisoners. They also represent a kind of general consensus of contemporary thought and the essential elements of the most adequate systems of today. The document contains some rules about registering prisoners, personal hygiene, clothing and bedding, food, exercising and sport, medical services, discipline and punishment, instruments of restraint, information to and complaints by prisoners, contact with the outside world, books, religion, retention of prisoners' property, notification of death, illness transfer, removal of prisoners, institutional personnel, inspection and some other rules which are applicable to certain categories of prisoners.

More specifically, principles 27- 32 suggest some rules about discipline and punishment in prison. Based on principle 30(1), disciplinary punishments must be in accordance with the terms and regulations. Principle 31 points to the question of torture directly:

"Corporal punishment, punishment by placing in a dark cell, and all cruel, inhuman or degrading punishments shall be completely prohibited as punishments for disciplinary offences"

Principle 31(3) requires a daily medical examination of prisoners undergoing disciplinary punishments. A medical officer shall advise the director if he considers the termination or alteration of the punishment necessary on grounds of physical or mental health.

There are many other principles so important in prevention of torture and all cruel, inhuman or degrading punishments. For example, principle 8 states that prisoners shall be categorized based on sex, age, criminal record, the legal reason for their detention and the necessities of their treatment. Each category shall be segregated. Therefore, men and

${ }^{116}$ Standard Minimum Rules for the Treatment of Prisoners, GA Res, 663 (XXIV). UN Doc. (1955). 
women should be detained in separate places; untried prisoners should be separated from convicted ones and young prisoners shall be kept separate from adults. Respecting this principle removes many grounds of torturing prisoners by means of other prisoners. For example, keeping a political activist with a dangerous criminal in the same cell can be a torture for the political prisoner, even if the officials have no intention use criminal inmates as torturers. ${ }^{117}$

The subjects of other principles, also, may play an important role in preventing torture from happening. Principle 25 (2) stipulates that:

"The medical officer shall report to the director whenever he considers that a prisoner's physical or mental health has been or will be injuriously affected by continued imprisonment or by any condition of imprisonment."

Medical examination and the obligation to report on the medical status of a prisoner is a safeguard to prevent torture especially considering "Principles of medical ethics relevant to the role of medical personnel, particularly physicians, in the protection of prisoners and detainees against torture and other cruel, inhuman or degrading treatment"118, adopted by the United Nations General Assembly on 18th December 1982. This document is revisited below. $^{119}$

Based on principle 55, there shall be a regular inspection of penal institutions in order to make sure that they are administered in accordance with law. According to the principle

\footnotetext{
${ }^{117}$ For example, Naser Zarafshan, an Iranian human activist, recently sent a message from the prison by his lawyer that he survived a plot to be beaten up by some criminal inmates in his cell. See, "An organized attack to Zarafshan in prison", Gooya News, Saturday, July 31, 2004, available online: http://khabarnameh.gooya.com/politics/archives/014267.php) Zarafshan was charged in connection with disseminating "confidential information" relating to a controversial and widely publicized legal case involving his representation of the children of political activists who were murdered in 1998 as part of what is known in Iran as the "serial murders" case. There have been a lot of concerns about torturing him from the first day of his imprisonment. For more information about him see; Amnesty International report on him: Iran: Imminent flogging/arrest without charge/medical concern, Nasser Zarafshan, lawyer, AI Index: MDE 13/012/2002, 16 August 2002, online (AI website): http://web.amnesty.org/library/index/engMDE130122002?open\&of=eng-irn

${ }^{118}$ Principles of medical ethics relevant to the role of medical personnel, particularly physicians, in the protection of prisoners and detainees against torture and other cruel, inhuman or degrading treatment, UNGA Res. 37/194, 18 Dec. 1982, online UN website:http://www.unhchr.ch/html/menu3/b/h_comp40.htm

${ }^{119}$ See below: sub-section 3.3.6.
} 
36(2), every prisoner has the right to make requests or complaints to the inspector without the director or the other members of the staff being present. This right along with the right to complain to the officials of the prison (principle 36.1) and the right to communicate with their family, reputable friends (principle 37) or the diplomatic and consular representative of their state (principle 38.1) by correspondence or receiving visits can play a tremendous role in providing evidence in case of torture.

Principle 47 suggests that personnel of the prison shall have adequate standards of education and intelligence. Training them before entering the job and supervising them after entering the duty are crucial safeguards against torture.

The Human Rights Committee in its General Comment 21 expressed its view that States should apply the Standard Minimum Rules and that a minimum humanity and dignity must always be guaranteed. Treating all persons deprived of their liberty with humanity and with respect for their dignity is a fundamental and universally applicable rule. ${ }^{120}$

Sub-section 3.3.4: Declaration on the Protection of All Persons from Being Subjected to Torture and Other Cruel, Inhuman or Degrading Treatment or Punishment The UN Declaration on the Protection of All Persons from Being Subjected to Torture and Other Cruel, Inhuman or Degrading Treatment or Punishment ${ }^{121}$ was adopted by the General Assembly on December 9, 1975. The Declaration was a result of magnificent attempts by NGOs, especially Amnesty International, ${ }^{122}$ to report the increasing practice of torture in the world. ${ }^{123}$

${ }^{120}$ ICCPR General Comment No. 21, UN Human Rights Committee, Sess. 44, Apr. 10, 1992, HRI/GEN/1/Rev.1, online (UNHCHR website): http://www.unhchr.ch/tbs/doc.nsf/385c2add 1632f4a8c12565a9004dc311/3327552b951l fb98c12563ed004c be59?OpenDocument

${ }^{121}$ Declaration on the Protection of All Persons from Being Subjected to Torture and Other Cruel, Inhuman or Degrading Treatment or Punishment, G.A. res. 3452 (XXX), annex, 30 U.N. GAOR Supp. (No. 34) at 91, U.N. Doc. A/10034 (1975).

${ }^{122}$ See supra note 91 at 105 , for more information about the role of NGOs, especially Amnesty International, see: Ingelse, Chris, supra note 17 at 67.

${ }^{123}$ Amnesty International frequently releases reports on the practice of torture in the world. In the early 70 s, Amnesty International reported that regimes were using torture justifying that it is necessary in the exceptional circumstances in order to ensure the continued exercise of state authority. This report among other reports concerning practicing torture in different parts of the world encouraged UN to adopt the Declaration on the protection of all persons from being subjected to torture and ... see: Amnesty International, Report on Torture, London: 1973, pp.23-25. Amnesty International continues to be a very 
Although it was not legally binding, it was a successful universal condemnation of torture and formed the first far-reaching guideline for the implementation of existing rules against torture. $^{124}$ Article 1 of the Declaration gives for the first time a definition for torture. It reads:

"1. For the purpose of this Declaration, torture means any act by which severe pain or suffering, whether physical or mental, is intentionally inflicted by or at the instigation of a public official on a person for such purposes as obtaining from him or a third person information or confession, punishing him for an act he has committed or is suspected of having committed, or intimidating him or other persons. It does not include pain or suffering arising only from, inherent in or incidental to, lawful sanctions to the extent consistent with the Standard Minimum Rules for the Treatment of Prisoners.

2. Torture constitutes an aggravated and deliberate form of cruel, inhuman or degrading treatment or punishment."

According to article 2 of the Declaration, all kinds of torture, cruel, inhuman and degrading treatment or punishment are treated as a violation of human rights and essential freedoms.

Article 3 of the Declaration states that:

"No State may permit or tolerate torture or other cruel, inhuman or degrading treatment or punishment. Exceptional circumstances such as a state of war or a threat of war, internal political instability or any other public emergency may not be invoked as a justification of torture or other cruel, inhuman or degrading treatment or punishment."

Article 4 states that states should provide all safeguards to make sure that torture is not in practice in their territories. Article 5 is about the training of police and other public officials, in order to protect detainees from torture. Systematic monitoring of interrogation methods and practices, as well as arrangements for the custody and treatment of persons deprived of their liberty are the subjects of article 6. Article 7 declares that states are obliged to make torture a criminal offence under domestic law.

active on this issue. Amnesty International in one of its recent reports called for reinforcing the fight against torture due to the fact that there are some attempts to legitimize torture in modern times in spite of its absolute prohibition in international Law. See: Amnesty International, No room for complacency: The fight against torture must be reinforced, AI Index: ACT 40/002/2004 (Public), News Service No: 157, 26 June 2004, see online: (A. I. Web Site) http://web.amnesty.org/library/index/engact400022004)

${ }^{124}$ Supra note 89 at 105. 
According to article 8, states should guarantee an effective legal remedy for persons who are subjected to torture or other cruel, inhuman or degrading treatment or punishment. Article 10 states that torturers must be prosecuted and punished, while article 11 insists on compensating victims of torture.

Finally, article 12 challenges the validity of confessions and information extracted using torture or other cruel, inhuman or degrading treatment or punishment. It stipulates that:

"Any statement which is established to have been made as a result of torture or other cruel, inhuman or degrading treatment or punishment may not be invoked as evidence against the person concerned or against any other person in any proceedings"

Sub-section 3.3.5: Code of Conduct for Law Enforcement Officials

This Code of Conduct for Law Enforcement Officials ${ }^{125}$ was adopted on Dec. 17, 1979, in order to support the UN Declaration on the Protection of All Persons from Being Subjected to Torture and Other Cruel, Inhuman or Degrading Treatment or Punishment. $^{126}$ Based on article 1 of this code, law enforcement officials shall fulfill the duty imposed upon them by law, by serving the community and by protecting all persons against illegal acts. To perform such a duty, in accordance with article 2 , they should respect and protect human dignity and human rights as identified by national and international law.

Article 5 of this code reads:

"No law enforcement official may inflict, instigate or tolerate any acts of torture or other cruel, inhuman or degrading treatment or punishment ..."

The code targeted law enforcement officials from two different angles; first, to prevent them from committing the crime of torture, and second, to put them to work as forces who protect detainees from being tortured.

Article 3 allows the use of force by the law enforcement officials when it is necessary and required for the performance of their duty. In accordance with the commentary (a) to the

${ }^{125}$ Code of Conduct for Law Enforcement Officials, UNGA Res. 341/169, 17 Dec. 1979, online UN website: www.unhchr.ch/html/menu $3 / \mathrm{b} / \mathrm{h} \_$comp $42 . h$ tm

${ }^{126}$ Supra note 121. 
article, such authorization to use force is limited to the prevention of crime or in effecting or assisting in the lawful arrest of offenders or suspected offenders.

According to article 6, law enforcement officials shall make sure that full health protection and immediate action to secure medical attention whenever required are available in their custody.

Sub-section 3.3.6: Principles of medical ethics relevant to the role of medical personnel, particularly physicians, in the protection of prisoners and detainees against torture and other cruel, inhuman or degrading treatment

These Principles ${ }^{127}$ were adopted by the United Nations General Assembly on December 18, 1982. Principle 1 admits the right to health care and a healthy environment in prison. ${ }^{128}$ Physicians and other health personnel have a duty to provide prisoners and detainees with protection of their physical and mental health and treatment of the same quality granted to non-prisoners.

Regarding the fact that in some cases torturers use medical information to find more effective methods of torture, ${ }^{129}$ principle 2 states that:

"It is a gross contravention of medical ethics, as well as an offence under applicable international instruments, for health personnel, particularly physicians, to engage, actively or passively, in acts which constitute participation in, complicity in, incitement to or attempts to commit torture or other cruel, inhuman or degrading treatment or punishment"

Sub-section 3.3.7: Convention Against Torture and Other Cruel, Inhuman or Degrading Treatment or Punishment of 10 December 1984

The Convention Against Torture and Other Cruel, Inhuman or Degrading Treatment or Punishment ${ }^{130}$ was adopted on December 10, 1984 by the United Nations General

\footnotetext{
${ }^{127}$ Supra note 118.

${ }^{128}$ For more information about such a right see: Hernan Reyes, Health and human rights in prisons, in "HIV in Prisons: A reader with particular relevance to the newly independent states", ed. World Health Organization-Europe "HIPP" (Health in Prisons Project), 2001, chapter 2, 9-18 at 13.

${ }^{129}$ As an example, I will discuss the role of Pezeshk Ahmadi in Iranian prisons during the Reza Shah reign. He was alleged to be a doctor. Pezeshk means Physician in Persian. See below Section 6.2.

${ }^{130}$ Supra note 32.
} 
Assembly. The Convention came into force on June 27, 1987. As of December 10, 2003, the Convention had been ratified, acceded to or succeeded to by 134 States. The state of Iran is not a signatory to this important Convention. ${ }^{131}$

This convention can be divided into three specific parts:

I. Articles 1 to 16 contain the substantive provisions which state parties must implement in their national laws;

II. Articles 17 to 24 deal with the mandate of the Committee Against Torture, which is the treaty-monitoring body responsible for supervising the implementation of the Convention by state parties. The Committee is discussed in a separate section below ${ }^{132}$;

III. Articles 25 to 33 contain technical matters relating to the signature or ratification of the Convention, procedure for amendments, reservations by state parties and so on.

Article 1 provides a definition of the term "torture" for the purposes of the Convention. This definition is presented and discussed in some detail below. ${ }^{133}$

Because of its far-reaching psychological effects, the harm inflicted by torture on the victim cannot be undone, making prevention of primary importance. Article 2 obliges state parties to take effective measures of prevention with respect to torture. ${ }^{134}$ Such measures include not only clearly outlawing acts of torture and harmonizing their internal legislations with international standards on the prevention of torture, but also training police and security personnel, implementing precise guidelines on the treatment of persons deprived of their liberty, implementing domestic inspection and supervision mechanisms and introducing machinery for the effective investigation of complaints regarding ill-treatment. ${ }^{135}$ Although there are no requirements in international law as to

\footnotetext{
${ }^{131}$ See: Status of the Convention against Torture and Other Cruel, Inhuman or Degrading Treatment or Punishment, Report of the Secretary-General, Commission on Human Rights, Sess. 16 ${ }^{\text {th }}$, E/CN.4/2004/52, 28 Jan. 2004, Para 5, online(UNHCHR web site): http://www.unhchr.ch/Huridocda/Huridoca.nsf/e06a5300f90fa0238025668700518ca4/55be9a1b78651f7ccl 256e5a003401ae/\$FILE/G0410606.doc

${ }^{132}$ See below: part 3.3.7.1.

${ }^{133}$ See below: section 4.1 .

${ }^{134}$ Article 2 reads: “1. Each State Party shall take effective legislative, administrative, judicial or other measures to prevent acts of torture in any territory under its jurisdiction..."

${ }^{135}$ See: Theodor Meron, Human rights in internal strife: Their international protection, (Cambridge: Cambridge university press, 1987) at 28, and Walter Kälin \& Larisa Gabriel, "Human rights in times of
} 
the specific manner in which the prescribed measures must be implemented, it is expected that state parties adopt appropriate preventive measures, attempting to fulfill their obligations under the Convention. ${ }^{136}$

State parties shall also make sure that measures taken by the state are being respected by their officials. ${ }^{137}$ In addition, article 19 provides a kind of informal obligation for state parties to provide measures to prevent torture. In accordance with this article of the Convention, state parties shall submit reports on the measures they have taken within one year after the entry into force of the Convention for the state party concerned. Also, state parties shall submit supplementary reports every four years on any new measures taken, as well as other reports upon request of the Committee.

Article 2(2) stipulates that torture cannot be justified under any circumstances including war, public emergency or internal political instability. The list of exceptional circumstances referred to the paragraph is not exhaustive. The word "whatsoever" was used in this article by drafters in order to close the door to an interpretation that those exceptional circumstances are exhaustive. ${ }^{138}$ Thus, the prohibition of torture is absolute in that there is no justification for torture, and the right of protection against torture is a nonderogable right. ${ }^{139}$ Even an order from a superior officer or a public authority may not be invoked as justification of torture (Article 2(3)). The question of order from superiors had already mentioned in international law. For example, based on article 8 of the Charter of

occupation: An introduction", in Human rights in times of occupation: The case of Kuwait, ed. Walter Kälin, (Bern, 1994) at 26-29.

${ }^{136}$ See: Mohammad Ali Ardebili, Torture: an article in the occasion of $150^{\text {th }}$ anniversary of banning torture in Iran, Tehran Justice Administration Collection, No. 9, July 1991 at 5. Available online (Tehran Justice Administration Web Site): http://www.ghavanin.com/PaperDetail.asp?id=215.

137 Ibid

${ }^{138}$ Ahcene Boulesbaa, The UN Convention on Torture and the Prospects for Enforcement, (Martinus Nijhoff Publishers, 1999)at 79.

${ }^{139}$ Such an absoluteness is emphasized by Committee against Torture in several occasions: "...no exceptional circumstances can ever provide a justification for failure to comply with the terms of the Convention"; see: Summary record of the first part of the 354th meeting : Yugoslavia, United Kingdom of Great Britain and Northern Ireland, Committee against Torture, UN Doc. CAT/C/SR.354, 18 November 1998, Sess. 21, Geneva, at C 8. Online (UNCHR website): http://www.unhchr.ch/tbs/doc.nsf/385c2add1632f4a8c12565a9004dc311/7473cd55688cd6bed802566c6003d 7f4e?OpenDocument\&Highlight $=0$, CAT\%2FC\%2FSR.354 
the International Tribunal of Nuremberg, ${ }^{140}$ to act under order was not justification for serious international crimes including torture. It must be kept in mind that in accordance with general principles of international law, the fact that someone was under order to commit a crime may be considered in sentencing but not in prosecuting. ${ }^{141}$

Article 3 prohibits the expulsion of individuals to a state where there are substantial grounds for believing that they would be in danger of being subjected to torture. If there is a risk of torture in a given state, the sending state shall refrain from transferring persons to such a state. ${ }^{142}$ This article overrides any conflicting provisions of an extradition agreement that may have been signed between the state parties. If a state party enters a treaty which contains provisions conflicting with article 3 , it would be in breach of the Convention. ${ }^{143}$

The burden of proof in a torture case is on the potential victim. However, the state party shall consider the situation of human rights, the person's background and other grounds for believing the possibility of such a danger. The Committee Against Torture in its consideration of communication No. 28/1995, submitted to the Committee Against Torture by a Turkish citizen of Kurdish ethnic origin whose request for political asylum has been refused in Switzerland, considered the human rights situation in Turkey where torture is systematically practiced, the situation of Kurds in general, and members of

\footnotetext{
${ }^{140}$ Charter of the International Military Tribunal, Signed in quadruplicate in Berlin, $6^{\text {th }}$ October 1945. Article 8 reads: "The fact that the Defendant acted pursuant to order of his Government or of a superior shall not free him from responsibility, but may be considered in mitigation of punishment if the Tribunal determines that justice so requires." online: http://www.yale.edu/lawweb/avalon/imt/proc/imtconst.htm\#art8

${ }^{141}$ See: Article 6 of the Charter of the International Military Tribunal for the Far East, 1946, available on line: http://www.yale.edu/lawweb/avalon/imtfech.htm; also see: article 6 of the Statute of The International Criminal Tribunal for Rwanda, UN Res.1165 (April 30, 1998) avaialble online: http://www.un.org/ictr/statute.html and article 7 of the Statute of the International criminal Tribunal for the Former Yugoslavia, Security Council Res. 827, 25 May 1993, available online: http://www.un.org/icty/basic/statut/stat11-2004.htm

${ }^{142}$ Article 3: "1. No State Party shall expel, return ("refouler") or extradite a person to another State where there are substantial grounds for believing that he would be in danger of being subjected to torture.

2. For the purpose of determining whether there are such grounds, the competent authorities shall take into account all relevant considerations including, where applicable, the existence in the State concerned of a consistent pattern of gross, flagrant or mass violations of human rights."

${ }^{143}$ See: Reza Norbaha, Torture as it is defined in the Convention against Torture, Tehran Justice Administration Collection, No. 149, Dec. 1989 at 4, online (Tehran Justice Administration Web Site): http://www.ghavanin.com/PaperDetail.asp?id=180
} 
illegal Kurdish political parties in particular. Additionally, they considered the potential victim's family background, noting that some members of his family are politically active and being persecuted by the authorities. Finally, the Committee came to the conclusion that he would be in danger of being detained and tortured if he were to return to his country. $^{144}$

In November 1996, the Committee Against Torture in its $19^{\text {th }}$ session, in its General Comment on "Implementation of article 3 of the Convention in the context of article $22, " 145$ provided a full guideline for states and individuals. According to article 4, all state parties shall ensure that torture, the attempt to commit torture, and complicity in torture are punishable offences with appropriate penalties under their domestic law. ${ }^{146}$ The Convention Against Torture recommends that state parties define torture in conformity with the definition given in article 1 of the Convention in some of its considerations of initial and periodic reports from states parties. ${ }^{147}$

To implement paragraph 2 of article 4, state parties should make torture punishable in their domestic laws. Such a punishment must be proportionate considering the grave nature of the offence. Therefore the penalties must be severe and comparable to the

\footnotetext{
${ }^{144}$ Views of the Committee Against Torture under article 22 of the Convention against Torture and Other Cruel, Inhuman or Degrading Treatment or Punishment, Committee Against Torture, Sess. $19^{\text {th }}$, Communication No. 28/1995: Switzerland, CAT/C/19/D/28/1995, 10 November 1997. Online (UNCHR website): http://www.unhchr.ch/tbs/doc.nsf/(Symbol)/CAT.C.19.D.28.1995.En?Opendocument

${ }^{145}$ Implementation of article 3 of the Convention in the context of article 22, General Comment no. 1, Committee against Torture, UN Doc. A $/ 53 / 44$, annex IX, Sess. $19^{\text {th }}$, meeting $317^{\text {th }}$, Nov. 21,1997 . Online (UNCHR website): http://www.unhchr.ch/tbs/doc.nsf/0/13719f169a8a4ff78025672b0050eba1?Opendocument

${ }^{146}$ Article 4: "1. Each State Party shall ensure that all acts of torture are offences under its criminal law. The same shall apply to an attempt to commit torture and to an act by any person which constitutes complicity or participation in torture. 2. Each State Party shall make these offences punishable by appropriate penalties which take into account their grave nature."

${ }^{147}$ For example, Committee against Torture mentioned the fact that Armenian Penal Law has not created a specifically defined crime of torture as a matter of concern. It is also recommend Armenia to define torture definition of torture in conformity with the definition appearing in article 1 of the Convention. For more information see: Summary record of the public part of the 246th meeting: Armenia, Committee against Torture, Sess. $16^{\text {th }}$, UN Doc. CAT/C/SR.246, Geneva, 3 May 1996, Para. D\&E, Online (UNHCHR website):

http://www.unhchr.ch/tbs/doc.nsf/385c2add1632f4a8c12565a9004dc311/76f8e66a61689a28c125642d003e 6108? OpenDocument\&Highlight=0,Armenia also see: Summary record of the public part of the 279 th meeting : Georgia, Poland, Committee against Torture, Sess. 1 $7^{\text {th }}$, Geneva, Doc. CAT/C/SR.279, 21 March 1997, Online (UNHCHR website):

http://www.unhchr.ch/tbs/doc.nsf/385c2add1632f4a8c12565a9004dc311/90f1015e2ed1e3d28025646c004d 6a34?OpenDocument\&Highlight $=0$, CAT\%2FC\%2FSR.279
} 
penalties imposed by the national law for similar crimes. ${ }^{148}$

As one of the most important articles of the Convention, article 5 obliges state parties to establish universal jurisdiction over the crime of torture, where the alleged offenders are not extradited to face prosecution in another state. ${ }^{149}$ Article 5 provides a system of enforcement under which there is no safe haven for the torturers by facilitating the assertion of jurisdiction by states over torture. A state party can arrest a non-national alleged offender who is present in its territory on the basis of universal jurisdiction. ${ }^{150}$ Bearing in mind that states may be involved in committing the crime of torture and may refrain from punishing their own agents, many of torturers may benefit from a kind of impunity in their own countries while another state can react to their crimes on the basis of its universal jurisdiction over the crime of torture if they are found in its territory. ${ }^{151}$ According to the Committee Against Torture, ${ }^{152}$ the states' obligation to bring alleged torturers to justice can be extended to any official, no matter how high his position. The case of Augusto Pinochet, former president of Chile, is a good example of application of such an opinion. ${ }^{153}$

Articles 6 to 8 contain regulations on the exercise of universal jurisdiction as established in article 5. The duty to take suspected persons into custody, to commission inquiries into allegations of torture, and to submit suspected torturers to the prosecuting authorities are among the important stipulations in these articles.

\footnotetext{
${ }^{148}$ See: Ingelse, supra note 17 at 340; also see: Mohammad Ali Ardebili, supra note 136 at 4.

${ }^{149}$ Article 5: "1. Each State Party shall take such measures as may be necessary to establish its jurisdiction over the offences referred to in article 4 in the following cases: (a) When the offences are committed in any territory under its jurisdiction or on board a ship or aircraft registered in that State; (b) When the alleged offender is a national of that State; (c) When the victim is a national of that State if that State considers it appropriate. 2. Each State Party shall likewise take such measures as may be necessary to establish its jurisdiction over such offences in cases where the alleged offender is present in any territory under its jurisdiction and it does not extradite him pursuant to article 8 to any of the States mentioned in paragraph I of this article. 3. This Convention does not exclude any criminal jurisdiction exercised in accordance with internal law."

${ }^{150}$ J. Herman Burgers \& Hans Danelius, The United Nations Convention against Torture: A Handbook on the Convention against Torture and other Cruel, Inhuman or Degrading Treatment or Punishment, (Martinus Nijhoff Publishers, 1988), at 120.

${ }^{151}$ See: Ingelse, Chris, supra note 17 at 83.

${ }^{152}$ See: Summary record of the first part of the 354th meeting : Yugoslavia, United Kingdom of Great Britain and Northern Ireland, supra note 139 at C14 \& D17.

${ }^{153}$ Infra note 196.
} 
Article 9 provides that state parties assist one another in criminal proceedings concerning torture, while article 10 obliges state parties to disseminate information on the prohibition against torture, and to train law enforcement officials and others in this subject. States parties are obliged to ensure that education and information regarding the prohibition of torture are fully included in training of all persons who come into contact with detainees, including police officers, medical personnel, public officials and other persons who may be involved in the custody, interrogation, or treatment of any individuals subjected to any form of arrest, detention or imprisonment. ${ }^{154}$

Article 11 stresses that state parties must continually review their interrogation rules and arrangements for custody with a view to preventing torture. Many UN instruments provide guidelines on how to prohibit and prevent torture. ${ }^{155}$ Article 12 provides for prompt and impartial investigation where there are reasonable grounds to believe that torture has been committed. Allegations from NGOs may constitute such reasonable grounds. ${ }^{156}$ The impartiality of investigation shall be provided by avoiding entrusting the investigation to persons who have close personal or professional links with those suspected of having committed torture or who may have interest in protecting those suspects. $^{157}$

Articles 13 and 14 provide victims and their dependents the right to redress, protection and compensation, while article 15 prohibits the use of evidence obtained through torture. It reads:

\footnotetext{
${ }^{154}$ Reza Norbaha, supra note 143 at 5; also see: Concluding Observations : Egypt, Committee against Torture, Sess. 29, $11-22$ Nov. 2002, CAT/C/XXIX/Misc.4 at 6(q), online (UNHCHR website): http://www.unhchr.ch/tbs/doc.nsf/385c2add1632f4a8c12565a9004dc311/b890e8850e3b29dec1256c780031 f838? OpenDocument

155 e. g.: The Standard Minimum Rules for the Treatment of Prisoners $(1957,1977)$, Basic Principles for the Treatment of Prisoners (1990), the Body of Principles for the Protection of All Persons Under Any Form of Detention or Imprisonment (1988), United Nations Rules for the Protection of Juveniles Deprived of Their Liberty (1990), Principles of Medical Ethics relevant to the Role of Health Personnel, particularly Physicians, in the Protection of Prisoners and Detainees against Torture and Other Cruel, Inhuman or Degrading Treatment or Punishment (1982), Code of Conduct for Law Enforcement Officials (1979), Use of Force and Firearms by Law Enforcement Officials (1990), Basic Principles on the Role of Lawyers (1990), United Nations Standard Minimum Rules for Non-Custodial Measures (The Tokyo Rules 1990), United Nations Standard Minimum Rules for the Administration of Juvenile Justice (The Beijing Rules).

${ }^{156}$ Concluding Observation: Cameroon, Committee against Torture, Sess. 45, CAT A/45/44, 1990, Para 265, online: http://66.36.242.93/pdf/cameroon t4 cat.pdf

${ }^{157}$ Supra note 150 at 145.
} 
"Each State Party shall ensure that any statement which is established to have been made as a result of torture shall not be invoked as evidence in any proceedings, except against a person accused of torture as evidence that the statement was made."

Article 15 applies only to statements made under torture and not to statements made under cruel, inhuman, or degrading treatment. However, the Committee Against Torture emphasizes that the article is applicable to cruel, inhuman, or degrading treatment or punishment as well. ${ }^{158}$ The UN Human Rights Committee has the same suggestion with regard to article 7 of the ICCPR. ${ }^{159}$

According to article 16 of the Convention, state parties not only obliged to take measures to prevent torture, but also to prevent cruel, inhuman, or degrading treatment or punishment which does not amount to torture as defined in article1.

\section{Part 3.3.7.1: Committee Against Torture}

The Committee Against Torture (CAT) is one of the UN treaty bodies created by article 17 of the Convention Against Torture to supervise the implementation of states' obligations under the Convention. ${ }^{160}$ It created a new challenge between recognition of state sovereignty and preventing states from the violation of human rights by means of international legislation. ${ }^{161}$

The Committee consists of ten experts of high moral standing and with recognized competence in the field of human rights. They are elected for a period of 4 years by the state parties from among nominees proposed by the state parties. As it is clear in article 18 , members of the Committee do not represent their national states or any other state or organization. Rather, they serve in their personal capacities.

\footnotetext{
${ }^{158}$ For example see: Summary record of the 419th meeting : China, Poland, Committee against Torture, $24^{\text {th }}$ sess., CAT/C/SR.419, 12 May 2000, Geneva, online (UNHCHR website):

http://www.unhchr.ch/tbs/doc.nsf/385c2add1632f4a8c12565a9004dc311/97b22a78ff7adfe2802568e300351 8ae?OpenDocument

${ }^{159}$ ICCPR General Comment no.20, supra note 105, para 12.

${ }^{160}$ Article 17: "1. There shall be established a Committee against Torture (hereinafter referred to as the Committee) which shall carry out the functions hereinafter provided. The Committee shall consist of ten experts of high moral standing and recognized competence in the field of human rights, who shall serve in their personal capacity. The experts shall be elected by the States Parties, consideration being given to equitable geographical distribution and to the usefulness of the participation of some persons having legal experience 2...."

${ }^{161}$ Ingelse, Chris, supra note 17 at 84.
} 
The Committee is responsible for monitoring the extent to which state parties respect their obligations to prevent, prohibit, and punish torture under the Convention. Based on article 19 , every state party shall within one year of singing submit an initial report on the measures they have taken to give effect to the provisions of the Convention. In addition, the state parties shall submit supplementary reports every four years on any new measures taken and such other reports as the Committee may request. The Committee will examine the reports in order to identify any areas of concern. The committee draws conclusions and makes recommendations to the state parties. The Convention Against Torture allows the Committee to investigate situations of systematic violations and, with the consent of the state party concerned, to carry out on-site visits. ${ }^{162}$

In addition to the examination of the state parties' reports, the Committee may set a confidential inquiry into allegations of a systemic practice of torture based on article 20 of the Convention. According to Article 28, a State Party may, at the time of signature or ratification of the Convention, declare that it does not recognize the competence of the Committee to carry out investigations under Article 20. As of December 10, 2003, seven States had declared, in accordance with article 28 , that they do not recognize the competence of the Committee provided for in article 20 of the Convention. ${ }^{163}$

Article 21 provides the possibility of a kind of inter-state supervision of state parties. A state party to the Convention may declare at any time that it recognizes the competence of the Committee Against Torture to receive and consider communications to the effect that a State party claims that another State party is not fulfilling its obligations under the Convention.

Article 22 of the Convention provides a unique possibility for individuals to claim to be a victim of torture. According to this article, a state can accept the competence of the Committee to receive and consider communications from, or on behalf of, individuals subject to its jurisdiction who claim to be victims of a violation of the convention. ${ }^{164}$

\footnotetext{
${ }^{162}$ Article 20 of the Convention against Torture, supra note 32.

${ }^{163}$ See: Status of the Convention against Torture and Other Cruel, Inhuman or Degrading Treatment or Punishment, supra note 131, para 8.

${ }^{164}$ For example see: Communication No. 236/2003: Switzerland, Committee Against Torture, Sess. $31^{\text {th }}$, CAT/C/31/D/236/2003, 14 November 2003. Online (UNCHR website):
} 
As of December 2003, 50 of the states party to the Convention had made the declarations provided for in articles 21 and 22 of the Convention. ${ }^{165}$ The Committee provides an annual report to the General Assembly including a summary of the complaints, a list of the observations and comments of the states in question, and the Committee's decisions. $^{166}$

Part 3.3.7.2: Optional Protocol to the Convention Against Torture and Other Cruel, Inhuman or Degrading Treatment or Punishment

In the General Assembly Resolution 57/199 of December 18, 2002 the Optional Protocol to the Convention ${ }^{167}$ was adopted as a new mechanism aimed at preventing torture. The Protocol was opened for signature on February 4, 2003. As of December 10, 2003, 22 States had signed the Optional Protocol. ${ }^{168}$

The Optional Protocol provides very practical means to help prevent torture and illtreatment within places of detention. It establishes a new international body, a subcommittee, solely concerned with preventing these forms of abuse through a system of inspection visits to places of detention. The aim of the visits is to assess the condition of detention and the treatment of those detained, and to make recommendations to state parties for improvements. The Protocol also requires state parties to set up national mechanisms to conduct visits to places of detention and to cooperate with international experts. These visits are to be followed by concrete recommendations given to the authorities concerned as to how they can prevent torture and ill-treatment.

The Optional Protocol also supports the national implementation of the obligation to prevent torture, by requiring all state parties to have in place independent national bodies to conduct

http://www.unhchr.ch/tbs/doc.nsf/385c2add1632f4a8c12565a9004dc311/3dd183ecdfe4ddeec1256df600584 756? OpenDocument

${ }^{165}$ See: supra note 163 , para 6.

${ }^{166}$ e.g.: Report of the Committee against Torture to $57^{\text {th }}$ session of the UN General Assembly, CAT A/57/44, 01/11/2002, Available online(UNHCHR web site): http://www.unhchr.ch/tbs/doc.nsf/385c2add1632f4a8c12565a9004dc311/4efa83432a585f76c1256c690036a 985/\$FILE/N0264707.pdf

167 Optional Protocol to the Convention Against Torture and Other Cruel, Inhuman or Degrading Treatment or Punishment, G.A. res. A/RES/57/199, adopted Dec. 18, 2002 [reprinted in 42 I.L.M. 26 (2003) available online (OHCHR website): http://www.ohchr.org/english/law/cat-one.htm

${ }^{168}$ See: supra note 163 , Para 8. 
regular visits to places of detention. These are to complement the less frequent visits undertaken by the international Subcommittee. Two international NGO's, Amnesty International ${ }^{169}$ and the Association for the Prevention of Torture (APT), ${ }^{170}$ did a tremendous job of convincing the UN to adopt this Protocol. States shall ratify this document as soon as possible in order to provide a more effective body to prevent torture.

Sub-section 3.3.8: Body of principles for the protection of all persons under any form of detention or imprisonment

On December 9, 1988, the General Assembly of the UN adopted a resolution entitled "Body of principles for the protection of all persons under any form of detention or imprisonment"171. According to principle 1 of this document, "all persons under any form of detention or imprisonment shall be treated in a human manner and with respect for the inherent dignity of the human person". Principle 6 bans the use of torture in prisons and custodies:

\section{"No person under any form of detention or imprisonment shall be subjected to torture or to cruel, inhuman or degrading treatment or punishment. No circumstance whatever may be invoked as a justification for torture or other cruel, inhuman or degrading treatment or punishment."}

Moreover, it states that no circumstances may be invoked to justify torture. Other points, which are of the utmost importance in providing safeguards against the use of torture, are illustrated as follows:

1. All arrests, detention and imprisonment shall be in accordance with law and carried out by officials (Principle 2).

2. Arresting and detaining must be supervised and controlled by a judicial or other authority (Principle 4).

\footnotetext{
${ }^{169}$ See: Amnety International, Preventing Torture Worldwide - The Optional Protocol to the Convention against Torture, AI Index: IOR 51/002/2003, 1 June 2003, online (AI website): http://web.amnesty.org/library/Index/ENGIOR510022003?open\&of=ENG-393

${ }^{170}$ For APT attempts see: Optional Protocol to the Convention against Torture, APT Journal, No. 1, Dec. March 1996, 4-6.

${ }^{171}$ Body of principles for the protection of all persons under any form of detention or imprisonment, UNGA Res. 43/173, Dec. 9, 1988. Available online (UNHCHR website): http://www.unhchr.ch/htm1/menu3/b/h_comp $36 . \mathrm{htm}$
} 
3. Persons in detention shall be kept separate from convicted prisoners (Principle 8).

4. All information related to the arrest such as the reason of arrest, the time and place of arrest, the identity of law enforcement officials and location of custody should be recorded (Principle 12).

5. The detainee or his council must be informed about the reason of the arrest, location of the custody and the identity of the official who arrested him (Principle 12).

6. The detainee's communication with the outside world should not be denied except in special cases mentioned in principle 16 (Principle 15).

7. Any detainee holds the right to legal assistance and must be granted the possibility to communicate with his lawyer (Principles 17 \&18).

8. Every detainee is entitled to be visited by his family (Principle 19).

9. No detainee shall be subjected to violence during the interrogation (Principle 21.)

10. All negotiations during the interrogation shall be recorded (Principle 23).

11. A proper medical examination must be offered to a detainee or prisoner (Principle 24).

12. Security and good order in the place of the detention must be provided for the detainee, prisoner, or his lawyer (Principle 25).

13. The name of the physician and the result of any medical examination must be recorded, and access to such information must be insured (Principle 26).

14. Qualified and experienced persons must supervise places of detention or imprisonment regularly; in addition, prisoners and detainees should have the opportunity of communicating with such a supervisor freely (Principle 29).

15. Disciplinary offences during detention or imprisonment could be a good excuse to impose pressure on the detainee or prisoner by torturers. The law shall specify the description, the duration of these punishments and the competent authorities to impose them. Detainees or prisoners who are subjected to such disciplinary punishments shall be heard before such punishments are carried out (Principle 30).

16. A detainee or his lawyer has the right to take proceedings before a judicial or other authority to challenge the lawfulness of his detention (Principle 32).

17. If the detainee is subjected to maltreatment, especially in the case of torture, he or his 
lawyer or members of his family, or even any other person who has knowledge of the case, can exercise the detainee's right to make a request to hold an inquiry or to file a complaint about the situation (Principle 33).

18. If one of the detainees or prisoners dies or disappears in custody or prison, or shortly after being released, judicial or other the authority should hold an inquiry with or without request of a member of the family of the person who died or disappeared (Principle 34).

19. Damages out of violation of these principles must be compensated (Principle 35).

20. Keeping a person in custody must be upon a written order by an authority. A detainee is entitled to make a statement on the treatment received while in custody (Principle 37).

All these matters, if provided together and when enforced, could be sufficient safeguards to protect detainees from being tortured. It seems that reformist lawmakers in Iran bore these principles in mind while providing the "Bill to protect the Rights of Accused or Convicted People". ${ }^{172}$

\section{Sub-section 3.3.9: Convention on the Rights of the Child}

The Convention on the Rights of the Child (1989), ${ }^{173}$ to which $\operatorname{Iran}^{174}$ is a party since 1993, stipulates in article 37 that, "No child shall be subjected to torture ..." In addition, article 40 states that a child shall not be compelled to give testimony or to confess guilt. This Convention has been signed by more countries than any other human rights treaty. Unfortunately, there is no provision for individuals to make a complaint if the rights it addresses are violated.

\footnotetext{
${ }^{172}$ See below: sub-section 8.1.3.

${ }^{173}$ The convention on the rights of the child, UNGA Res. 44/25, Nov. 20, 1989, online; UN website: www.unhchr.ch $/ \mathrm{html} / \mathrm{menu} 3 / \mathrm{b} / \mathrm{k} 2 \mathrm{crc}$.htm; to see the status of the treaty check this address: http://www.unhchr.ch/pdf/report.pdf

${ }^{174}$ Islamic Republic of Iran made two reservations; first, reservation upon signature: "The Islamic Republic of Iran is making reservation to the articles and provisions which may be contrary to the Islamic Shariah, and preserves the right to make such particular declaration", second, reservation upon its ratification: "The Government of the Islamic Republic of Iran reserves the right not to apply any provisions or articles of the Convention that are incompatible with Islamic Laws and the international legislation in effect." To see other reservations on CRC check this address online: http://www.unhchr.ch/html/menu3/b/treaty 15 asp.htm
} 
Sub-section 3.3.10: Basic Principles for the Treatment of Prisoners,

The Basic Principles for the Treatment of Prisoners ${ }^{175}$ were adopted and proclaimed by General Assembly Resolution 45/111 of December 14, 1990. Article 1 stipulates that "All prisoners shall be treated with the respect due to their inherent dignity and value as human beings". Article 5 emphasizes the human rights of the prisoners set out in the Universal Declaration of Human Rights, and, where the State concerned is a party, the International Covenant on Economic, Social and Cultural Rights, and the International Covenant on Civil and Political Rights and other rights as are set out in other United Nations covenants. Additionally, the question of solitary confinement as punishment is addressed in article 7 . States are encouraged to abolish such punishment, or at minimum restrict its use in their prisons.

\section{Sub-section 3.3.11: Basic Principles on the Role of Lawyers}

Basic Principles on the Role of Lawyers ${ }^{176}$ were adopted by the $8^{\text {th }}$ United Nations Congress on the Prevention of Crime and the Treatment of Offenders in 1990. The Preamble and Articles 2, $3 \& 6$ of these Basic Principles require states, as a central part of their responsibility to protect human rights, to ensure equal access to lawyers and specifically to provide sufficient funding for legal services to the poor. Having access to the lawyers is a very effective safeguard to prevent torture.

Since its inception in 1945, the United Nations has sought to uphold a universal understanding of, and respect for, human rights. The prevention of torture is intimately tied to the notion of human rights and respect for human dignity. This survey of various UN instruments aimed at eliminating all types of torture illustrates the preoccupation international law has had with preventing torture world-wide.

\footnotetext{
${ }^{175}$ Basic Principles for the Treatment of Prisoners, GA res. 45/111, 14 December 1990, online(UNHCHR web site) : http://www.unhchr.ch/html/menu3/b/h comp35.htm

${ }^{176}$ Basic Principles on the Role of Lawyers, adopted by the $8^{\text {th }}$ United Nations Congress on the Prevention of Crime and the Treatment of Offenders, Havana 27 August to 7 September 1990. U.N. Doc. A/CONF. 144/28/Rev. 1, online(UNHCHR website): http://www.unhchr.ch/html/menu3/b/h_comp44.htm
} 


\section{Section 3.4: Regional efforts against torture}

This section reviews some of the most important regional efforts to eradicate torture and other cruel, inhuman or degrading treatments.

\section{Sub-section 3.4.1: European Convention on Human Rights}

The European Convention on Human Rights and Fundamental Freedoms (ECHR) ${ }^{177}$, entered into force on November 4, 1953, and repeated article 5 of the UDHR using almost the same text. Article 3 reads: "No one shall be subjected to torture or to inhuman or degrading treatment or punishment." According to Article 15 of the ECHR, the right stipulated in article 3 was described as "notstandsfest", meaning that member states cannot by law limit or violate the ban on torture; not even a state of emergency can violate this ban. ${ }^{178}$

Provisions in article 5 guarantee the right to liberty and security of person. Although, these provisions are not directly related to the question of torture, some of them can play a role in preventing torture. Arresting and detaining an individual shall be in accordance with the lawful order of a court. The detainee has the right to be tried within a reasonable time by a competent court. The detainee shall be entitled to take proceedings to challenge the lawfulness of his detention.

The treaty, in article 19, established the European Court of Human Rights. Based on article 33, any state party may refer to the court any alleged breach of the Convention by another state party. Moreover, any person, non-governmental organization or group of individuals can claim to be the victim of a violation of the rights set forth in the Convention by one of the state Parties in accordance with article 34 . There have been many cases on torture heard in the European Court of Human Rights that provided a

\footnotetext{
${ }^{177}$ The European Convention on Human Rights and Fundamental Freedoms, Council of Europe, European Treaties, ETS No.5, Rome Nov. 4, 1950, entered into force Nov. 4, 1953. Online: http://www.hri.org/docs/ECHR50.html.

${ }^{178}$ Article 15 of the ECHR states: "In time of war or other public emergency threatening the life of the nation any High Contracting Party may take measures derogating from its obligations under this Convention to the extent strictly required by the exigencies of the situation, provided that such measures are not inconsistent with its other obligations under international law. 1- No derogation from Article 2, except in respect of deaths resulting from lawful acts of war, or from Articles 3, 4 (paragraph 1) and 7 shall be made under this provision."
} 
rich case law in both European law and customary international law. ${ }^{179}$

Sub-section 3.4.2: European Convention for the prevention of torture and inhuman or degrading treatment or punishment

The European Convention for the prevention of torture and inhuman or degrading treatment or punishment ${ }^{180}$ was adopted in 1987. Article 1 of the Convention established the European Committee for the Prevention of Torture and Inhuman or Degrading Treatment or Punishment (CPT). The committee's mandate as a non-judicial body is to visit and examine the treatment of detainees and prisoners in order to protect them from torture and other Inhuman or Degrading Treatment or Punishment.

The Committee's members are independent and impartial experts from a variety of backgrounds. They include lawyers, medical doctors and specialists in prison or police matters. They are elected for a four-year term by the Committee of Ministers, the Council of Europe's decision-making body, and can be re-elected twice. One member is elected in respect of each Contracting State but they serve in their individual capacity and not representing their national states (article 4). ${ }^{181}$ According to article 8 of the Convention, CPT delegations have unlimited access to places of detention and the right to move inside such places without restriction. They interview persons deprived of their liberty in private and communicate freely with anyone who can provide information.

The recommendations which the CPT may formulate on the basis of facts found during the visit are included in a report which is sent to the State concerned. This report is the starting point for an ongoing dialogue with the State concerned (article 10).

\footnotetext{
${ }^{179}$ For example, some cases have suggested criteria to distinguish between torture, inhuman and degrading treatment, degrading punishment and degrading treatment. Some of these cases are discussed below: section 4.1.

${ }^{180}$ The European Convention for the prevention of torture and inhuman or degrading treatment or punishment, supra note 69.

${ }^{181}$ For more information see: Antonio Cassese, "The European Committee for the Prevention of Torture and Inhuman or Degrading Treatment or Punishment" in The international fight against torture, ed. Antonio Cassese ( Baden-Baden, 1991) 135-152.
} 
Sub-section 3.4.3: American Convention on Human Rights

In 1969, the American Continent took a similar step to that of Europe. American states ratified the American Convention on Human Rights $(\mathrm{ACHR})^{182}$, which came into force on July 18,1978 . This convention in article 5 stipulates:

"1-Every person has the right to have his physical, mental and moral integrity respected.

2- No one shall be subjected to torture or to cruel, inhuman or degrading punishment or treatment. All persons deprived of their liberty shall be treated with respect for the inherent dignity of the human person."

In accordance with article 27 of the convention, the ban on torture and cruel, inhuman or degrading treatment or punishment is "notstandsfest".

In accordance with article 34 of the American Convention on Human Rights, the InterAmerican Commission on Human Rights is composed of 7 members. The main function of the Commission, based on article 41 , is to promote respect for and defense of human rights. This Commission has the right of access to places of detention and of talking to detainees without witnesses (article 19).

\section{Sub-section 3.4.4: African Charter on Human and Peoples' Rights}

Another important regional convention is the 1981 African Charter on Human and Peoples' Rights (ACHRPR) ${ }^{183}$. Article 5 of this convention, which came into force on October 21, 1986, states:

"Every individual shall have the right to the respect of the dignity
inherent in a human being and to the recognition of his legal status. All
forms of exploitation and degradation of man particularly slavery,
slave trade, torture, cruel, inhuman or degrading punishment and
treatment shall be prohibited." Based on articles 30 and 31, an African Commission on Human and Peoples' Rights consisting of 11 members chosen among African personalities has been established

\footnotetext{
${ }^{182}$ American Convention on Human Rights, O.A.S.Treaty Series No. 36, 1144 U.N.T.S. 123 entered into force July 18, 1978, reprinted in Basic Documents Pertaining to Human Rights in the Inter-American System, OEA/Ser.L.V/II.82 doc.6 rev.1 at 25 (1992).

${ }^{183}$ African Charter on Human and Peoples' Rights, adopted June 27, 1981, OAU Doc. CAB/LEG/67/3 rev. 5, 21 I.L.M. 58 (1982), entered into force Oct. 21, 1986.
} 
within the Organization of African Unity to promote human and peoples' rights and ensure their protection in Africa. Members of the Commission serve in their personal capacity.

The convention did not provide a legally binding authority of the African Commission, or the Assembly of Heads of States, in order to guarantee and protect the rights in case of violation. $^{184}$

\section{Section 3.5: Other international efforts}

Today, torture is a crime against humanity in international law. ${ }^{185}$ According to UN Security Council Resolution no.764 (1992) ${ }^{186}$, individuals who commit or order to commit grave breaches are to be held responsible. This responsibility has been taken more seriously about breaches occurring in the territory of former Yugoslavia in the Statute of the International Tribunal for the Prosecution of Persons Responsible for Serious Violations of International Humanitarian Law Committed in the Territory of the Former Yugoslavia since 1991. ${ }^{187}$

Torture or inhuman treatments including biological experiments have been counted among other crimes in article 2 of the Statute ${ }^{188}$. The international tribunal has the power to prosecute individuals who commit torture or are ordered to commit torture. ${ }^{189}$

Article 3 of the Statute of the International Tribunal for Rwanda ${ }^{190}$ has counted torture as a crime against humanity, capable of being considered among other crimes, and

\footnotetext{
${ }^{184}$ For more information see: Ingelse, Chris, supra note 17 at 51.

${ }^{185}$ Henry J. Steiner \& Philip Alston, supra note 86 at 1144.

${ }^{186}$ UN Security Council 3093rd Meeting Resolution S/RES/764 July 13, 1992. http://ods-ddsny.un.org/doc/RESOLUTION/GEN/NR0/011/23/IMG/NR001123.pdf?OpenElement

${ }^{187}$ Statute of the International Tribunal for the Prosecution of Persons Responsible for Serious Violations of International Humanitarian Law Committed in the Territory of the Former Yugoslavia since 1991, Security Council Resolution 808, U.N. Doc. S/25704 (Feb. 22, 1993). http://ods-ddsny.un.org/doc/UNDOC/GEN/N93/098/21/IMG/N9309821.pdf?OpenElement ${ }^{188}$ Ibid.

${ }^{189}$ For more information see: Henry J. Steiner \& Philip Alston, supra note 86 at 1150.

${ }^{190}$ The International Criminal Tribunal for the Prosecution of Persons Responsible for Genocide and Other Serious Violations of International Humanitarian Law Committed in the Territory of Rwanda and Rwandan citizens responsible for genocide and other such violations committed in the territory of neighboring States, between I January 1994 and 31 December 1994, annexed to U. N. Security Council Resolution 955, S.C. res. 955, U.N. Doc. S/RES/955 (1994), online: http://ods-ddsny.un.org/doc/UNDOC/GEN/N95/140/97/PDF/N9514097.pdf?OpenElement
} 
demanding prosecution for any individuals who commit or order to commit them. ${ }^{191}$ The Rome Statute of the International Criminal Court ${ }^{192}$, in article 7 , has pointed to torture among other crimes as “crime against humanity". It reads:

"For the purpose of this Statute, "crime against humanity" means any of the following acts when committed as part of a widespread or systematic attack directed against any civilian population, with knowledge of the attack: (a) ... (f) Torture; (g) ...

The Statute, also, gives a definition of torture for in another part of article 7:

"...(e) "Torture" means the intentional infliction of severe pain or suffering, whether physical or mental, upon a person in the custody or under the control of the accused; except that torture shall not include pain or suffering arising only from, inherent in or incidental to, lawful sanctions;"

Most international crimes are assumed to be committed in armed conflict context, either internally or internationally, but torture and genocide, according to their related conventions, do not require a context of armed conflict. Torture, in order to be treated as an international crime, requires an important link between an individual and a state. ${ }^{193} \mathrm{It}$ is now strongly accepted as a rule of customary international law that a connection to an international armed conflict or even any conflict at all, is not a factor in the definition of crimes against humanity. ${ }^{194}$

Torture is among these crimes, which can occur out of a systemic plan or policy of the state. An official may practice torture against orders but under color of law. ${ }^{195}$ Again, the case against Chilean Pinochet ${ }^{196}$ opened a new discussion and debate about

\footnotetext{
${ }^{191}$ For more information see: Henry J. Steiner \& Philip Alston, supra note 86 at 1176.

${ }^{192}$ Rome Statute of the International Criminal Court, U.N. Doc. A/CONF.183/9, U.N.T.S. 3, Nov. 10, 1998 entered into force July 12, 1999, online (UN website): http://www.un.org/law/icc/statute/romefra.htm

${ }^{193}$ Henry J. Steiner \& Philip Alston, supra note 86 at 1137.

${ }^{194}$ Appeals Chamber, International Criminal Tribunal for the former Yugoslavia, 1995 Case No. IT-94-1AR72, Oct. 2, 1995; Cited in: Henry J. Steiner \& Philip Alston, supra note 87 at 1167; for more information see: Faiza Patel King and Anne-Marie La Rosa, The Jurisprudence of the Yugoslavia Tribunal: 1994-1996, European Journal of International Law, Vol.8 (1997), No.1 at 123, online; EJIL Website: http://www.ejil.org/journal/Vol8/Nol/srl.html ${ }^{195}$ Henry J. Steiner \& Philip Alston, supra note 86 at 1137.

${ }^{196}$ General Pinochet, former president of Chile was facing accusation of violation of Human Rights during his reign when he traveled to UK for medical treatment in 1998. The judiciary of Spain sought to extradite him to stand criminal trial in Spain because of committing crimes against humanity including conspiracy to
} 
torture, and provided rich legal literature in this regard all over the world. ${ }^{197}$ It is clear that torturers are facing fear of being extradited or prosecuted for what they've done.

In 1996, the International Law Commission created by the UN General Assembly provided the international community with a "Draft Code of Crimes Against the Peace and Security of Mankind." This document counted crimes against humanity in article 18, including torture. This draft is based on existing customary law. ${ }^{198}$

There are, also, a number of $\mathrm{UN}$ documents related to the question of helping victims of torture such as the UN Resolution on the United Nations Voluntary Fund for Victims of Torture. ${ }^{199}$ This document noted with deep concern that acts of torture took place in various countries, recognized the need to provide assistance to the victims in a purely humanitarian spirit and established the United Nations Voluntary Fund for Victims of Torture. The Vienna Declaration and Program of Action ${ }^{200}$, adopted by the World Conference on Human Rights on 25 June 1993 recommended that high priority should be given to provision of the necessary resources to assistance to victims of torture and effective remedies for their physical, psychological and social rehabilitation.

The efforts of NGOs such as Amnesty International to provide reports on torture and releasing news on the practicing torture all over the world have played an important role in combating torture. ${ }^{201}$ The International Committee of the Red Cross (ICRC) ${ }^{202}$ and the Association for Prevention of Torture (APT) ${ }^{203}$ have also played effective roles to take steps to prevent torture in International Law.

torture between 1972 and 1990. For more information about his case see: Henry J. Steiner \& Philip Alston, supra note 86 at $1199-1203$.

${ }^{197}$ Henry J. Steiner \& Philip Alston, supra note 86 at 1199-1203.

${ }^{198}$ For more information see: Henry J. Steiner \& Philip Alston, supra note 86 at 1135.

${ }^{199}$ United Nations Voluntary Fund for Victims of Torture, UNGA Res. A/RES/36/151, 16 December 1981, online (UN website): http://www.un.org/documents/ga/res/36/a36r151.htm

${ }^{200}$ The Vienna Declaration and Program of Action, UNGA Res. A/CONF.157/23, 12 July 1993, online (UN website):

http://www.unhchr.ch/huridocda/huridoca.nsf/(Symbol)/A.CONF.157.23.En?OpenDocument

${ }^{201}$ For example see: supra note 169.

${ }^{202}$ For more information see: walter Kälin, The struggle against torture, International Review of the Red Cross no 324, 30-09-1998, 433-444, online (ICRC website): http://www.icrc.org/Web/Eng/siteeng0.nsf/iwpList74/1F8493053DA4F105Cl256B66005C43BC

${ }^{203}$ The Association for the Prevention of Torture (APT) is an independent non-governmental organization working worldwide to prevent torture and ill-treatment founded in 1977, by Jean-Jacques Gautier and based in Geneva, Switzerland, for more information see: http://www.apt.ch/ 


\section{Chapter 4: The Definition of Torture and other Cruel, Inhuman and Degrading Treatment or Punishment in International Law}

The dilemma of what constitutes torture has been important to the global fight to eliminate torture. The UN Declaration on the Protection of All Persons from Being Subjected to Torture and Other Cruel, Inhuman or Degrading Treatment or Punishment (Declaration against Torture) of $1975^{204}$, gave for the first time in an international document a detailed definition of torture. Article 1 of the Declaration states:

"I. For the purpose of this Declaration, torture means any act by which
severe pain or suffering, whether physical or mental, is intentionally
inflicted by or at the instigation of a public official on a person for such
purposes as obtaining from him or a third person information or
confession, punishing him for an act he has committed or is suspected
of having committed, or intimidating him or other persons. It does not
include pain or suffering arising only from, inherent in or incidental to,
lawful sanctions to the extent consistent with the Standard Minimum
Rules for the Treatment of Prisoners.

2. Torture constitutes an aggravated and deliberate form of cruel, inhuman or degrading treatment or punishment." (emphasis added)

The elements of the given definition can be recognized as:

- The act of inflicting pain or suffering physically or mentally;

- Done by a public official intentionally;

- In order to:
- Obtain information or confession from the victim or a third person
- Punishing the victim
- Intimidating the victim or others.

This article excludes pain or suffering arising from lawful sanctions, as will be later discussed. ${ }^{205}$

The basic definition of torture is contained in the Convention against Torture and Other

\footnotetext{
${ }^{204}$ Supra note 121.

${ }^{205}$ See below: 4.2 .
} 
Cruel, Inhuman or Degrading Treatment or Punishment ${ }^{206}$ of December 10, 1984. It is very close to the definition delivered by the UN Declaration against Torture; however, the Convention definition is more complete. The Convention definition, however, does not point to the relation between torture and other cruel, inhuman or degrading treatment and punishment. The convention in article 1 states:

"1. For the purposes of this Convention, the term "torture" means any act by which severe pain or suffering, whether physical or mental, is intentionally inflicted on a person for such purposes as obtaining from him or a third person information or a confession, punishing him for an act he or a third person has committed or is suspected of having committed, or intimidating or coercing him or a third person, or for any reason based on discrimination of any kind, when such pain or suffering is inflicted by or at the instigation of or with the consent or acquiescence of a public official or other person acting in an official capacity. It does not include pain or suffering arising only from, inherent in or incidental to lawful sanctions.

2. This article is without prejudice to any international instrument or national legislation which does or may contain provisions of wider application."

From the definition of the UN Convention Against Torture, a number of elements required for an incident to be legally considered a case of torture can be extracted. These elements may be recalled as follows:

- The act of inflicting pain or suffering physically or mentally;

- Done intentionally by or at the instigation of or with the consent or acquiescence of a public official or other person act in an official capacity

- In order to:

- Obtain information or confession from the victim or a third person

- Punishing the victim

- Intimidating the victim or a third person

- Coercing the victim or a third person

- For any reason based on discrimination of any kind.

${ }^{206}$ Supra note 32. 
The act of torture may be positive or negative. That is to say that it may be an action to inflict pain or suffering, like beating the victim, or, it may be depriving the victim of necessary food or medicines. ${ }^{207}$ Under law, it is of course also necessary to find a causal relationship between what the torturer does or does not do, and the pain and suffering of the victim. ${ }^{208}$

Both of the definitions are silent about the personality of the victim. Although it is clear that both the UN Declaration against Torture and as the Convention against Torture try to provide safeguards for those who are in detention or are imprisoned, it seems that it is not necessary for the victim to be under detention or imprisonment. ${ }^{209}$

It is clear that these two definitions have much in common. The Convention definition, however, is broader and spreads the responsibility of officials. It counts more possible purposes for torturing people as an important element constitute the crime of torture. The list of purposes is not all-inclusive but indicative. It means that if someone was subjected to severe pain or suffering for some other possible purposes beyond what is enumerated in this article, it still falls under definition of torture. ${ }^{210}$

Based on the Convention definition, the responsibility of public officials is wider. Public officials are responsible, if torture happened at their instigation or with their consent or acquiescence, or even if they do not commit torture, but ordered someone else to do so. Such a wide definition does not allow some of the high ranking officials to deny their responsibility. ${ }^{211}$ Even someone who is not a public official but acts in an official capacity is responsible. This part of the definition provides the opportunity to prosecute torturers who are not officially members of the police or judiciary. ${ }^{212}$ For example, the Committee against Torture, in its Communication No. $120 / 1998,{ }^{213}$ stated that some of

\footnotetext{
${ }^{207}$ Supra note 136 at 3.

${ }^{208}$ Ibid.

${ }^{209}$ Ibid.

210 Supra note 138at 21.

${ }^{211}$ See: supra note 150 at 120.

${ }^{212}$ For example: in Iran one of the powerful unofficial forces is ANSARE HEZBOLLAH who attacks people, arrests them and sometimes interrogates them. They use torture in their daily acts.

${ }^{213}$ Communication No. 120/1998: Australia, Committee Against Torture, Sess. $22^{\text {nd }}$, UN Doc.

CAT/C/22/D/120/1998, 25 may 1999, para. 6.5, online (UNHCHR website):
} 
the factions operating in Mogadishu set up quasi-governmental institutions whose operations were comparable to those normally exercised by legitimate governments. Accordingly, the members of those factions can fall within the phrase of "public official or other person acting in an official capacity" mentioned in article 1 of the Convention. If officials act under their private capacities, it does not fall within the definition of torture based on the Committee against Torture Communication No. 120/1998 while it is torture with regard to the Paragraph 2 of the Human Rights Committee General Comment no. 20 on article 7 of the ICCPR ${ }^{214}$. However, committing torture acting under their private capacity, at least, can be the subject of national legislations under some other criminal titles. $^{215}$

The question of law sanctions has also been mentioned. In addition, the article does not prevent wider application of the article in national or international law. This is logical, as wider applications of the definition would mean less possibility of the occurrence of torture - or at least that more heinous acts would fall within the definition. ${ }^{216}$

The Rome Statute of the International Criminal Court, $1998,{ }^{217}$ also provides a definition on the torture. Article 7 oft the Rome Statute states that torture is among crimes against humanity. For the purposes of the article 7(2):

"Torture means the intentional infliction of severe pain or suffering, whether physical or mental, upon a person in the custody or under the control of the accused; except that torture shall not include pain or suffering arising only from, inherent in or incidental to, lawful sanctions"

Considering that torture here is a crime against humanity when it is committed as part of a widespread or systematic attack directed against any civilian population, the torturer need not necessarily be a public official or someone who acts in an official capacity. It may also be a soldier or a military official or even a civilian with no position.

http://www.unhchr.ch/tbs/doc.nsf/385c2add1632f4a8c12565a9004dc311/b054cbf1e34a6c278025679a003c 37ec?OpenDocument

${ }^{214}$ Supra note 105.

${ }^{215}$ See: supra note 136 at 3.

${ }^{216}$ Supra note 143 at 2.

${ }^{217}$ Supra note 192. 


\section{Section 4.1: Torture: A Type of Cruel, Inhuman or Degrading Treatment or} Punishment

According to Article 1 of the UN Declaration against Torture, ${ }^{218}$ torture is a more serious form of cruel, inhuman or degrading treatment or punishment. It states that "Torture constitutes an aggravated and deliberate form of cruel, inhuman or degrading treatment or punishment." 219

While torture has been defined in both the UN Declaration Against Torture and the UN Convention against Torture, neither provides a definition of cruel, inhuman or degrading treatment or punishment.

Article 1 of the UN Convention, uses only the word torture in its text, suggesting that this distinction between torture and other forms of cruel, inhuman and degrading treatment or punishment was not an issue; torture is just one form of many unjust abuses. ${ }^{220}$

Torture is an emotive word, characterized by and distinguished from other forms of illtreatment by the severity of suffering it implies. It is important, therefore, to reserve the term for the most objectively serious forms of ill-treatment. "Cruel treatment, and inhuman or degrading treatment or punishment" are also legal terms, and refer to illtreatment causing varying degrees of suffering which are less severe than torture. ${ }^{221}$

Article 1 of the Convention Against Torture suggests that unlike torture, to qualify as inhuman or degrading treatment or punishment, an act does not need to be executed for the specific purpose of obtaining information or a confession. However, if the inhuman or degrading treatment or punishment is carried out for the purpose of obtaining information or a confession, then it constitutes torture. Torture is therefore necessarily a form of cruel, inhuman or degrading treatment or punishment, but not all forms of cruel inhuman or degrading treatment or punishment constitute torture. ${ }^{222}$

\footnotetext{
218 Supra note 121.

${ }^{219}$ Article 1(2) of the UN Declaration against Torture, Supra note 121.

${ }^{220}$ Nagan, Winston \& Atkins, Luice, supra note 11 at 84.

${ }^{221}$ Camille Giffard, The Torture Reporting Handbook, (Clochester: Human Rights Center, University of Essex, 2000) at 12.

${ }^{222}$ See: Nagan, Winston \& Atkins, Luice, supra note 11 at 58.
} 
Other elements of the crime of torture, namely, inflicting some degrees of pain and suffering and being done by public officials intentionally, can be taken into account as elements of other cruel, inhuman or degrading treatment or punishment. ${ }^{223}$

When contemplating a definition for torture, it is important to remember that it is also a very personal experience. The degree of suffering will vary from person to person, depending on such factors as the age of the victim, sex, religious beliefs, cultural background and health. ${ }^{224}$

Mr. Peter Koojimans, the first Special Rapporteur on torture counted some examples of torture and other cruel, inhuman or degrading treatment and punishment in his 1986 report. Beating, extraction of nails or teeth, burns, electric shocks, suspension, suffocation, exposure to excessive light or noise, sexual aggression, denial of rest or sleep, prolonged denial of food or sufficient hygiene or medical assistance, total isolation and sensory deprivation, being kept in constant uncertainty in terms of space and time, threats to torture or kill relatives, total abandonment and simulated execution are among sufferings that constitute torture. ${ }^{225}$

Mr. Koojimans also described a "grey area" ${ }^{226}$ of controversial sorts of torture. Examples include corporal punishment imposed as a judicial penalty, some forms of capital punishment and the death-row phenomenon, solitary confinement, aspects of poor prison conditions particularly if combined, disappearances, including their effect on the close relatives of the disappeared person, and treatment inflicted on a child which might not be considered torture if inflicted on an adult. Whether these acts are considered torture or some other form of cruel, inhuman or degrading treatment is contingent on many factors. To help make this distinction, the European Court of Human Rights has developed criteria to differentiate torture from other forms of cruel treatment. The criteria are based on severity, the intention of the official, and a principle of respect for human dignity:

\footnotetext{
${ }^{223}$ Supra note 221 at 13.

${ }^{224}$ See: Lene Wendland, $A$ handbook on State Obligations under the UN Convention against Torture, (Geneva: APT Publication, 2002) at 24.

${ }^{225}$ Peter Koojimans, Torture and other Cruel, Inhuman and Degrading Treatment or Punishment, Report of the Special Rapporteur, February 19, 1986, UN Doc. E/CN.4/1986/15, para. 29, on line (UN website): http://daccess-ods.un.org/access.nsf/Get?Open\&DS=E/CN.4/1986/15\&Lang=E

${ }^{226} \mathrm{Ibid}$, para. 33.
} 
Severity: If the force of the violence and the physical or moral suffering have led to a "threshold of severity" it qualifies as torture. This criterion has been used in several cases. Among these is the 1976 case of Ireland $v$. United Kingdom. ${ }^{227}$ In this case, the European Court gave a very detailed distinction between torture and degrading and inhuman treatment or punishment. The suffering caused by torture, inhuman or degrading treatment is a distinctive factor, and when such a treatment results in extremely serious suffering, it can be qualified as torture. Unfortunately, the definition of "extremely serious suffering" was not clear in this decision. In another case, Selmouni v. France ${ }^{228}$. decided on July 28,1999 , at issue was maltreatment suffered by the applicant while in police custody. The questionable conduct included punching, striking with a baseball bat, spraying with urine, using blow-torches to burn feet, and threatening with a syringe. The Court condemned France for acts of torture. The Court also considered that certain acts which were classified in the past as 'inhuman and degrading treatment' as opposed to 'torture' could in the future be classified differently in response to increased standards for the protection of human rights and fundamental liberties. This acknowledgement by the court suggests that those acts formerly considered forms of cruel, inhuman and degrading treatment, are now attributed greater consequence, and are considered forms of torture under international law.

The intentions of officials: As a second criterion for distinguishing torture from other acts, the deliberate intent to violate the human dignity of the person, or to force a

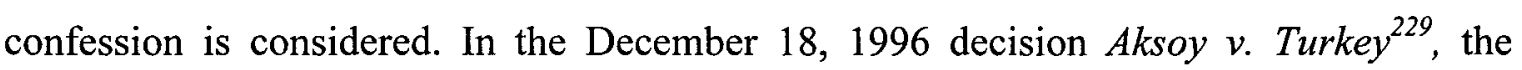
applicant was arrested and placed in custody where he suffered from several forms of torture. This case marks the first condemnation of a State by the European Court of Human Rights for acts of torture:

In the view of the Court this treatment ... could only have been deliberately inflicted (...). It would appear to have been administered with the aim of obtaining admissions or information from the applicant. In addition to the severe pain which it must have caused at the time, the medical evidence

\footnotetext{
${ }^{227}$ Ireland v. The United Kingdom, (5310/71) [1978] ECHR 1 (18 January 1978), 66-67, online: http://www.worldlii.org/eu/cases/ECHR/1978/1.html

${ }^{228}$ Selmouni v. France, European Court of Human Rights, Case no. 25803/94, [1999] ECHR 66 (28 July 1999), online: http://www.worldlii.org/eu/cases/ECHR/1999/66.html

${ }^{229}$ Aksoy v. Turkey,supra note 44.
} 
shows that it led to a paralysis of both arms which lasted for some time (...). The Court considers that this treatment was of such a serious and cruel nature that it can only be described as torture. (Emphasis added).

The principle of respect for human dignity: In the 1992 case of Tomasi v. France, ${ }^{230}$ the applicant brought before the court several provisions of the Convention, notably Article 3, concerning the maltreatment during police custody. In response, the Court emphasized the absolute nature of the protection provided by the article:

"It finds it sufficient to observe that the medical certificates and reports, drawn up in total independence by medical practitioners, attest to the large number of blows inflicted on Mr. Tomasi and their intensity; these are two elements which are sufficiently serious to render such treatment inhuman and degrading. The requirements of the investigation and the undeniable difficulties inherent in the fight against crime, particularly with regard to terrorism, cannot result in limits being placed on the protection to be afforded in respect of the physical integrity of individuals." 231

Judge Meyer in this case formulated a principled opinion in this case:

"Any use of physical force in respect of a person deprived of his liberty which is not made strictly necessary as a result of his own conduct violates human dignity and must therefore be regarded as a breach of the right guaranteed under Article 3 of the Convention. At the most the severity of the treatment is relevant in determining, where appropriate, whether there has been torture."

\section{Section 4.2: Lawful Sanctions and the question of corporal punishments}

Pain and suffering are excluded from the definition of torture when they arise from, are inherent in, or incidental to a lawful sanction. For example, the suffering from being in jail and deprived from liberty cannot be defined as torture.

\footnotetext{
${ }^{230}$ Tomasi v. France, (12850/87) [1992] ECHR 53 (27 August 1992), online: http://www.worldlii.org/eu/cases/ECHR/1992/53.html

${ }^{231}$ Ibid, para 120.
} 
Article 1 of the UN Declaration against Torture ${ }^{232}$ proposes that the Standard Minimum Rules for the Treatment of Prisoners be used as a criterion for recognizing lawful sanctions. $^{233}$ It seems that the drafters of the Declaration were thinking only of imprisonment as a lawful sanction.

The Convention Against Torture ${ }^{234}$ also excludes from the definition of torture pain or suffering arising from lawful sanctions, but does not give any criteria to determine what these lawful sanctions are. The only sensible interpretation of this provision is that such sanctions would not be lawful if their purpose was wrongful - punishment, intimidation, getting a confession or any one of the prohibited reasons. ${ }^{235}$ Addressing this issue in his 1997 report, ${ }^{236}$ former Special Rapporteur Mr. Nigel Rodley states that:

"The "lawful Sanctions" exclusion must necessarily refer to those sanctions that constitute practices widely accepted as legitimate by the international community, such as deprivation of liberty through imprisonment, which is common to almost all penal systems."

In the same report, Mr. Rodley discussed the question of corporal punishments such as flogging, stoning and amputation in some Islamic countries. He argues that any corporal punishment falls under the prohibition of torture and other cruel, inhuman or degrading treatment or punishment. ${ }^{237} \mathrm{He}$ further refused the idea of some governments and legal experts that corporal punishment should not be considered as torture, considering the fact that these punishments are prescribed under national law and are carried out by states and are "lawful sanctions." 238 If such a justification is accepted, any physical punishment, no matter how torturous and cruel, would be considered lawful as long as it is in accordance with domestic law. This logic is of

\footnotetext{
${ }^{232}$ Supra note 121.

${ }^{233}$ Supra note116.

${ }^{234}$ Supra note 32.

${ }^{235}$ See: supra note 224 at 29.

${ }^{236}$ Nigel Rodley, Torture and other Cruel, Inhuman and Degrading Treatment or Punishment, Report of the Special Rapporteur, Mr., Sess. 53 ${ }^{\text {th }}, 10$ Jan. 1997, UN Doc. E/CN.4/1997/7, para. 8, on line (UN website): http://ods-dds-ny.un.org/doc/UNDOC/GEN/G97/101/13/PDF/G9710113.pdf?OpenElement

${ }^{237}$ Ibid, para. 6.

${ }^{238}$ Ibid, para. 7.
} 
course unacceptable under international law, which bans all kinds of torture, cruel, inhuman or degrading treatment or punishment. ${ }^{239}$

In his 1997 report, Mr. Rodley further recognizes that the existing corporal punishments in domestic laws are often derived from the religious law in which the given nation is rooted. At the same time, he notes that there exists a great divergence of views among Islamic scholars and clerics concerning the obligations of the states to implement corporal punishments. ${ }^{240}$ The Human Rights Committee in General Comment no. $20^{241}$ stressed that corporal punishments including excessive chastisement ordered as punishment for a crime or as an educative or disciplinary measure fall within the prohibition of torture based on article 7 of the ICCPR ${ }^{242}$. The following chapter will explore the question in Islam.

\footnotetext{
${ }^{239}$ Ibid, para. 8 .

${ }^{240}$ Ibid, para. 10.

241 Supra note 105.

${ }^{242}$ Supra note 36.
} 


\section{Chapter 5: An Examination of Torture in Islam}

Shia is a branch of Islam, and a dominant religion in Iran. The leaders of the Islamic Republic of Iran proclaim that they follow Shia jurisprudence. This section examines Islamic teachings relying on Shia sources, and comments of Shia high ranking clerics. It should be prefaced that all branches of Islam accept the content of the Koran, though it may be interpreted in different ways. I use only the Shia interpretation in this thesis.

\section{Section 5.1: Corporal Punishments are not Torture}

Given the definition of torture by international law, corporal punishment falls within the definition of torture. ${ }^{243}$ It cannot be ignored that there are some corporal punishments ${ }^{244}$, namely, Hodood ${ }^{245}$, Qisas $^{246}$ and Tazirat ${ }^{247}$ in Islam, covered by the modern definition of torture. ${ }^{248}$ Thus, as Islam accepts corporal punishment under certain conditions, Islam may be accused of being in opposition to Human Rights law.

They cannot be excluded from the definition of torture as "lawful sanctions" ${ }^{\text {, } 49}$ regardless

\footnotetext{
${ }^{243}$ See above: 4.2 .

${ }^{244}$ For more information about Islamic Punishments and their definitions in Shia faith see: Mohammad Ebrahim Shams Nateri, A Comparative Study on Capital Punishment, $1^{\text {st }}$ ed., (Qom: Islamic Propagation of the Qom Seminary Publications, 1999) at 82 \& 158.

${ }^{245}$ Hodood is a plural word for Hadd. It is an Islamic corporal punishment which applies to certain crimes like adultery, sodomy, robbery, drinking alcohol etc. It may appear in the shape of flogging specific amount of lashes, stoning and so on. For example: punishments for adultary are 100 lashes and stoning in some cases and for the offence of drinking the punishment is 75 lashes. See: Ayatollah Montazeri, Resaleh Amalieh, paras $3154-3177$, available online (Montazeri website): http://www.montazeri.ws/Farsi/Resaleh/html/0020.htm\#0358

${ }^{246}$ Qisas means retaliation. In crimes against one's body the criminal may be punished by retaliation. It may appear in shape of execution or amputation. For example, if the crime is capable of being retaliated. For example the murderer will be killed, the ear of some one who cut another person's ear will be cut in the same way. See: Ayatollah Montazeri, Resaleh Amalieh, paras 3228 - 3239, available online (Montazeri website): http://www.montazeri.ws/Farsi/Resaleh/html/0020.htm\#0372

${ }^{247}$ Tazirat is a plural word for Tazir. It is a less sever punishment which applies to minor crimes whose punishment is not Qisas or Hadd. Tazir may appear as flogging or sending to exile etc. but it is all in the hands of the judge. There is no specific guideline to apply it. An Islamic judge may punish a person for his sin to God if it is not among the crimes capable of being punished by Qisas or Hodood with punishment lighter than Hodood. See: Ayatollah Montazeri, Resaleh Amalieh, paras 3178 - 31202, available online (Montazeri website): http://www.montazeri.ws/Farsi/Resaleh/htm1/0020.htm\#0358

${ }^{248}$ See: Mohsen Kadivar, Human Rights and Religious Intellectualism, Aftab Monthly, Vol. 28, August 2003, at 106, online; Kadivar website: http://www.kadivar.com/Htm/Farsi/Interviews/Aftab-27-28.pdf

${ }^{249}$ See below: 4.2 .
} 
of the fact that the brutal punishments may apply to the accused people only after trial by a qualified judge ${ }^{250}$ and convicted according to specific rules in order to punish them ${ }^{251}$ and there are no other purposes such as to make the accused confess or to extract more information. ${ }^{252}$

Some Islamic lawyers ${ }^{253}$ strongly challenge the application of the international definition to explain the conflict but, as we will discuss later in this chapter, ${ }^{254}$ others believe that these corporal punishments can be left aside, considering the values of humanity expressed in international law, and the supportive spirit of Islam towards human rights.

Regardless of the controversial area of corporal punishment, Islamic teachings condemn inflicting suffering and pain on a person no matter how severe it is. At least, there is no doubt that degrading, inhuman treatment, and torture of detainees before trial is absolutely banned in Islam, and none of the Shia clergy challenge such a ban. ${ }^{255}$ There are lots of stories about Imam Ali's judgments. ${ }^{256}$ Imam Ali was the first man who accepted Islam in the world and he is the second holy man after Prophet Mohammad in Shia faith. His judgments show that interrogation in Islam is not to be based on torture. Judges should find the truth through careful investigation of all evidence and through asking detailed questions to gain full testimony. ${ }^{257}$

According to Islamic scholars, torturing a detainee is not allowed, firstly because even if a truth can be revealed by torture it is better that it remain hidden than to violate an

\footnotetext{
${ }^{250}$ In order to protect people's rights, in Islam, one who wants to serve as a judge must meet a series of very specific criteria and qualifications. He must be brave, patient, faithful, trustable, wise etc. For more information see: S. Esmail Rasoolzadeh, Imam Ali's Judgments, (Tehran: Dehghan Publishing, 1984) at 491.

${ }^{251}$ Hussein Ali Montazeri, "Replying to the Questions About Tolerance and Violence" in Views, Aug. 6, 1999, at 15. online; Montazeri web site: www.montazeri.ws

252 Torturers' attempt in Islamic countries, especially in Iran, to abuse the Islamic concept of Tazir to justify their behaviors is not in accordance with Islam; see: Reza Afshari, supra note 48, at 49 .

${ }^{253}$ Hussein Mehrpoor, Supra note 100 at 36; also see: Nigel Rodley, Torture and other Cruel, Inhuman and Degrading Treatment or Punishment, Report of the Special Rapporteur, supra note 236, para. 6, on line (UN website): http://ods-dds-ny.un.org/doc/UNDOC/GEN/G97/101/13/PDF/G9710113.pdf?OpenElement ${ }^{254}$ See below: 4.2 .

${ }^{255}$ Muhammad Shirazi, Rights of Prisoners According to IIslamic Teachings, $1^{\text {st }}$ ed. (London, 2002) at 24 online; Shirazi Website: http://www.shirazi.org.uk/prisoner2.htm\# Toc16920217 ; also see: An Interview with Naser Ghavami, the head of judicial committee of Parliament, Iran Kar Press Agency, Monday Oct. 27, 2003; online Gooya Website: http://news.gooya.com/politics/archives/001025.php

${ }^{256}$ To see samples of Imam Ali's Judgment see: S. Esmail Rasoolzadeh, supra note 250.

${ }^{257}$ Muhammad Shirazi, Supra note 255.
} 
individual's dignity. Secondly, even if you torture a detainee, there is no guarantee the truth will be revealed as he may confess to something untrue to put an end to the pain. ${ }^{258}$ Ayatollah Shirazi has mentioned a number of methods to reveal the truth, which have been used by Islamic judges throughout history, such as the rule of repetition and doubt, twist and turn, probing and examination, and finally, insight and astuteness. ${ }^{259}$

This strong position against torture among Islamic scholars is based on the Koran and other sources that respect human beings. ${ }^{260}$ The holy Koran paid special attention to the dignity and integrity of people. ${ }^{261}$ This issue has been pointed out in different verses such as verse 70 of Sura Al-Asra:

"Indeed, we honored the children of Adam; provided them with means of transportation on land and sea; and also provided them lawful and pure sustenance and preferred them above many of our creatures" 262

Khajeh Abdollah Ansari, in his interpretation on this verse of the Koran, states that God endowed the human being with a kind of quality and great dignity. ${ }^{263}$ Ayatollah Tabatabaee, an Islamic cleric who was a specialist in Koran interpretation, stipulates that the purpose of this verse is to appreciate all human beings. All humans are respected by God and hold dignity, regardless of their beliefs. ${ }^{264}$

Ayatollah Javadi Amoli, a high ranking extremist cleric, believes that in the eyes of God, the human being is honored and is filled with qualities above all other creatures. Human beings are superior to all creatures, and, when man was created, God asked the angels to

\footnotetext{
${ }^{258}$ Muhammad Shirazi, Supra note 255; also see Montazeri's comment during the assessment of Iranian Constitution: The Entire Negotiations During the Final Assessing of the Islamic Republic of Iran Constitution, Vol. 1, (Tehran: Parliament Publishing, 1981) at 619-20.

${ }^{259}$ Muhammad Shirazi, Supra note 255 at 25.

${ }^{260}$ Emadodin Baghi, Legitimizing Torture, Yaseno Daily, Dec. 2, 2003, at 1; online, Baghi website: http://www.emadbaghi.com/archives/000127.php

${ }^{261}$ For more information see: Reza Feiz, "Human Dignity in Ibn-Arabi's Irfan" in International Human Rights and Negotiations Among Civilizations Seminar-Articles Collection" ed. Mofid University Administration, (Qom: Mofid University Publishing, 2001) 195-210 at 198; also see: Mohamad Taghi Jafari Tabrizi, Research On two system of human Rights: Islamic and Western, (Tehran: Office of International Legal Services, 1991) at 100.

262 "Holy Koran", Surah Al-Asra, Verse No. 70, (Tehran: Ershad Printing, 2001) at 663.

${ }^{263}$ Habibollah Amoozgar, Spiritual and Literal Koran Interpretations of Khajeh Abdollah Ansari, $7^{\text {th }} \mathrm{ed}$. (Tehran: Eghbal Publishing, 2000) at 576.

${ }^{264}$ Mohammad Hussein Tabatabaee, "Al-Mizan in Koran Interepretation" Vol.13, $3^{\text {rd }}$ ed., (Beirut: Alami Publishing, 1989) at 152.
} 
worship him. ${ }^{265}$ Some of the young religious thinkers ${ }^{266}$ invoke this verse to discuss that Islam supports even Humanism. They invoke, also, another verse of the holy Koran that is a conversation between God and the angels. It reads, "...I will appoint a divine governor $^{267}$ on the earth. Do you appoint a kind of creature who will make mischief therein and shed blood?... God stated, indeed I know what you do not know." 268 Ayatollah Hussein Ali Montazeri ${ }^{269}$ believes that human beings must be respected simply because we are human, and nobody should violate humans' rights. He recently stated that the above-mentioned verses of the Koran precisely emphasize that human beings are equal, regardless of their beliefs. God himself respects humanity, so how is it possible to ignore God's will? He recalls a saying from Imam Ali, the first Muslim in the world after Muhammad, when he advised Malik, the appointed governor to Egypt, in a famous letter ${ }^{270}$, to open his heart as a source of love and mercy to people who are either his brothers in religion or the same as him in creation, and to treat them with fairness. ${ }^{271}$ Montazeri, in his famous book, Basis of Islamic Government in Islamic Jurisprudence, which is considered the basis for establishing Islamic Shia government in Iran, states that any kind of torture used against a detainee who is accused of a crime is aggression and illegitimate violence, which are forbidden strongly in Islam. ${ }^{272} \mathrm{He}$ comes up with some reasons to support his idea. First, torture is against public consciousness; ordinary people in society do not support it. Second, it is against the Islamic rule of Soltah which says everybody has authority on his own body and no one can interfere without permission. Third, the Islamic rule of Baraah, which says everybody must be assumed innocent,

\footnotetext{
${ }^{265}$ For example see: Abdollah Javadi Amoli, "Philosophy of Human Rights" $2^{\text {nd }}$ ed. (Qom, Iran: Asra Publishing, 1998) at162.

${ }^{266}$ Emadodin Baghi, Human Rights or Believers' Rights, Shargh Daily, Tuesday Dec. 2, 2003, at 1; online, Baghi website: http://www.emadbaghi.com/archives/000124.php\#more

${ }^{267}$ Khalifa, in some English texts translated as "Substitute"

268 "Holy Koran", Surah Al-Bagharah, Verse No. 30, (Tehran: Ershad Printing, 2001) at 13.

${ }^{269}$ Hussein Ali Montazeri, "Basis of Islamic Government in Islamic Jurisprudence", Vol.3, $1^{\text {st }}$ ed., (Tehran: Tafakor Publishing, 1991) at 573-4.

${ }^{270}$ Imam Ali Ben Abitalib, Nahj-ol-Balaghah, letter no. 53 (Letter to Malik Ashtar), Para 15-17, online; Islamic Propaganda Organization web site: http://www.tebyan.net/MaarefEslami/Maarefmain.asp?URL=vasete/nahjolbalage.asp

${ }^{271}$ Emadoddin Baghi, Reports on Shia Jurisprudence Courses by Ayatollah Montazeri from Sep. 21, 2003 to Oct, 10, 2003, Online, Baghi Website: http://www.emadbaghi.com/archives/000125.php

${ }^{272}$ Supra 269.
} 
explains that torturing an accused before trial is punishment of the innocent. Fourth, teachings from the prophet Mohammad and Imams, such as a Hadith from the prophet Mohammad which says; "God will torture in judgement day a man who has tortured people during his life" 273 .

Montazeri also believes that during the interrogation, the interrogator must be careful to behave humanely. He believes that interrogation during the night is not acceptable in Islam. $^{274}$

Islam invalidates all confession and testimonies made under pressure or torture. ${ }^{275}$ All high-ranking clergies are of the opinion that such confessions cannot be used against the accused by a judge. ${ }^{276}$ Imam Ali says; "If someone confesses a crime after being frightened, detained or threatened, he cannot be punished" 277.

Ayatollah Makarem Shirazi, another high-ranking clergyman (Marja), says that torture is forbidden, and that the confession made under torture is not valid. He recalls a story about a thief who confessed after being tortured. Imam Ali was informed of the story and said that the thief's confession had no value, and he must thus be released as such a confession can have no validity. ${ }^{278}$

The Khobregan Assembly, whose mandate was to provide an Islamic Constitution, contained all high-ranking clergymen. The outcome of such an assembly, as we discusse later $^{279}$, is Article 38 of the Iranian Islamic Constitution. Moreover, a study of the negotiations illustrates how Shia jurisprudence refuses torture. ${ }^{280}$

\footnotetext{
${ }^{273}$ Cited in: Hussein Ali Montazeri, Supra note 269 at 574.

${ }^{274}$ Hussein Ali Montazeri, supra note 251 at 51.

${ }^{275}$ Hussein Ali Montazeri, Supra note 269 at 577.

${ }^{276}$ Emadodin Baghi, Supra note 260.

${ }^{277}$ Horr Ameli, Vasael-Al-Shia, vol.18, at 497 cited in: Emadodin Baghi, supra note 260.

${ }^{278}$ Naser Makarem Shirazi, Anvar-Al-Feghaha: Hodood \& Tazirat Book, Vol.1, $1^{\text {st }}$ ed., (Tehran: Imam Ali School Publishing, 1996) at136-7.

${ }^{279}$ See sub-section 6.3.5.

${ }^{280}$ Emadodin Baghi, Supra note 260.
} 
Section 5.2: Modern reading of Islamic (Shia) jurisprudence to reconcile Islamic teachings with Human Rights Values

Unfortunately, the traditional and sometimes fundamental Islamic point of view is more known to academics and human rights activists in Western countries than moderate and modern ideas. However, I believe that such a point of view does not represent the Islamic view as a whole. In recent years, some new ideas were suggested by a new generation of Iranian Shia clerics. These ideas challenged the old view of absolute refusal of human rights as Western values and non-Islamic or even anti- Islamic notions. Analyzing these ideas seems to be beneficial to understand the position of Islam, or at least the Shia faith, with respect to the question of torture. Shia faith is more apt to welcome new ideas than other Islamic sects due to specific criteria of the faith, such as:

1. Accepting "reason" as a source to recover God's will;

2. Accepting the dynamic Ijtihad ${ }^{281}$, which means it is possible to reveal God's will in new cases, and revise old rules if necessary;

3. Considering justice as one of the qualities of God, as well as a criterion to examine religious rules. ${ }^{282}$ If a rule is against justice it cannot be acknowledged by God, Who supports absolute justice.

Recently, some modern readings of Islam have emerged versus a traditional and fundamental reading of Islam. These new debates can be treated as the outcome of experiencing the Islamic government in the last 25 years in Iran.

One of the almost new ideas is the idea of "Ijtihad in accordance with the time and place we live (Dynamic Ijtihad v. Static Ijtihad)". Ijtihad is an old traditional concept which is accepted in Shia Faith and can be considered as a privilege for Shia faith.

According to this concept, a qualified clergyman, who is called Mojtahid, can practice Ijtihad, meaning he can discover new rules of Islam according to some specific guidelines already in place or, to some extent, he may revise some existing rules. Fatwa, the idea which is released in certain subjects by a Mojtahid, is the result of practicing Ijtihad.

\footnotetext{
${ }^{281}$ Roohollah Khomeini, Sahifeh Noor, Vol.1, (Qom: Organization to protect and publish Imam Khomeini's works, 1990) at 34; also see: Sadegh Haghighat, "Realizing Time and Place in Ijtihad" in Ijtihad of Time and Place, Vol.2, (Qom: Organization to protect and publish Imam Khomeini's works, 1995) 37-88.

${ }^{282}$ Rohollh Khomeini, Islamic Jurisprudence(Tahrir-Al-Vasileh), translated into English by Laleh Bakhtiar, vol.1, (Tehran: Mabath Foundation Publishing, 1986) at7.
} 
To give an example of how Ijtihad works I can recall the idea of Velayate Faghih (Islamic Government in Shia Faith), which has no specific record in Islamic texts and can be justified only by using th epossibility of Ijtihad in Shia faith. ${ }^{283}$

New ideas in Shia jurisprudence focus on a new concept of continuing Ijtihad. According to this new approach, some Islamic concepts and rules must be revised frequently with respect to the necessities of the time and the place in which we live. A number of Islamic rules may not be suitable for all occasions or for all places, so it is necessary that these rules be interpreted and revised by Ijtihad. Execution and Qisas ${ }^{284}$ in Islam are among the debates these thinkers are interested in. ${ }^{285}$

A thinker in Islamic Shia faith, who suggested new ideas, especially after being released from prison, is Mohsen Kadivar. He challenged traditional Islam and believes in a new reading of the Islamic faith that is more acceptable in the modern world.

$\mathrm{He}$ insisted on the role of reason, and believes that examining the conflicts between Islamic law and human rights law in the light of reason will lead us to prefer human rights, as they are more defendable, reasonable and fair rules, as compared to traditional Islamic rules. According to him, a Mojtahed should differentiate between interim rules that have been established in Islam to solve problems at a specific time (such as 1400 years ago), or for specific people (like the Arab tribes), and permanent rules that are capable of being applied at all times, and to all people. The traditional Islamic view does not differentiate between the two, and treats all Islamic rules as permanent and immutable. Islamic traditionalists could not realize the reality of religion and its changing needs, and tended to ignore its intended goals. ${ }^{286}$

The new religious intellectualism has a solution to solve the traditional conflicts. In this view, each Islamic rule was established to meet a specific experience or to answer a particular question to provide Islamic societies with the benefits of clarity, growth, and understanding towards changing circumstances. If such an experience or question

\footnotetext{
${ }^{283}$ Emadodin Baghi, Contemporary Religious Ideas, (Tehran: Saraee Publishing, 2003) at 189.

${ }^{284}$ Supra note 246.

${ }^{285}$ Emadodin Baghi, Continuing Ijtihad, Shargh Daily, Sep. 25, 2003, at 1; online, Baghi website: http://www.emadbaghi.com/archives/cat religion.php

${ }^{286}$ Supra note 248 at $107 \& 111$.
} 
expired in another time, or there are some new questions that must be faced in this modern time, calling for an abandonment of such an outdated rule, then it must be changed accordingly. Mojtaheds are ones who must decide on these matters and are responsible for recognizing the necessity of change. ${ }^{287}$

Mostafa Mohaghegh Damad ${ }^{288}$ is one of the clerics who support a modern reading of Islam. With regard to human rights, his argument is more based on Islamic philosophy than Islamic Jurisprudence. He challenged the dominant question of the others: "are human rights accepted in Islam?",289 He believes it is better to ask a deeper question such as: "is the idea of human rights against religious thought or religious epistemology?" In other words, "is a religious man able to accept contemporary human rights principles, without feeling any kind of conflict?" ${ }^{290}$ He refuses the idea that religions prevent people from thinking, and that they make individuals believe in restricted ways that are determined by God or His representatives, as well as the idea that putting aside religious matters and considering humanism was the important key of progress in the West. In fact, he actually blamed Christianity and Judaism of being unable to let people think and use their sense of reason. ${ }^{291}$ Mohaghegh strongly argues that such an idea cannot be true in Islam, for Islam is based on thinking, rationalism, and wisdom as a source of faith. The Koran says: "Indeed we sent our messengers with signs and miracles as their proofs and revealed to them books of religion and also they were given the criterion for establishing justice among the people ... "292 He argues that according to this verse, the aim is to achieve justice and this justice will not be granted to people but it is people, themselves, who should make it possible by method of teachings and their own reason. The task of the prophet is only to improve their rational understanding of the realities in

\footnotetext{
${ }^{287}$ Supra note 248 at 114.

${ }^{288} \mathrm{He}$ is a cleric but at the same time he is a lawyer with a $\mathrm{PhD}$ degree. He serves as a law professor in the faculty of law, university of Beheshti in Tehran. He stopped working with the Iranian judiciary in 1990 as a very high ranking judge and head of the National Supervising Organization.

${ }^{289}$ Hussein Mehrpoor, Supra note 100 at 36.

${ }^{290}$ Mostafa Mohaghegh Damad, "Religious Epistimology and Human Rights' Thought" in International Human Rights and Negotiations Among Civilizations Seminar-Articles Collection" ed. Mofid University Administration, (Qom: Mofid University Publishing, 2001) 285-294 at 285.

${ }^{291}$ Ibid.

292 “Holy Koran", Surah Al-Hadid, Verse No. 25, (Tehran: Ershad Printing, 2001) at 1324.
} 
the world. People themselves should find their own way during their life, seeking justice based on their dynamic rational understanding. ${ }^{293}$

According to Mohaghegh, ${ }^{294}$ the Koran cannot be considered as a series of restrictive orders created to save people, without giving any justification. The important message of the Koran is to think and not to accept something against your reason. One of the Koran verses, tells the story of the inhabitants of hell, and points to the reason for being in hell. It says: "And they shall say: had we listened to their admonitions and had we used our reason we would not be among the inhabitants of Hell ${ }^{295}$. There are many sayings from the prophet Mohammad about using reason. In a Hadith he says that "all the best can be provided by reason and no faith for some people who has no reason" ${ }^{296}$, and in another he insists that "you can have both worlds by using your wisdom ..." 297

Mohaghegh, in another part of his discussion ${ }^{298}$, argues that the holy Koran supports the theory of natural rights in law by reasoning that the Koran states that people inherently are able to differentiate between what is bad and what is good in their life. It is a power inspired by God in the soul of man. This power is the most important difference between man and other creatures. The Koran says: "and (God) inspired both its evil and its good to it (man's soul)". ${ }^{299} \mathrm{He}$ also pointed to a famous principle in Islamic jurisprudence that is called Molazemah. According to this important basic principle "every judgment of the wisdom necessarily is a judgment of religion, and every judgment of religion necessarily is a judgment of wisdom". Islamic scientists mostly use this principle to interpret and to find new religious rules based on existing rules recognized by reason. If a religious notion conflicts with reason, it means that it needs to be interpreted in a way to solve the conflict because, according to this principle, such a concept could not be based on God's will. Mohaghegh, invoking this principle, believes that the message of this religion,

\footnotetext{
${ }^{293}$ Mostafa Mohaghegh Damad, Supra note 290 at 287.

${ }^{294}$ Mostafa Mohaghegh Damad, Supra note 290 at 288.

295 “Holy Koran", Surah Al-Mulk, Verse No. 10, (Tehran: Ershad Printing, 2001) at 1378.

296 "Tohaf-Al-Oghool" at 54, cited in: Mostafa Mohaghegh Damad, Supra note 290 at 288.

297 Arbali, "Kashf-Al-Ghamah" Vol.2, at 197, cited in: Supra note 290 at 288.

298 Mostafa Mohaghegh Damad, Supra note 290 at 289.

299 “Holy Koran", Surah Al-Shams, Verse No. 8, (Tehran: Ershad Printing, 2001) at 1494.
} 
applied to social life, is to live according to one's capacity for reason. ${ }^{300}$

He then summarized the discussion by explaining that first, human rights are based on the philosophical theory of natural law, and second, natural law is nothing but the outcome of direct human reasoning which leads people to understand what is bad and what is good. Human rights principles are the result of collective human reasoning and attempts of thinkers after centuries of bloodshed and war. Third, these findings and outcomes are not only acknowledged by the religion, but also, they are a very important part of the religion and override other religious rules considering the position of rationalism and wisdom in Islam. Fourth and finally, if we found any conflict between human rights and Islamic teachings we must interpret the religion in a way to fit human rights. If we do not, it means that we accept that religion may oppose reason, and this is against our realization of religion. $^{301}$

Briefly, the concept of human rights cannot go against religious epistemology, but further, it must be a part of religious thought. Practicing human rights principles is consistent with the religion as its goal is, ideally, to make justice possible in the world. ${ }^{302}$ There is another point of view to reconcile Islam and human rights. It is not an entirely new idea, but has recently been discussed more seriously, and has found more supporters among thinkers. This view invokes justice as an accepted criterion in the Shia faith. Justice is an objective concept, existing outside of and beyond religion, but every religion which concerns itself about justice should provide safeguards to protect all people's rights, regardless of their belief, race, and color. ${ }^{303}$ Providing justice in society means following God's orders. If we find any rule, which is not in accordance with justice, it cannot be admitted by God. ${ }^{304}$ Accepting human rights rules, as the outcome of human experience and the growth of humanity, is closer to justice and the true spirit of Islam. ${ }^{305}$

\footnotetext{
${ }^{300}$ Mostafa Mohaghegh Damad, Supra note 290 at 290.

301 Ibid.

302 Ibid at 292.

${ }^{303}$ Naser Ghorban Nia, "The Relation Between Justice and Human Rights" in International Human Rights and Negotiations Among Civilizations Seminar-Articles Collection" ed. Mofid University Administration, (Qom: Mofid University Publishing, 2001) 211-226 at 215.

${ }^{304}$ Morteza Motahari, Women's Rights in Islamic Legal System, $8^{\text {th }}$ ed. (Tehran: Sadra Press, 1980) at 46.

${ }^{305}$ Naser Ghorban Nia, supra note 303 at 223.
} 


\section{Chapter 6: Torture in Iran}

In this section I examine the history of torture in Iran in three different parts of history; first, before 1907, when there was no Constitution and modern legal system in Iran; second, torture in Iran between 1907 and 1979 when the Islamic Revolution occurred and third, torture in Iran after 1979.

\section{Section 6.1: Torture in Iran (Before 1907)}

In ancient Iran, under the Persian Empire, torture was vastly implemented. It was practiced both as an investigative instrument and as a method of punishment. Brutal punishments such as stoning, cutting a victim's body in half, and burning individuals alive were practiced against many accused people. ${ }^{306}$

The Code of Hammurabi ${ }^{307}(1795-1750 \mathrm{BC})$ the ruler who chiefly established the greatness of Babylon, is the first written code of human rights. It had a persuasive effect in limiting the use of torture. Although it contains a number of cruel punishments and ordeals, it counts crimes and punishments, and establishes a kind of evidence law which eliminates torture as a general technique for proving crimes. ${ }^{308}$

The religion of Zarathushtra, an Iranian prophet, played an important role in correcting the rules of acceptable behavior and promoting justice, consequently diminishing torture in ancient Iran. ${ }^{309}$ Moreover, Cyrus, the founder of the Iranian kingdom (560B.C.) and one of the most powerful kings of Iran, provided the first written text on human rights. This text demanded respect toward the dignity of human beings. His son Darius (521-485

\footnotetext{
${ }^{306}$ Tajzaman Danesh, Prisoners' Rights and Science of prisons, $3^{\text {rd }}$ ed. (Tehran, 1997) at 48; also see: Mahiar Khalili, History of Torture and Murderin Iran, $1^{\text {st }}$ ed . (Tehran, 1980) at 165.

${ }^{307}$ French archeologists found Hammurabi Code in two pieces in Shoosh, an Iranian ancient city, in 1901 and 1902. For more information see: Hammurabi Code far from our hands in Paris, Report by Cultural Department, Iranian National Heritage Organization, Miras News Agency, Feb. 21, 2004, online Miras Website: $w w w . c h n . i r /$ shownews.asp?no $=6948$; the code of Hammurabi is available online (Yale University website): http://www.yale.edu/lawweb/avalon/medieval/hammenu.htm

${ }^{308}$ Mohammad Ashouri, Criminal Justice, $1^{\text {st }}$ ed. (Tehran: Ganje Danesh Publishing, 1997) at 92.

${ }^{309}$ Abbas Manoochehri, Iranian Political System, $1^{\text {st }}$ ed., (Tehran: Cultural and International Studies Center Press, 2002) at 107; also see: Mohammad Hussein Aliabadi, History of Law, (Tehran: University of Tehran Press, 1957) at 18.
} 
B.C.) followed his way. According to a document found in Persepolis (near Shiraz, an ancient Iranian city), Darius condemned any oppression of the weak at the hands of the powerful. He called for justice and truth, rejecting any kind of injustice. In another document found in Naghshe Rostam (a historical place very close to Persepolis) he stated that: "Nobody can damage or harm the other, and if somebody does, we will punish him for sure". 310

Cyrus, respectful of women and children, allowed everyone in his territory the freedom to practice any religion. He was a kind man, considerate even towards his defeated enemies. However, torture did not cease in ancient Iran. ${ }^{311}$

Accepting Islam as a dominant religion in Iran after the Arab attack in the 7th century did not change the situation. Nor could Islamic teachings put an end to the practice of torture. Rather, the evidence shows that torture was still being used in Iran even during one of the most religious regimes of Safavids, and especially during the reign of Shah Abbess, an Islamic ruler in the 17 th century. ${ }^{312}$

During the 19th century, when Qajar Kings ruled the land (1800-1925) ${ }^{313}$, torture continued to be used to obtain confessions, regardless of new theories raised in punishment policy and developing legal systems. During this age, the Iranian system had not yet benefited from investigation methods as a means of providing further evidence to prove crimes. At that time, new methods of torture were invented and implemented. One of these methods was quite well known, as even its name was enough to irritate people. This terrible method was called Tange Qajari (Qajari Thight Band). Here, the torturer would tightly tie the top of the victim's body with a special band. This band was made of a particular material that, in water, would shrink in length. After tying the band around the victim's body, the torturer would then pour water on the band. As the band became shorter and shorter, it would press the body of the victim in a way that one could hear the

\footnotetext{
${ }^{310}$ Abolkalam Azad, Great Cyrus, Translated by Dr. Bastani Parizi to Persian (Tehran, 1990) at 15.

${ }^{311}$ Ahmad Matin Daftari, Human Rights and International Support, $1^{\text {st }}$ ed., (Tehran: Bahman Publishing, 1960) at 11; also see: Hassan Pirnia, Encient Iran, Vol.1, at 477.

${ }^{312}$ Morteza Ravandi, The History of Law and Justice In Iran, (Tehran: Cheshmeh Press, 1989) at 229\&230.

${ }^{313}$ For more information about Qajars see: Elton L. Daniel, Society and Culture in Qajar Iran, (Los Angeles: Mazda Publishing, 2002); also see: Hamzeh Sardadvar, The Mystery of Qajar, (Tehran: Elm Publishing Co., 2001).
} 
sound of his bones breaking. Such a pressure produces a terribly extreme pain throughout the whole body of the victim. ${ }^{314}$ Lord Cruzan (1892-1966) ${ }^{315}$, after describing the methods of torture that were used in Iran during the Qajars reign, acknowledged that the influence of new ideas in Europe, and attempts of Iranian reformists, put the rulers under pressure to accept some changes in their judicial system. ${ }^{316}$

The first serious step to eradicate torture, or at least to diminish it in Iran, was during the reign of Mohammad Shah Qajar, by the attempts of his prime minister Haji Mirza Aghasi in 1840. He ordered all the province governors in all of Iran to stop the physical abuse of accused people without a full investigation of each case. He stated that torture is against the belief system of Islam, and opposes justice and equity as well as the royal orders. $\mathrm{He}$ insisted that all accused must be treated as human beings and granted fair trial. ${ }^{317}$

Another step was taken in 1844 when a governmental declaration was sent to all provincial governors. Torture was one of the subjects discussed in this declaration. According to the declaration, torture, and extreme corporal punishments, which do not fit the crimes, must be stopped. All governors were advised not to torture anyone under any circumstances. Specifically, two reformist prime ministers, Mirza Taghi Khan (Amir Kabir) and Mirza Hosein Khan followed these steps ${ }^{318}$, but due to the weakness of the central governments, torture remained in use in some provinces. Another code of conduct signed by Amin Soltan, an Iranian prime minister in 1873, included an absolute ban on torture. $^{319}$

\section{Section 6.2. Torture in Iran (1907 - 1979)}

The reform campaign for Human Rights caused the Iranian first revolution, namely, the

${ }^{314}$ S. A. Mousavi, Torture in the Iranian Law, UN and Council of Europe Criminal Policy, (Tehran: Khate Sevom Publishing, 2003) at 25.

${ }^{315}$ George Cruzan, Persia and the Persian Question, vol. 1 (Tehran: Elmi va Farhangi Publishing Co., 1983 ) at 456.

${ }^{316}$ For more information about the influence of emerging ideas in Iran see: Karim Mojtahedi, New Philosophical Ideas in West and Iranian People, (Tehran: Temporary History of Iran Institution Press, 2000).

${ }^{317}$ Fereidoun Adamiat, Amir Kabir and Iran, $8^{\text {th }}$ ed., (Tehran: Kharazmi Publishing, 1999) at 313.

${ }^{318} \mathrm{He}$ was one of the reformist prime ministers who was killed by the king. For more information about him see: Naser Enghetaa, Amir Kabir: A Light in Darkness, $2^{\text {nd }}$ ed. (Los Angeles: Ketab Corp., 2002).

${ }^{319}$ Fereidoun Adamiat, supra note 317 at $314-315$. 
Constitutional Revolution (Mashrouteh). In the wake of the relentless efforts of freedom fighters, Mozafar o-Din Shah of the Quajar dynasty was forced to issue the decree for the Constitution and the creation of an elected parliament (the Majlis) on August 5, 1906. The royal power were limited and a parliamentary system established. The most important task undertaken by the first Majlis was drafting and ratification of the Constitution on December 30th, 1906. It also set out the internal procedures. On October 17th, 1907 it drafted and ratified the Constitutional amendments. ${ }^{320}$

Although the Constitution did not address the question of torture directly, in article 9, it pointed to the dignity of nationals and the fact that life, property, home, honor and dignity of all must be respected and supported by law. Moreover, article 12 stated that all sentencing and administering of punishments must strictly adhere to the law. ${ }^{321}$ On the other hand, the first Iranian Constitution and its amendments were defining human rights and banning torture indirectly. ${ }^{322}$

In the early twentieth century, in Iran, due to the weakness of the Qajar king (Ahmad Shah), Reza Pahlavi ${ }^{323}$ overthrew the king and came to power as the new king in 1923 , supported by Britain, and claimed to establish a modern state while putting an end to the disorder caused by the Qajar kings. ${ }^{324}$

He started the process of alleged modernization of Iran. He removed the clergies' power over the judicial system and established a modern European judicial system. During his reign (1923-1941), torture was practiced widely. ${ }^{325}$ However, many laws

\footnotetext{
${ }^{320}$ For information about the Mashrooteh Revolution see: Mohammad Reza Afshari, "The Historians of the Constitutional Movement and the Making of the Iranian Populist Tradition", International Journal of Middle East Studies, 1993, 25(3): 477-494; also see: Edward J. Brown, History of Mashrooteh Revolution, Translated by Mehri Ghazvini, (Tehran: Nashre Kavir, 2001).

${ }^{321}$ S. A. Mousavi, supra note 314 at 27.

${ }^{322}$ For more information about the first constitution see: Ghasem Ghasemzadeh, Constitutional Law, ed. 1, (Tehran: Tehran University Press, 1955) at 360-367.

${ }^{323}$ For more information about him see: Farhad Rostami, Pahlavies: Reza Sahah, Vol.1, (Tehran: Iranian History studies Institution Press, 1999) also see: Mohammad Dehnavi, "Pages from History" in Contemporary Iranian History, ed. Iranian History Institute, Vol.1, at 133 .

${ }^{324}$ See: Sandra Mackey, supra note 7 at 157; also see: Hussein Makki, "Coup of 1920, Dr. Mossadegh and Oil" an interview made by Iranian History studies Institution, March 1996, online: http://www.iichs.org/archived/Tarikhshafahi7.htm;

${ }^{325}$ For details see: J. E. Knorzer, Ali Dashti's Prison Days Life Under Reza Shah, (Los Angeles: Mazda Press, 1994); also see: Ziaoddin Sadrolashrafi, A memory about Kasravi, Derang Bi-monthly, third year, No.11, March 2003, at 4. online: http://www.kasravi.infol
} 
were approved by parliament, which shaped a real legal system in Iran. As we will discuss later, torture was banned legally and criminalized for the first time in the Public Punishment Code $^{326}$ of 1926. But, the existence of such a clear text did not prevent officials from practicing torture, as the king continued to depend on torture to control opposition groups and journalists. According to the memoirs of prisoners, especially those of political activists and journalists, incredibly inhuman and degrading treatment was used during their interrogations in order to make them confess. ${ }^{327}$ Mohammad Taghi Bahar (1887-1951), an Iranian poet, journalist, and one of the most famous political prisoners, described the situation in prisons and custodies in some of his poems stating that detainees were ready to confess what they did commit, as well as what they had never committed after being tortured severely during the interrogation, or while in prison. According to him, torture has been used vastly in Reza Shah's tyranny. ${ }^{328}$

After the Second World War, the idea that torture in the modern world was no longer morally acceptable, and should not be justified by national and international law, began to spread in many countries. War criminals were prosecuted in the Nuremberg and Tokyo trials, and the world moved toward preventing such events from ever happening again in the future. ${ }^{329}$

Reza Shah was sent to exile in 1941, and his son Mohammad Reza Shah, came to power to be the last Shah of Iran until 1979. ${ }^{330}$ Some torturers under Reza Shah have been put to trial after he left power. Among them was Pezeshk Ahmadi, who was working as a doctor in the prisons for years, though his main mandate was to torture or to kill the prisoners under orders from the Shah or the head of police. His name was often associated with death and pain. ${ }^{331}$

The young Shah established an intelligence organization called SAVAK. This

\footnotetext{
${ }^{326}$ Public Punishment Code, Official Gazzette, Jan. 26, 1926, Vol. 1, Series 5 at 69.

${ }^{327}$ Mahmood Hakimi, Stories of Reza Shah Age, $2^{\text {nd }}$ ed. (Tehran: Ghalam Publishing, 1992) at 261.

${ }^{328}$ Chehrzad Bahar, Collection of Bahar's Poems, Vol.2 (Tehran: Toos Press Co., 2001) at 14.

${ }^{329}$ Ibid at 31 .

${ }^{330}$ For more information on how the power transferred to him see: Ali Ansari, A History of Modern Iran Since 1921 The Pahlavis and After, $1^{\text {st }}$ ed. (London: Longman, 2003).

${ }^{331}$ Kasravi's defence in Ahmadi's Court, Parcham Daily, No.164, Wednesday, Aug. 16, 1942.
} 
organization was responsible for torturing and killing a number of political activists for many years. ${ }^{332}$ At the same time, Iran was contributing to the international community attempts to promote human rights and became a party to the Covenant on Political and Civil Rights ${ }^{333}$.

In 1968, the year that were designated as the International Year for Human Rights, the International Conference on Human Rights was held in Tehran to mark the twentieth anniversary of the Universal Declaration of Human Rights, and to enhance national and international human rights efforts and initiatives. This Conference resulted in the Proclamation of Tehran ${ }^{334}$, which formulated a program for the future, addressing the problems of colonialism, racial discrimination, illiteracy and the protection of the family. I examine the laws and regulations (1907-1979) related to the question of torture in the following sub-sections.

\section{Sub-section 6.2.1: The first Iranian Constitution}

As I mentioned above, the first Iranian Constitution was approved right after the gracious victory of the Mashrooteh Revolution (1906) ${ }^{335}$. Although the totalitarian Qajar kings were never willing to share their absolute power with others, Iranians were affected by new ideas, and were seeking justice and more participation in their government. They strongly believed that they deserved to have a Parliament and judiciary as well as a written Constitution that would control the king's power. ${ }^{336}$

There is no doubt that this revolution's achievements were and still are a good basis for reviving people's rights and promoting human rights in Iran.

The Constitution, including 51 articles, came into force in 1907, and its first amendment of 101 articles was approved in 1907. As I mentioned above, this Constitution did not

\footnotetext{
${ }^{332}$ Ehsan Naraghi, "The Structure of SAVAK and Army during the Shah's Reign" an interview made by Morteza Rasouli for Iranian History studies Institution, March 1996, online: http://www.iichs.org/archived/tarikh/113.htm .

${ }^{333}$ Supra note 36.

${ }^{334}$ Proclamation of Teheran, Final Act of the International Conference on Human Rights, Teheran, 22 April to 13 May 1968, U.N. Doc. A/CONF. 32/41 at 3 (1968), online (UNHCHR website): http://www.unhchr.ch/html/menu3/b/b tehern.htm

${ }^{335}$ Sandra Mackey, supra note 7 at 148.

${ }^{336}$ Ibid at 149.
} 
address the concept of torture directly, but there are several articles about human dignity and respecting life, property, and the home and the honor of the people.

Sub-section 6.2.2: Parliamentary laws

The first law in Iranian legal history that clearly banned and criminalized torture was the Public Punishment Code $^{337}$ of 1926 . Section 131 of the mentioned act stipulates that:

"public officials, judicial or non-judicial, who torture or order to torture a detainee or a prisoner in order to obtain confession or other information shall be sentenced to jail for 3 to 6 years. If the victim dies as a result of torture it is considered as a murder. The torturer shall be sentenced as a murderer and superior officials who ordered him to torture shall be sentenced as who ordered to murder"

Moreover, Section 194 of the mentioned Code which is about the crime of arbitrary detention stipulates that:

"In crime of arbitrary detention, if the offender has treated the victim to death or tortured him, he shall be sentenced to jail for the period of 3 to 10 years"

Section 136 of the same Code banned treating people who are not detainees or prisoners inhumanely as it says that:

"Every public official who treated an individual inhumanely or abused him physically or orders one to do so, while he is on duty, shall be sentenced to the maximum of the punishment of that crime."

It is clear that this legal text banned torture strongly, but did not address the subject of non-physical torture. Moreover, it did not offer any specific definition of torture or physical abuse.

The presence of a lawyer accompanying the detainee can be a good safeguard to prevent

${ }^{337}$ Public Punishment Code, supra note 326. 
interrogators from torturing the detainees. The first modern Criminal Procedure Code 338 in 1930 recognized the right to legal assistance but did not clearly state that a lawyer is allowed to be present in an interrogation session.

This issue was to be made clearer in the Code of Revising a Part of Criminal Procedure $^{339}$. This code stated that every accused was permitted to be accompanied by an attorney during the investigation process. The attorney accompanying the accused could not interfere in the process of investigation but, at the end of the investigation, he could make note of everything that may be useful for recovering the truth. Moreover, he could protest every illegal action by the agents. All of his commentaries must be recorded.

The right to silence is recognized for accused people in section 125 of the same code, stating that prosecutors cannot oblige or make the accused confess, and if the accused refuses to answer the questions, the prosecutors must mention this fact in the report of the interrogation session.

There was no other safeguard in place to prevent a victim from being tortured, such as access to regular medical services, or supervision of prisons and other places of detention, in these legal texts.

In the Iranian legal system, all international conventions and treaties to which Iran is a party are part of the domestic Iranian law. Section 9 of the Iranian Civil $\operatorname{Code}^{340}$ of 1928 states : "the content of international agreements to which Iran is a party is binding and must be considered as law", so that all international conventions and legal texts against torture, signed and ratified by Iran, are also considered a part of Iranian law.

In addition, the Iranian government needs parliament approval to be a signatory to the international agreements according to the Mashrooteh Constitution, which remained in the Islamic Constitution (Article 77), so the content of the agreements, would be approved by the parliament. As a result, there is no doubt that the content of an international agreement is a part of domestic law. I address some of these laws below. A particular legal text related to the question of torture is the Code of Permission for Iran

${ }^{338}$ Criminal Procedure Code, National Parliament, July 22, 1930, Official Gazette No. 496, Duration 7, Vol. 1, at 152.

${ }^{339}$ Code of Revising A Part of Criminal Procedure, National Parliament, Feb. 20, 1957, Official Gazette No. 3562, Duration 19, Vol. 4, at 2200.

${ }^{340}$ Civil Code, Official Gazette, April. 10, 1935, Vol. 1, Series 10 at 4. 
joining the Geneva Conventions ${ }^{341}$ of 1955 . Sections 12,13 and 50 of this code contain an absolute ban on the use of torture, degrading and inhuman treatment, as well as on biological tests in armed conflicts.

Section 384 of the Military Judicial Procedure and Punishment Code ${ }^{342}$ criminalized torture and maltreatment of the injured or sick soldiers during the war. The punishment of one who commits such a crime is jail term of 2 to 10 years, and in some cases, capital punishment can even be considered.

According to section seven of the "Code of Permission for Iran joining the Covenant on Civil and Political Rights" ${ }^{343}$ approved in 1975, Iran became a party to the covenant. ${ }^{344}$ The covenant in Article 7 states, "No one shall be subjected to torture or to cruel, inhuman or degrading treatment or punishment ..."

It is necessary to mention that there are no corporal punishments prescribed in Iranian law before the Islamic Revolution of 1979.

\section{Sub-section 6.2.3: Bylaws}

There are some regulations stipulated in bylaws about how to treat prisoners. The most important bylaw is the Prisons Regulations prepared by Swedish missioners and approved by the Iranian government in 1919. In this Code of Conduct, the physical torture and enchainment of prisoners were strongly banned. ${ }^{345}$

\section{Section 6.3: Torture in Iran (After 1979)}

In 1979, after the Islamic Revolution, the Islamic Republic regime governed by clergies

\footnotetext{
${ }^{341}$ Code of Permission for Joining Iran to the Geneva Conventions, Official Gazette, Dec. 20, 1955, Vol. 1, Series 18 , at589.

${ }^{342}$ Military Judicial Procedure and Punishment Code, Official Gazette, Dec. 24, 1939, Vol.1, Series 12 at 70.

${ }^{343}$ Code of Permission for Joining Iran to the Covenant on Civil and Political Rights, Official Gazette, May 7, 1975, Vol. 16, Series 23, at 3678.

${ }^{344}$ Shirin Ebadi, History and Human rights Documents, (Tehran: Roshangaran Publishing, 1994) at 66.

${ }^{345}$ Mohammad Hashemi, "Protecting Citizens in Islamic System, Iranian Law and International Law" in International Human Rights and Negotiations Among Civilizations Seminar-Articles Collection" ed. Mofid University Administration, (Qom: Mofid University Publishing, 2001)363-380 at 375; also see: Abdolamir Manshdavi, Prison over the History, $1^{\text {st }}$ ed., (Ahvaz, Iran: Khoozestan Province Prisons Affairs Office, 1999) at34.
} 
came into force in Iran. The practice of torture, especially during the interrogation process, continued even after the Islamic Revolution. This portion of the Iranian history will be discussed in detail in several sections to follow.

The Islamic Republic's life can be divided into three specific parts: first, from 1979 to 1981, when the Islamic Republic was established. ${ }^{346}$ The commanders of the Shah's regime were assumed guilty and, without fair trial, were executed shortly after the victory of Islamists. No torture has been reported in that time. ${ }^{347}$

Second, from 1981 to 1997 , right after the clergies achieved total power they put many political activists who were their partners during the revolution in jail. According to the information released predominately after 1997, during this time, torture had been widely in use. A large number of victims were executed in 1988 according to an order issued by Ayatollah Khomeini, but much of the evidence has been buried. ${ }^{348}$ Some international reports provided by the UN and some NGOs show only a very small part of the reality, but recently a number of the survivors have written their memoirs published in books ${ }^{349}$, or in open letters ${ }^{350}$.

Third, from 1997 until now, the presence of reformists in power, or at least holding a small part of the political power, exposed many truths. The hardliners who control the judiciary could no longer do whatever they wanted in places of detention and imprisonment for fear of publication by journalists. Victims of torture are often brave enough to tell the realities in torture chambers after being released. ${ }^{351}$

Members of parliament started to criticize the use of torture ${ }^{352}$, and the Committee to

\footnotetext{
${ }^{346}$ For more information about this period see: Barzin, Saeed. "Constitutionalism and Democracy in the Religious Ideology of Mehdi Bazargan", British Journal of Middle Eastern Studies, 1994 21(1): 85-101 ${ }^{347}$ See: John Simpson, Life under Khomeini's Regime inside Iran, (New York: St. Martin's Press, 1988) at 49.

${ }^{348}$ See: Robin Wright, In the Name of God: The Khomeini Decade, (New York: Simon \& Schuster, 1989) at 196; also see: Amnesty International, Iran Political Executions, AI INDEX: MDE 13/29/88 DISTR: SC/CO/GR, December 1988.

${ }^{349}$ For example see: Habibollah Davaran \& Farhad Behbahani, Two Memoirs of prison: In Haji Party \& the Story of a Confession, (Tehran: Omide Farda Publications, 2001); this book banned by the Iranian judiciary right after publication and it is very hard to find a copy in Iran.

${ }^{350}$ Dr. Maleki's letter, infra note 449.

${ }^{351}$ For example see: supra note 349.

${ }^{352}$ See below: 8.1 .
} 
Implement Article 90 of the Constitution in Parliament ${ }^{353}$ heard complaints about torture and came to investigate several cases. ${ }^{354}$

Journalists released more and more cases, and the internet allowed them to publish what they could not publish in their newspapers. In the case of Zahra Kazemi ${ }^{355}$, student groups, journalists, members of parliament and other politicians, and human rights activists, as well as international political pressure, put hardliners in a very bad situation, and all their attempts to hide the reality failed.

I examine some of the reports and facts for the two latter periods.

Sub-section 6.3.1: Situation from 1981 to 1997

Galindo Pohl was the first UN special representative for Iran, appointed by the Commission on Human Rights. He provided the international community with several reports on the situation of human rights in Iran. ${ }^{356}$ Due to the limitations on information available, some believe he could not reflect the whole reality of violations of human rights in his reports. ${ }^{357}$

The question of torture is one of his main concerns in his reports. He reported that torture and other cruel, inhuman or degrading treatment is being used vastly during the interrogation of detainees to extract confessions about their activities and political association before their arrest. ${ }^{358}$ The prolonged incommunicado detention facilitates the

${ }^{353}$ One of the permanent working committees of the Iranian Parliament is the Committee to Implement Article 90 of the Constitution. Article 90 of the Iranian Constitution stipulates: "Whoever has a complaint concerning the work of the Assembly or the executive power, or the judicial power can forward his complaint in writing to the Assembly. The Assembly must investigate his complaint and give a satisfactory reply. In cases where the complaint relates to the executive or the judiciary, the Assembly must demand proper investigation in the matter and an adequate explanation from them, and announce the results within a reasonable time. In cases where the subject of the complaint is of public interest, the reply must be made public."

${ }^{354}$ For example the committee investigated about the Case of Zahra Kazemi and released a report on this case which is one of the most reliable documents. See below part 6.3.4.2.

${ }^{355}$ See below part 6.3.4.2

${ }^{356}$ For example see UN Documents: E/CN.4/1987/23, E/CN.4/1989/26, E/CN.4/1990/24, E/CN.4/1991/35, E/CN.4/1992/34, E/CN.4/1993/41, E/CN.4/1993/41, A/49/514/Add.1, A/49/514/Add.2, E/CN.4/1994/50, $\mathrm{E} / \mathrm{CN} .4 / 1994 / 50$ and $\mathrm{E} / \mathrm{CN} .4 / 1995 / 55$

${ }^{357}$ Reza Afshari, supra note 48, at 52.

${ }^{358}$ Reynaldo Galindo Pohl, Report On the Human Rights Situation in the Islamic Republic of Iran, UN Doc. E/CN.4/1987/23, at.13. 
torture of detainees especially in political cases. ${ }^{359}$

He visited some prisoners who managed to escape from Iran, and received some new testimonies about torture. ${ }^{360}$

He reported different methods which are in use in Iranian prisons such as:

- Setting rape of prisoners (especially political prisoners) by sadistic inmates ${ }^{361}$

- Keeping prisoners in a very cold cell for many hours ${ }^{362}$

- Keeping in solitary confinement for months ${ }^{363}$

- Lashing, beating severely and other forms of physical abuse (most frequently, severe and repeated beating with cables or other instruments like rifle butts on the back and the soles of the feet) ${ }^{364}$

- Stuffing a cloth into the victim's mouth to stop him or her from screaming while being beaten and making it hard to breathe properly. ${ }^{365}$

- Insulting prisoners ${ }^{366}$

- $\quad$ Sleep deprivation ${ }^{367}$

- Keep the prisoners blind folded for a long time ${ }^{368}$

- Suspension for long periods in contorted positions ${ }^{369}$

- Burning with cigarettes ${ }^{370}$

- Keeping prisoners in uncertainty of time and place ${ }^{371}$

\footnotetext{
${ }^{359}$ Reynaldo Galindo Pohl, Report On the Human Rights Situation in the Islamic Republic of Iran, Commission on Human Rights, Sess. $50^{\text {th }}$, 2 February 1994, UN DOC. E/CN.4/1994/50, P.87.

${ }^{360}$ Situation of human rights in the Islamic Republic of Iran, , Sess. $42^{\text {nd }}$, UNGA Res. A/42/648, at 7.

${ }^{361}$ Situation of human rights in the Islamic Republic of Iran, , Sess. $43^{\text {rd }}$, UNGA Res. A/43/705, at 9.

${ }^{362}$ Reynaldo Galindo Pohl, Report On the Human Rights Situation in the Islamic Republic of Iran, UN DOC. E/CN.4/1990/24, P.32.

${ }^{363}$ Reynaldo Galindo Pohl, Report On the Human Rights Situation in the Islamic Republic of Iran, UN Doc. E/CN.4/1991/35 Para. 74 -75.

${ }^{364}$ Supra note 359, P.83.

${ }^{365}$ Reynaldo Galindo Pohl, Final Report on the situation of human rights in the Islamic Republic of Iran pursuant to Commission resolution 1992/67 of 4 March 1992, UN Doc. E/CN.4/1993/41, Commission of Human Rights, Sess. 49 ${ }^{\text {th }}, 28$ January 1993, Para 104.

${ }^{366}$ Supra note 362, P.32.

${ }^{367}$ Supra note 363, Para. 48.

${ }^{368}$ Supra note 365, Para 105.

${ }^{369} \mathrm{Ibid}$, Para 104; also see: supra note 359, P.83.

${ }^{370}$ Supra note 365, Para 104: also see: supra note 359, P.83.

${ }^{371}$ Supra note 365, Para 105.
} 
- $\quad$ Being kicked or punched ${ }^{372}$

- Being made to stand without moving for hours or days at a time $\mathrm{e}^{373}$

- Cancellation of family visits ${ }^{374}$

- Food deprivation ${ }^{375}$

It has been reported that torture and other forms of physical or psychological ill-treatment were applied not only to obtain information but also to extract statements; sometimes the torture was recorded on film. ${ }^{376}$

During a visit to Evin prison ${ }^{377}$, Galindo Pohl met with some important political prisoners such as Nureddin Kianuri, the head of a leftist pro-soviet party in Iran, and Mohammad Tavassoli, the first mayor of Tehran after the Islamic Revolution. Both of them told Pohl that they had been severely tortured. ${ }^{378}$

Galindo Pohl, in his report ${ }^{379}$ of 1991 , pointed to 13 Jewish people who were subjected to torture after being arrested in the city of Shiraz. They were forced to confess on TV, to being spies for foreign states. They were also held in solitary confinement for months in Evin prison in Tehran. In the same report ${ }^{380}$, Pohl acknowledged that he received many other reports on the question of torture in Iranian custodies.

The question of capital punishment is among serious concerns of Galindo Pohl. Mass execution of prisoners in summer 1988 was reported by him in $1989 .{ }^{381}$ A large number of political prisoners were executed based on an order of Ayatollah Khomeini without any fair trial. ${ }^{382}$ As Ayatollah Montazeri ${ }^{383}$ mentioned in his memoirs, during that

\footnotetext{
${ }^{372}$ Supra note 365 , Para 106: also see: supra note 359, P 88.

${ }^{373}$ Supra note 365 , Para 106.

${ }^{374}$ Ibid.

${ }^{375}$ Ibid.

${ }^{376}$ Ibid

${ }^{377}$ It is a horrible prison in the north of Tehran. For more information see: The Large Gate of Evin, APT Journal, Vol. 0, 1995, 4-5.

${ }^{378}$ Supra note 362 , para.32.

379 Supra note 362.

${ }^{380}$ Ibid Para $74-75$.

${ }^{381}$ Supra note 358, Para 25-36.

${ }^{382}$ Ibid at.22.

${ }^{383}$ Ayatollah Montazeri was in a home-detention for more than five years without being trialed or sentenced. He was subjected to many illegal pressures for example see: supra note 359, P 89.
} 
incident, all virgin female victims were raped by the guards in order to be capable of being executed according to their understanding of Islamic jurisprudence. ${ }^{384}$

Corporal punishments are also frequently reported in Galindo Pohl's reports. Based on his report of 1993, he was informed of flogging in the public ${ }^{385}$ inflicted by the Islamic Revolutionary Courts on charges of illegitimate relationships, harassment, and drinking alcohol, and of amputation of fingers on charges of stealing in the presence of judges, employees and people ${ }^{386}$. The same incidents were reported in his 1994 and 1995 reports. $^{387}$

The Iranian government denies allegations of practicing torture in Iranian prisons mentioned in Galindo Pohl's reports. ${ }^{388}$

On 2 August 1995, following the resignation of Mr. Galindo Pohl, the Chairman of the Commission on Human Rights appointed Professor Maurice Danby Copithorne (Canada) as Special Representative of the Commission on Human Rights on the situation of human rights in the Islamic Republic of Iran.

Mr. Copithorne, in his 1996 report $^{389}$ delivered following his visit to Iran, criticizes the existence of corporal punishments in Iranian penal law as serious breaches of human

\footnotetext{
${ }^{384}$ Ayatollah Hussein Ali Montazeri, supra note 3, Chapter 9, at 373; online (Montazeri website): http://www.montazeri.ws/Farsi/Khaterat/html/0011.htm\#0373

${ }^{385}$ Supra note 367 , Paras $119 \& 122$.

${ }^{386} \mathrm{Ibid}$, Para 12.

${ }^{387}$ Supra note 359, P.84 \&90-91 and Reynaldo Galindo Pohl, Report On the Human Rights Situation in the Islamic Republic of Iran, Commission on Human Rights, Sess. $51^{\text {st }}, 16$ Jan. 1995, UN DOC. E/CN.4/1995/55, P.31 \& 92.

${ }^{388}$ Letter dated 8 May 1995, Letter dated 23 May 1995 and Letter dated 10 June 1995 from the Permanent Representative of the Islamic Republic of Iran to the United Nations Office at Geneva addressed to the Special Representative of the Commission on Human Rights on the situation of human rights in the Islamic Republic of Iran, see: Maurice Copithorne, Interim report on the situation of human rights in the Islamic Republic of Iran, submitted by the Special Representative of the Commission on Human, UNGA , $50^{\text {th }}$ sess., 20 October 1995, A/50/661, Annexes I, II \& III, online (UNHCHR website):

http://www.unhchr.ch/Huridocda/Huridoca.nsf/TestFrame/72cd076de00fld16802567210059f378?Opendoc ument

${ }^{389}$ Maurice Copithorne, Report on the situation of human rights in the Islamic Republic of Iran, prepared by the Special Representative of the Commission on Human Rights, pursuant to Commission resolution 1995/68 of 8 March 1995 and Economic and Social Council decision 1995/279 of 25 July 1995, 52 ${ }^{\text {nd }}$ sess., UN Doc. E/CN.4/1996/59, 21 March 1996, online (UNHCHR website):

http://www.unhchr.ch/Huridocda/Huridoca.nsf/TestFrame/7ebfad320flab68e802566da00532ab5?Opendoc $\underline{\text { ument }}$
} 
rights. He found that punishments mentioned in Iranian penal law ${ }^{390}$ such as amputation, stoning and execution as severe punishments constitute torture. In his meeting with Ayatollah Yazdi, the head of the judiciary, Mr Copitorne expressed his concerns, but Yazdi replied that many conditions have to be met before these kind of punishments carried out and that is why they were rarely applied. ${ }^{391}$ According to the same report he had met some Iranian political prisoners, among them Abbas Amir Entezam, former Deputy Prime Minister of the Provisional Government of Iran in 1979, which complained of reprisals for having met with the former Special Representative in December 1991. He complained of being tortured to the point of having lost the hearing in his left ear. ${ }^{392}$

Lashing was the primary method of torture used in Iran's prisons before the Islamic revolution. ${ }^{393}$ After the revolution, it began to be used again under an Islamic justification. The revolutionary torturers consider beating the prisoners as Islamic Punishment of Tazir. ${ }^{394}$ It is only an abuse of Islamic concepts. It is true that applying Tazir may constitute torture with regard to the international definition of torture, but it is a punishment after trial and conviction by a competent judge. Then, lashing and beating prisoners or detainees before trial in order to obtain information or confession is not Tazir at all. It falls under the definition of torture in Islamic law.

The first Special Rapporteur on torture, Mr. Peter Koojimans, paid attention to the methods which are being used in Iranian prisons in his report of $1992 .{ }^{395} \mathrm{He}$ pointed to burning by cigarettes, severe beating with cables etc. ${ }^{396}$

\footnotetext{
${ }^{390}$ See below: sub-section 6.3.6.

${ }^{391}$ Supra note 389, Para 42.

${ }^{392}$ Ibid Para 105; also see: Nigel S. Rodley, Report of the Special Rapporteur submitted pursuant to Commission on Human Rights Resolution 2000/43, Commission on Human Rights, $57^{\text {th }}$ Sess., UNDoc. E/CN.4/2001/66, 25 Jan. 2001, para 622; also see: Nigel S. Rodley, Report of the Special Rapporteur submitted pursuant to Commission on Human Rights Resolution 2001/62, Commission on Human Rights, $58^{\text {th }}$ Sess., UNDoc. E/CN.4/2002/76/Add.1, 14 March. 2002, para 748.

${ }^{393}$ See: supra note 3.

${ }^{394}$ Reza Afshari, supra note 48, at 47.

${ }^{395}$ Peter Koojimans, Report of the Special Rapporteur submitted pursuant to Commission on Human Rights Resolution 1992/32, Commission on Human Rights, $49^{\text {th }}$ Sess., UNDoc. E/CN.4/1993/26, 15 Dec.1992, 276 $-282$.

${ }^{396}$ Ibid Para 277.
} 
Mr. Nigel Rodley, the second special Rapporteur on torture, in his 1995 report $^{397}$, pointed out the question of practicing amputation and flogging as a means of punishment in Iran. ${ }^{398} \mathrm{He}$ also noted that Feizollah Mekhoubad, an Iranian Jew who was charged with espionage for Israel, was kept in solitary confinement for a long time while he was chained. He was brutally flogged on his back, limbs and face. After his execution, his family observed that his teeth, his eyes and two fingers were missing. ${ }^{399}$

He advised the Iranian government that he had received information about keeping political detainees incommunicado for a very long time denying them access to lawyers. ${ }^{400}$ The following methods of torture have been added to the previous list made by Galindo Pohl ${ }^{401}$ in Mr. Rodley's report ${ }^{402}$ :

- Prolonged enforced standing on one leg;

- Detention in extremely confined space;

- Suspension by the hands, ankles or other body parts, sometimes from a rotating ceiling fan;

- Electric shocks

- Shackling the arms in painful positions

Reza Afshari speaks out about newly invented methods of torture used by Iranian torturers after the Islamic revolution, such as Qapan (steelyard) and Dastgah (instrument). He describes Qapan as follows:

"... one arm would be extended over the shoulder to reach the other arm, stretched from the side toward the back. The guards would pull the hands to meet behind the back to be handcuffed. Soon the pain

\footnotetext{
${ }^{397}$ Nigel S. Rodley, Report of the Special Rapporteur submitted pursuant to Commission on Human Rights Resolution 1995/35, Commission on Human Rights, $50^{\text {th }}$ Sess., UNDoc. E/CN.4/1995/34, 12 Jan. 1995, 402-411.

${ }^{400}$ Nigel S. Rodley, Report of the Special Rapporteur submitted pursuant to Commission on Human Rights Resolution 1995/35, Commission on Human Rights, $52^{\text {nd }}$ Sess., UNDoc. E/CN.4/1996/35, 9 Jan. 1996, 8081 Para 80.

${ }^{401}$ See above at 83.

${ }^{402}$ Nigel S. Rodley, Report of the Special Rapporteur submitted pursuant to Commission on Human Rights Resolution 1995/35, Commission on Human Rights, 53 ${ }^{\text {rd }}$ Sess., UNDoc. E/CN.4/1997/7/Add.1, 20 Dec. 1996, Para 242.
} 
would extend from the arms to the entire body..." 403

He describes Dastgah as a new method invented in the Quezel Hesar Prison by an infamous warden and torturer of the prison, whose name was Haji Rahmani. Afshari described Dastgah as:

"on the edge of a room close to the walls, guards erected wooden partitions that separated each prisoner from the next in such a confined space that they were unable to move. They kept the prisoners in that position day and night, only allowing them to go to the lavatory once a day. Some prisoners referred to the Dastgah as (Ghabr) a burial vault", 404

Some prisoners had been kept sitting like statues in the Dastgah for up to ten months. ${ }^{405}$ These details never appeared in international reports, and none of them can be justified by any cultural rationale or Islamic teachings. ${ }^{406}$

Amnesty International's reports, during the 1980s, succeeded in reflecting a more complete story of Iran's prisons. ${ }^{407}$

Sub-section 6.3.2: Situation from 1997 to 2004

Maurice Copithorne in his report of February 1997 complained about the complex nature of Iranian society and in particular, a form of governance that is far from transparent and makes his mandate so difficult to be carried out from outside of Iran. ${ }^{408}$

Actually, he was right. The complexity of Iranians proved when they unexpectedly voted

\footnotetext{
${ }^{403}$ Reza Afshari, supra note 48 , at 48.

${ }^{404}$ Ibid.

${ }^{405}$ Ibid. at 49.

${ }^{406}$ Ibid.

${ }^{407}$ Amnesty International Reports are more detailed for example see: Amnesty International, supra note 348.

${ }^{408}$ Maurice Copithorne, Report on the situation of human rights in the Islamic Republic of Iran, prepared by the Special Representative of the Commission on Human Rights, pursuant to Commission resolution 1995/68 of 8 March 1995 and Economic and Social Council decision 1995/279 of 25 July 1995, 53 ${ }^{\text {rd }}$ sess., UN Doc. E/CN.4/1997/63, 11 Feb. 1997, Para 8, online (UNHCHR website):

http://www.unhchr.ch/Huridocda/Huridoca.nsf/TestFrame/4b39ee28e64567e7802566cc003e7c4c?Opendoc ument
} 
Khatami, a reformist cleric, as president in May 1997 to show their refusal of the hardliners. It could be a beginning for serious changes in the human rights situation in Iran, bearing in mind that Khatami's slogan was “Iran for All Iranians". It was explicitly against the fundamentalist ruling idea to divide people into man and woman, insiders (pro-Velayate Faghih or Hezbollahi) and outsiders (against Velayate Faghih); etc. More than 20 million of hopeful Iranian voters voted for Khatami against a hard-liner candidate who was backed up strongly by the supreme leader, Ali Khamenei, and could gain only 4 million of votes. ${ }^{409}$ To show how hopeful was such a victory, I recall the comment of Dr Abdolkarim Soroush, a very well known Iranian scholar who said "The election was a referendum on liberty, justice, everything!"410 Khatami's victory was repeated with almost the same result in the eighth presidential election in 2001.

Reformists also won the parliamentary election in Feb. 2000. It was a good opportunity to reform the laws in accordance with human rights standards. The reformists did a good job but all their attempts failed. ${ }^{411}$

Shortly after Khatami come to force as president he provided more room for the media and diminished the scope of censorship. Such a policy helped people to be informed of violations of human rights during the past years. As a result of such efforts the chain murders of intellectuals by the fundamentalist intelligence officials were revealed as one of the systemic crimes committed by hardliners. ${ }^{412}$ Unfortunately, disappearances and murders of intellectuals continued to happen even after that incident. ${ }^{413}$

People were expecting changes especially in the human rights situation, but hardliners never let Khatami take a serious step. One can say that Khatami was not the right man to resist in such an important campaign against hardliners. Now, the Khatami of 2004 in the

\footnotetext{
${ }^{409}$ For more information about what happened in Iran during the seventh presidential election see: Sandra Mackey, supra note 7, at $393-410$.

${ }^{410}$ Cited in: $i$ ibid at 402.

${ }^{411}$ We discuss their attempts and the reason that their attempts failed. See below: sub-section 8.1.

${ }^{412}$ See: Interim report of the Special Rapporteur of the Commission on Human Rights on the situation of human rights in the Islamic Republic of Iran, UNGA Doc. A $/ 55 / 363,55^{\text {th }}$ sess., 8 Sep. 2000 , paras $59-62$, online (UNHCHR Website):

http://www.unhchr.ch/Huridocda/Huridoca.nsf/0/6c3cf24a3cc9839bc125697d004a517f/\$FILE/0063698e.d oc.

${ }^{413}$ Ibid.
} 
eyes of his ex-supporters is just a coward if he is not a traitor. ${ }^{414}$

Hardliners abusing their power in the Guardian Council ${ }^{415}$, barred reformists from running in the parliamentary election in February $2004 .{ }^{416}$ Khatami will also be removed from power in less than one year. Nothing seriously changed for the people and they are now hopeless. The reformist movement is dead. ${ }^{417}$

In this part I examine the human rights situation with respect to the question of torture after Khatami was elected as president. It must be beard in mine that the president is ruling only executive power. ${ }^{418} \mathrm{He}$ has no power over the Army, the Police, the Judiciary, Radio and Television and many other organizations which are under the non-elected fundamentalist supreme leader, Ali Khamenei. ${ }^{419}$

Hardliners accelerated the violation of human rights to prove that nothing changed after Khatami was elected as president. They abused their power over the judiciary and the police to put human rights activists under pressure. ${ }^{420}$

According to the information given by Mr. Copithorne, application of stoning to death increased after the presidential election in 1997. Three cases of stoning to death were

\footnotetext{
${ }^{414}$ For example Ibrahim Nabavi, one of the reformist journalist asked him to resign for being so feared: Ibrahim Nabavi, Khatami, Resign please, Iran Emrooz electronic daily, July 12, 2003, online (Iran Emrooz website): http://www.iran-emrooz.de/archiv/maqal/1382/nabavi820424.html

${ }^{415}$ See: supra note $412,95-98$.

${ }^{416}$ Conservatives claim victory in Iran, Sat, $21 \mathrm{Feb} 2004$, CBC News, online(CBC Website): http://www.cbc.ca/story/world/national/2004/02/21/iranvote_040221.html

${ }^{417}$ See: Babak Seradjeh, People's Demands: Present, Free Thoughts on Iran Electronic Magazine, July 29; 2003, online (FTI Website): http://freethoughts.org/archives/000022.php

${ }^{418}$ Article 134 of the Iranian Constitution: "The President is the head of the Council of Ministers. He supervises the work of the ministers and takes all necessary measures to coordinate the decisions of the government. With the cooperation of the ministers, he determines the program and policies of the government and implements the laws. In the case of discrepancies, or interferences in the constitutional duties of the government agencies, the decision of the Council of Ministers at the request of the President shall be binding provided it does not call for an interpretation of or modification in the laws. The President is responsible to the Assembly for the actions of the Council of Ministers."

${ }^{419}$ Supra note 6.

${ }^{420}$ In addition to corporal punishments such as flogging, amputation and stoning to death, the following methods have been reportedly used vastly in Iranian prisons during the last 7 years especially against political activists: solitary confinement; incommunicado detention; keeping blind-folded for a long time; suspension for long periods of time in contorted positions; burning with cigarettes; pulling out the nails; being forced to watch other prisoners being tortured; sleep deprivation; severe and repeated beatings with cables or other instruments on the back, and on the soles of the feet; beatings about the ears, inducing partial or complete deafness; punching in the eyes, leading to partial or complete blindness. See: Nigel Rodley, Report of the Special Rapporteur, UN Doc. E/CN.4/1999/61, Sess. 55 $5^{\text {th }}, 12$ Jan. 1999 para 366; see also: Habibollah Davaran \& Farhad Behbahani, supra note 349, 104 - 106
} 
reported between April and August 1997 while it has been occurring rarely since $1979 .^{421}$ Copithorne, in his 1998 report $^{422}$, considered the fact of Khatami being in power and his aim to provide an Islamic Civil Society as a positive step. ${ }^{423}$ At the same time, he drew the UN attention to the question of stoning to death. Many of them have taken place in larger cities including Tehran, Hamedan, Isfahan and Kermanshah after being endorsed by the Supreme Court. ${ }^{424}$

Hardliners, in one of their attacks against reformists, arrested Karbaschi, the then mayor of Tehran and his team charging with corruption. They were subjected to torture to obtain confession. Karbaschi's team, as victims of torture, revealed what was going on in Iran's prisons after being released. ${ }^{425}$

As a result of this incident and the release of details of torturing Karbashchi's team and students who were arrested aftermath of the July 1999 demonstrations in Towheed, secret place of detention, the first indictment for torture was brought against a police general and 10 colleagues in 1999. All were acquitted of torture but convicted of mistreatment of prisoners. ${ }^{426}$ For the first time, some Iranian officials have been acknowledging the existence of torture, and its existence in Iran is now discussed in the press. ${ }^{427}$

Based on the Special Represantative's report dated January 2000, over a two-week period, some 21 men and women were sentenced to amputation of fingers. ${ }^{428}$ Moreover,

\footnotetext{
${ }^{421}$ Situation of human rights in the Islamic Republic of Iran, UNGA Doc. A/52/472, General Assembly, $52^{\text {nd }}$ Sess.. $_{15}$ October 1997 Para 32.

${ }^{422}$ Maurice Copithorne, Report on the situation of human rights in the Islamic Republic of Iran, prepared by the Special Representative of the Commission on Human Rights, , pursuant to Commission resolution 1997/54, 54 $4^{\text {th }}$ Sess., UN Doc. E/CN.4/1998/59, 28 January 1998, online(UNHCHR Website): http:/www.unhchr.ch/Huridocda/Huridoca.nsf/TestFrame/a2ce89c52cfad182c125660a0044d404?Opendoc $\underline{\text { ument }}$

${ }^{423}$ Ibid Para 1.

${ }^{424}$ Ibid Para 21.

${ }^{425}$ See: Situation of human rights in the Islamic Republic of Iran, UNGA Doc. A/53/423, General Assembly, $53^{\text {rd }}$ ess. 23 Sep. 1998 Paras $37-40$, online(UNHCHR Website): http://www.unhchr.ch/Huridocda/Huridoca.nsf/TestFrame/8a599c1daf8f1 le6802566ac00387b32?Opendoc ument

${ }^{426}$ See: supra note 412, para 53; also see: Situation of human rights in the Islamic Republic of Iran, supra note 46 , paras $58-64$.

${ }^{427}$ Supra note 422, para $60-61$.

${ }^{428}$ Supra note 412, para 46; also see: See: Situation of human rights in the Islamic Republic of Iran, UNGA Doc. A/54/365, 54 ${ }^{\text {th }}$ Sess., 21 September 1999, para 37. online (UNHCHR Website):
} 
there were some reports on stoning to death. ${ }^{429}$

In September 2000, Copithorne became hopeful that stoning finally was declining in Iran. He had received only one such sentence in the period under review and that was apparently overturned on review. Copithorne mentioned that, in March 2000, the press quoted the Ministry of Justice spokesperson as stating that stoning may not be in the country's interest, and that the Head of the Judiciary believes that it should avoid acts which could insult the country's image. ${ }^{430}$ Iranian officials did not address the question of amputation. ${ }^{431}$

The question of corporal punishments has been addressed by the former Special Rapporteurs on torture, Mr. Nigel Rodley, criticizing corporal punishments in his reports of $1998^{432}$ and $1999^{433}$. The latter report also contains details of some torture cases that have been brought to his attention. ${ }^{434}$

In his report of 2001, Mr. Copithorne reported a positive step taken by the Head of the Judiciary who sent a circular letter to the judges with regard to torture, enumerating various types of conduct that will no longer be tolerated. Moreover, based on some reports, he has called for "the implementation of talion and retribution with their own form and formalities". ${ }^{435}$ Actually, it was a show. Severe corporal punishments continued to be practiced. Surprisingly, Iran's presidential adviser on women's issues defended the practice of stoning to death for adultery stating that it is correct based on Islamic law, in July 2002 during a meeting with. Belgium's deputy prime minister. ${ }^{436}$ It was quite unexpected to hear it from a woman in such a position in a reformist government.

http://www.unhchr.ch/Huridocda/Huridoca.nsf/TestFrame/4bbc2eb8ea9dd9868025681d00380f3e?Opendoc ument

${ }^{429}$ Situation of human rights in the Islamic Republic of Iran, ibid para 49.

${ }^{430}$ See: Situation of human rights in the Islamic Republic of Iran, supra note 412, para 57.

${ }^{431}$ Ibid para 58.

${ }^{432}$ See: Nigel Rodley, Report of the Special Rapporteur, UN Doc. E/CN.4/1998/38, Sess. $54^{\text {th }}, 24$ Dec. 1997 at 118.

${ }^{433}$ Nigel Rodley, supra note 420 para 361.

${ }^{434}$ Ibid, paras $362-366$.

${ }^{435}$ Situation of human rights in the Islamic Republic of Iran, supra note 46, para $53-54$.

${ }^{436}$ Theo Van Boven, Report of the Special Rapporteur submitted pursuant to Commission on Human Rights Resolution 2002/38, Commission on Human Rights, 58 ${ }^{\text {th }}$ Sess., UNDoc. E/CN.4/2003/68/Add.1, 27 Feb. 2003, para 686. 
Mr. Van Boven, the current Special Rapporteur on the question of torture, reported the case of Azam, a lady who was sentenced in July 2002 to have both her eyes gouged out in public, after she threw acid powder at a man who wanted to rape her and caused him to be blinded. ${ }^{437}$

\section{Sub-section 6.3.3: Journalists, political activists and students in torture chambers}

Students, journalists and political activist have been victims of torture in recent years. In this section I review some of the cases which are mentioned in various reports.

Siamak Pourzand ${ }^{438}$, an old journalist, was tried in March behind closed doors, and charged with "undermining state security through his links with monarchists and counterrevolutionaries". In May he was sentenced to 11 years in prison. Press reports said that he had confessed to his crimes at his trial, but his wife claimed that the confession was extracted under duress.

A group of political activists who were followers of Mosadeq and called the National/Religious Group was arbitrarily arrested in February of 2001, and charged with very serious offences such as espionage, spying, and attempting to overthrow the Islamic Republic. ${ }^{439}$ The judiciary announced that there is much evidence to prove their guilt. ${ }^{440}$ They have been jailed in illegal custodies, which are out of the control of any official organizations. During the first three months, they were denied communication with any lawyers, but finally, under the pressure of public opinion, they were permitted to meet with their attorneys. But these attorneys faced a number of problems. For example, one of the attorneys, Mr. Soltanian, announced that the judge would not allow him to read his client's file. $^{441}$ Finally, the accused members of this group were put to trial behind closed doors and released in April 2002. They later announced that they had been tortured, but the Revolutionary Court charged their lawyer, Mr Soltanian, with release of confidential

\footnotetext{
${ }^{437}$ Theo Van Boven, ibid, para 687.

${ }^{438}$ Theo Van Boven, ibid, paras $689-691$.

${ }^{439}$ Situation of human rights in the Islamic Republic of Iran, supra note 46,para 60.

${ }^{440}$ See: Review of a file, by S. Bastani, Bonyan Daily, April 19, 2002, No.43, at 6 online: Bonyan website< http://news.gooya.com/2002/04/18/pdf/1804-07.pdfs

${ }^{441}$ Soltanian: they want to press on me, Bonyan Daily, April 16, 2002, No.40, at 2 online: Bonyan website< http://news.gooya.com/2002/04/16/pdf/1804-07.pdf $>$
} 
information. $^{442}$

Following the student rally in Tehran University in early July 1999 protesting against shutting down a daily newspaper, namely, Salaam, police forces along with Ansar. Hezbollah militia attacked students and raided Tehran University dormitories during the night. Many students were arrested and detained while none of the violators has been prosecuted. $^{443}$

Some of the detained students such as Manoochehr Mohammadi ${ }^{444}$ and Ahmad Batebi ${ }^{445}$ are still in prison and have been subjected to severe torture as reported by the Special Rapporteur on the question of torture, Iranian newspapers and open student letters.

Ali Afshari, a student leader was arrested in May 2001 on the ridiculous charge of "attempting to overthrow the system by peaceful means". He was kept in solitary confinement and forced to confess on TV, he then withdrew all his confession claiming that he has been under torture. ${ }^{446}$

Peiman Aref, one of the student activists who were arrested in December 2002, appeared on TV in an interview confessing several crimes such as counter-revolutionary activities, organizing student movements, and so on. After being released in October 2003, he gave a lecture while an official ceremony was being held in Modarress University in Tehran to support political prisoners, and to announce that his confessions on TV were wrong. "They were given as a result of severe torture," he said. He also stated that he had been tortured for months, so severely that he had decided to commit suicide in jail in order to put an end to the pain. ${ }^{447}$

Few student associations exist as a heritage of the revolution and the battle against the Shah's tyranny. Members of the important student political activist group (Tahkim Vahdat), who represent Iranian students in almost all Iranian universities, sent a public

\footnotetext{
${ }^{442} \mathrm{Ibid}$ at 3.

${ }^{443}$ See: Situation of human rights in the Islamic Republic of Iran, supra note 428, paras 14 - 18; also see: Supra note 46 para 45.

${ }^{444}$ Theo Van Boven, Report of the Special Rapporteur on the question of torture, Commission on Human Rights, $60^{\text {th }}$ Sess., UN Doc. E/CN.4/2004/56/Add.1, 23 March 2004, para 819.

${ }^{445}$ Ibid, para 833.

${ }^{446}$ Situation of human rights in the Islamic Republic of Iran, supra note 46 para 45.

${ }^{447}$ Aref: All my confessions were wrong, ISNA news agency, 27 Oct. 2003, News no. 8208-02100, online; ISNA Website: www.isna.ir/news/newscont.asp?id=3019718\&lang=p
} 
letter to Kofi Annan, the UN Secretary General, on July 8, 2003, explaining the human rights situation in Iran. In this letter entitled "we are seeking justice" ${ }^{448}$, student representatives, after giving a complete picture of human rights violations in Iran, pointed to the question of torture.

According to this letter, torture for the purpose of extracting confession, and the degrading, insulting and belittling of political activists and students detained by the Islamic regime, is something that nobody can ignore. The students mentioned some of the popular methods of torture they experienced during their interrogations by interrogators loyal to the supreme leader. Some of the methods of torture mentioned in the letter are as follows: hard beating, flogging while being tied to the bed, deprivation of sleep for a lengthy period of time, keeping the detainee in a sitting or standing position, bringing the detainee to the execution room, or putting him in a place prepared for hanging, etc. They expressed that these methods are just the tip of the iceberg, and that nobody can truly know what happened in the places of detention which are out of any supervision. Letters from Afshari, Batebi, Sahabi, Ebrahaimi, Maleki, Jabbari, Sarkouhi and others who where brave enough to explain what happened to them, revealed just a part of the story, while a larger part will remain untold by those victims of torture who never dare to speak of it. Tahkim Vahdat announced in its letter that almost all of its members had experienced torture in Iranian custodies.

Dr. Maleki, the former president of Tehran University, sent an open letter ${ }^{449}$ to Tahkim Vahdat dated Aug 6, 2003, admitting the students' concerns about the practice of brutal investigative methods against detained students and political activists as reflected in their letter $^{450}$ to Kofi Annan. Dr. Maleki himself is one of the members of the NationalReligious group who promoted the idea of a religious political system in 1979 . Two years after the revolution, Islamic fundamentalists managed to remove all other political groups from power. Among them was the National-Religious group. Members of the

\footnotetext{
${ }^{448}$ Students' open Letter to Kofi Annan, Norooz Daily, Monday, July 8, 2003, at 1; online, Bionvan Website: www.bionvan.com/univs.php?eat $=$ news \& show $=\$ 20416-20$

449 "A drop of the sea, if it is with the sea" letter of Dr. Maleki to the Iranian students and scholars, Press Release: SMCCD Political Committee, Tuesday August 12, 2003; online, Scoop website: http://www.scoop.co.nz/mason/stories/WO0308/S00127.htm ${ }^{450}$ Supra note 448 .
} 
mentioned group have been imprisoned, and tortured from time to time.

Maleki, in his letter entitled "a drop is the sea, if it is with the sea", acknowledged the accuracy of the students' claim in their letter to Kofi Annan by reviewing some of his own experiences of being tortured while he was in jail between 1981 and 1986, and again from 2000 to 2003 . $^{451}$

In part of his letter, he admires students' attempts to help their fellow students who are in torture chambers. According to Maleki, these students are entitled to be worried about their friends when they learned such information as the fate of a lady reporter (Zahra Kazemi) who was put in a torture chamber, or when they hear from the sidelines what may happen to male or female students in these rooms, or when they hear from their elders how confessions are extracted in horrific jail houses under the tyranny of the supreme leader. In the other parts of his letter, Maleki explains his own experience, giving us a comprehensive perspective of what had occurred, if only during that specific period of time. He states:

"I know. I know very well how it burns to your core every time the cable strikes the soles of your feet or any other part of your body. I know very well how your personality and you whole existence is stirred and disturbed when you are taken blindfolded into the interrogation room and the guard closes the door. You can't see anywhere or anybody, the interrogators' hard slap throws you off your balance and you hit the wall hard and you spill on the floor and writhe in pain, you hear the voice of the interrogator who grabs your head by the hair and pulls you up to your feet as he shouts obscenities saying "DON'T PLAY DEAD YOU PIECE OF SULLEN DIRT. SIT ON THE CHAIR AND ANSWER ME."

I know very well what nightly interrogations mean and how the interrogators in the middle of the night treat the tired and worried prisoners. I know very well, if you happen to be young and

\footnotetext{
${ }^{451}$ Dr Maleki's biography, online; Mellimazhabi website, http://www.mellimazhabi.org/biography/maleki/maleki.htm
} 
inexperienced, how they can frighten you and trick you into writing and admitting whatever they say. I know. I know very well what "repentant making" means and how they make a repentant out of an innocent prisoner as they make him confess to thousands of sins he did not commit. I know very well what the mind-altering drugs, which they inject into prisoners, can do to your brain, mind, and senses. To the point that you start believing that you have been a spy in the service of Imperialism and "World Arrogance (USA)" since birth!"

There are some specific points that make his letter considerably important:

1 He dares to explain the different methods of torture in detail, and even points at both white and black torture.

2 He dares to target the supreme leader as the one who is responsible for all these crimes, and the one who supports torturers, resisting any reform in legal texts toward eradicating torture by using his power through the Guardian Council.

3 He confesses in part of his letter that he and his fellow revolutionaries made a big mistake during the revolution while they fought a dictator and a fascist instead of fighting dictatorship and fascism. They only replaced a "king's tyranny" with a "religious tyranny".

\section{Sub-section 6.3.4: Reviewing two famous cases}

There are two famous cases about torture that remain unfinished in the Iranian judiciary. I believe that reviewing these cases based on available sources can explain the scope of the problem of using torture in Iranian prisons.

Part 6.3.4.1: Saeed Emami's wife case

Like other totalitarian governments, fundamental Islamists started to kill intellectuals and human rights activists out of jail. Chain murders, which happened during the fall of 1998 in Iran, can be nominated as one of the most terrible crimes against humanity in the 
world. ${ }^{452}$ A number of high-ranking agents of the Intelligence Ministry were involved in killing numerous intellectuals, writers, journalists and human rights activists. ${ }^{453}$ Right after information of such horrible crimes committed by the agents who are supervised by the supreme leader was released, the Iranian authorities announced that "rogue elements" in the Intelligence Ministry had carried out the killings. ${ }^{454}$ Ali Khamenei, the leader, delivered a speech during the Friday prayer and claimed that these agents had been Israeli and American spies who penetrated the Intelligence Ministry and committed such crimes in order put blame on the Islamic regime. ${ }^{455}$ It was the beginning of a process investigated by the judiciary to prove that the leader is right - murders have been out of the control of the ministry, and the perpetrators followed orders from their masters in Israel and the U.S. as part of a plot against the Islamic Republic of Iran. Saeed Emami, one of the key detained agents who was a deputy minister died in prison a few days later, reportedly due to suicide. Other detained agents, as well as the Saeed Emami's wife, were put under serious torture to confess, according to the leader's idea. Other former agents in the Ministry of Intelligence helped their friends by releasing a documentary film on the internet which demonstrated how the detainees, especially Emami's wife, were tortured physically and psychologically to confess that they were Israeli spies who were instructed to kill writers and journalists in Iran as a part of a plot against the Islamic regime. $^{456}$

\section{Part 6.3.4.2: Zahra Kazemi case}

Zahra Kazemi, a Canadian-Iranian photo-journalist, died in Evin prison in Tehran on July

\footnotetext{
${ }^{452}$ The situation of human rights in the Islamic Republic of Iran, UNJAOR, $54^{\text {th }}$ Sess, UN Doc A/54/364, (Sep.1999) at 39-44.

${ }^{453}$ The situation of human rights in the Islamic Republic of Iran, supra note 412 paras 59-62.

${ }^{454}$ Amnesty International, Annual Report on Iran 1999, online: http://www.amnesty.org/ailib/aireport/ar99/mde13.htm. Also see: Amnesty International, Annual Report on Iran 2000, online: http://www.web.amnesty.org/web/ar2000web.nsf/f5ea2b18926bc708802568f500619c95/2f122285cde39a9 4802568f200552931! OpenDocument For more information see: Commission on Human Rights Resolution, supra note 30 para 48.

455 "Ali Khamenei, the supreme leader of Iran: Murders were against Iran's nation and government", Hamshahri Daily, No.1738, 10 Jan. 1999, at 1. online: http://www.hamshahri.org.

${ }^{456}$ The content of the interrogation as well as videos are available online: http://www.londonfreelance.org//ran/videos.html
} 
10,2003 , after being detained by the security forces for taking photos outside the prison during student-led protests against Islamic hardliners. ${ }^{457}$

Kazemi's death became a part of a bitter power struggle between reformists and conservatives. Khatami, the reformist president, interfered in the case by appointing a committee to seek the truth in the matter. The president-appointed committee concluded that Kazemi died of head injuries sustained while in custody. ${ }^{458}$ In a separate letter Khatami asked the Head of the Judiciary to find the truth. ${ }^{459}$

Mortazavi, a Tehran general prosecutor, initially said Kazemi died of a stroke. He tried to push agents of the Guidance Ministry to announce that Kazemi had no permission to work in Iran as a journalist, and that she had been spying for foreigners.

Human rights activists, members of Kazemi's family, and most of the reformists, accused Mortazavi, but the judiciary denies his role, claiming that Mohammad Reza Moghaddam, an agent with the reformist-controlled Intelligence Ministry, is responsible for torturing her. They charged him with "semi- premeditated murder". ${ }^{460}$

The Parliamentary Committee of article 90 of the Constitution, that has the power to investigate all complaints of the public against government organizations, released a report on Zahra Kazemi's case. ${ }^{461}$ This report explained the details of the case and accused Mortazavi of fabricating evidence in order to cover the reality of Kazemi's case.

\footnotetext{
${ }^{457}$ See: Theo Van Boven, supra note 444, para 806, see also: Amnesty International, Iran: Only an independent investigative body can serve justice and human rights, AI Index: MDE 13/026/2003 (Public), 1 August 2003.

${ }^{458}$ See: Report of President's Special Committee on Zahra Kazemi's death, Hamshahri Daily, No. 3113, Monday July 21, 2003, online (Hamshahri website): http://www.hamshahri.org/hamnews/1382/820430/news/siasi.htm\#s14255, for a complete report on the detail of what president Khatami did on this case see: About Zahra Kazemi's File, by Mohammad Ali Abtahi (Vice President to Mr. Khatami), July 16, 2004, an article on his weblog, online: http://www.webnevesht.com/weblog/?id=1090066798

459 "Khatami Wrote to Shahroodi: Who is the murderer", Hamshahri Daily, no. 3114, Tuesday July 22, 2003, online (Hamshahri website): http://www.hamshahri.org/hamnews/1382/820431/news/siasi.htm\#s14780

460 "Kazemi Murder Enquiry Farce Continues As Court Says Only One Person Responsible", Middle East Press Released, Reporters Without Borders, Article 8092, Sep. 26, 2003; Online: www.rsf.org/article.php3?id_article $=8092$

${ }^{461}$ For complete text in Persian see Mehr News Website: http://www.mehrnews.ir/fa/NewsPrint.aspx?NewsID=33799, for English version of the report see: Iran reformists denounce judges, by Jim Muir (BBC reporter in Tehran),Tuesday, 28 October, 2003, online (BBC website): http://news.bbc.co.uk/1/hi/world/middle_east/3220173.stm
} 
According to this report, all official prison documents that had recorded all events in the prison had been manipulated. The committee clearly accused Mortazavi and the judiciary of failing to justify Kazemi's arrest on charges of espionage. It demanded to know why Mortazavi had originally attributed Kazemi's death to a stroke, when she was later found to have died from a blow to the head. The committee expressed the opinion that there were deliberate attempts by Mortazavi to justify Kazemi's death. Making witnesses withdraw their testimonies were among those attempts. ${ }^{462}$ The report also pointed to notes written by Kazemi while in prison in which she complained of being tortured.

In spite of pressure from the Canadian government, international organizations, president Khatami and Kazemi's family, none of the judicial officials including Mortazavi faced charges. The trial of the only accused person, Moghadam, took place on July 2004. The lawyers of Kazemi's family including the Nobel Peace Prize winner, Shirin Ebadi ${ }^{463}$, were criticizing seriously the competence of the court. ${ }^{464}$ Their objection to the competence was refused. The lawyers of the victim's family objected against way of hearing, The lack of proper investigation and the fact that there are many other accused persons in relation with this murder and the court did not even ask them to show up. ${ }^{465}$ The accused person was found not guilty based on the court's final verdict. In this verdict, court says that no one can be found guilty in this regard and the government will pay a specific amount of money to the victim's family. ${ }^{466}$ The Canadian government as well as Kazemi's son refused the courts' verdict. Kazemi's son asked Canadian Government to take Kazemi's case to the International Court of Justice and to expel the Iranian ambassador to Canada. ${ }^{467}$ Canadian Government recalled its ambassador to Iran

\footnotetext{
${ }^{462}$ See: Mohsen Armin (A member of Parliamentary National Defence Committee in sixth parliament), Report on Zahra Kazem's murder, Official speach in Parliament, Sunday, July. 20, 2003.

${ }^{463}$ The Nobel Peace Prize, The Norwegian Nobel Committee, Press Release, Oslo, Oct. 10, 2003; Online: www.nobel.se/peace/laureates2003/press.html

${ }^{464}$ Kazemi's family Lawyers: The Court is not Competent to Hear the Case, ISNA news agency, Thu 1507 04,

${ }^{465}$ To read a complete report on what happened in the court see: Call for presence of witnesses in the court, Shargh Daily, July 18, 2004, online (Shargh Website): http://www.shargh.ws/830428/index.htm

${ }^{466}$ Court: No body is guilty, Shargh Daily, July 25, 2004, online (Shargh Website): http://www.shargh.ws/830504/index.htm

${ }^{467}$ 'Minister failed me, 'Kazemi's son says, Online news CBC Montreal, Jul 28 2004, online(CBC website): http://montreal.cbc.ca/regional/servlet/View?filename $=\mathrm{qc} \_\mathrm{kaz} 20040728$
} 
protesting to the attempts made by Iranian court to hide the truth. ${ }^{468}$

\section{Sub-section 6.3.5: Islamic Republic Constitution}

The Iranian Constitution ${ }^{469}$ of 1979 was approved shortly after the victory of the Islamic revolution in Iran. ${ }^{470}$ Most of the political activists who were sitting as lawmakers had experienced torture in the prisons of the previous regime. Moreover, they knew that the question of torture is always more complicated when there is any political conflict between people and government. As a result, they attempted to completely ban torture. ${ }^{471}$ Article 38 of the Iranian Constitution reads:

"All forms of torture for the purpose of extracting confession or acquiring information are forbidden. Compulsion of individuals to testify, confess, or take an oath is not permissible; and any testimony, confession, or oath obtained under duress is devoid of value and credence. Violation of this article is liable to punishment in accordance with the law"

This article is located in the chapter on People's Rights. This chapter of the Constitution describes the rights of people against the government.

The drafting of this article causes a kind of confusion. Reading this article, one may conclude that if the purpose of torture will not be for extracting confessions, or for acquiring information, it would be allowed for any other means. But in reviewing the negotiations leading to the approval of this article, it is illustrated that this is not true, and that this article in fact covers all kinds of torture, both physical and non-physical for any purposes.

\footnotetext{
${ }^{468}$ Canada recalls ambassador from Iran, $\mathrm{CBC}$ News, Tue, 23 Jul 2003, Online(CBC website): http://montreal.cbc.ca/regional/servlet/View?filename $=q c$ kazemi20030723

${ }^{469}$ Islamic Republic of Iran Constitution, Adopted on: 24 Oct 1979, Effective since: 3 Dec 1979, Amended on: 28 July 1989, available online(Iran Embassy in Ottawa website): http://www.salamiran.org/IranInfo/State/Constitution/

${ }^{470}$ For more information about Iran's current constitution see: Abolfazl Ghazi, Constitutional Law and Political Institutions, $1^{\text {st }}$ ed. (Tehran: Tehran University Press, 1991).

471 "Torture in Iran" an interview with Kambiz Noroozi, Bonyan newspaper, no 20, March 8, 2002 at 4.
} 
Regarding Article 4 of the Constitution ${ }^{472}$, the scope of the torture definition as the Iranian lawmakers meant it does not fit the international definition. Brutal punishments after trial, which are allowed in traditional Islamic Law, are not considered as torture in their eyes. These kinds of punishments are beyond the definition of torture in the Iranian legal system.

Article 38 of the Constitution was the subject of negotiation in the $30^{\text {th }}$ session of the Iranian Constitutional Assembly on Sep. 26, 1979. ${ }^{473}$ The first draft of the article was as follows:

"Torture for the purpose of extracting confession or acquiring information is forbidden. Compulsion of individuals to testify, confess, or take an oath is not permissible; and any testimony, confession, or oath obtained under duress is devoid of value and credence. Violation of this article is liable to punishment in accordance with the law" 474

One of the deputies, during the drafting negotiations, suggested that it is better to say "any torture ...", while another deputy replied that the phrase "any torture ..." may only represent corporal tortures, and that it is better to say "torture of any type ...", as the intent is to ban all kinds of torture, including corporal, mental and psychological torture. $^{475}$

Meshkini, one of the hardliner clergies, now one of the powerful clergies in Iran, suggested that:

"In some cases by using a little pressure to the detainee you may find out very important information. So sometimes you can use a bad thing like torture to prevent a worst thing from happening. I believe it is

\footnotetext{
${ }^{472}$ Article 4: "All civil, penal financial, economic, administrative, cultural, military, political, and other laws and regulations must be based on Islamic criteria. This principle applies absolutely and generally to all articles of the Constitution as well as to all other laws and regulations, and the fuqaha' of the Guardian Council are judges in this matter."

${ }^{473}$ The Entire Negotiations During the Final Assessing of the Islamic Republic of Iran Constitution, Vol. 1, (Tehran: Parliament Publishing, 1985) at 619-20, online; GC website: http://www.irisn.com/ketabkhaneh/mashroh/01/MATN_MASHROH_MOZARAKERAT 30.HTM ${ }^{474}$ Ibid at $619-20$.

${ }^{475} \mathrm{Ibid}$ at $619-20$ \& 778 .
} 
better not to say that torture is absolutely banned." 476

Ayatollah Montazeri ${ }^{477}$, the head of the assembly, who was released from his house arrest of 5 years in the summer of 2003, replied, "Damages of such a policy are more than its possible benefits". ${ }^{478}$ The first vice president of the Assembly, Ayatollah Dr. Beheshti, supported Montazeri's idea by saying that:

"No matter how beneficial such a policy is, the real question is that you will open a way of torturing people. If we accept torture in some very special cases, be sure that torture will be used vastly. If we legitimize a very light torture to a very dangerous criminal it means that we have opened the way for torturing all detainees whatsoever" 479

Montazeri added another argument to Beheshti's comment insisting, "If a guilty person escapes from justice it is better than punishing an innocent". 480

Finally the members of the assembly approved Article 38 as "all forms of torture ..." the same phrase that we currently have in Article 38 of the Constitution, by 50 votes to 12 abstention votes, with no votes against. ${ }^{481}$

This approval with no opposing votes means that even hard line deputies such as Meshkini have accepted the dominant idea of an absolute ban on torture. So, nobody can claim that there is any ground in the Iranian Constitution to justify any kind of torture, from physical and psychological, to any newly invented methods which could not be imagined by the legislators at that time. In addition to such a strong ban on torture, the Iranian Constitution, like other modern legal systems, invalidated all information,

\footnotetext{
${ }^{476}$ Supra note 473 at 778.

${ }^{477} \mathrm{He}$ was the second powerful person in the first decade after the revolution but after violation of human rights in prisons and execution of thousands of people by the order of Khomeini in 1988, he protested against him and lost his position in the government. Now he is accepted by people as a very high ranking clergy known as Marja. He and his late son were tortured badly in the Shah's prisons for a long time; he is now opposing the supreme leader supporting human rights and democracy in Iran. For more information about him see: Ayatollah Hussein Ali Montazeri, supra note 3.

${ }^{478}$ Supra note 473 at $619-20 \& 778$.

${ }^{479}$ Supra note 473 at 778.

${ }^{480}$ Ibid.

481 Jalalodin Madani, Islamic Republic of Iran's Constitution, Vol. 1, (Tehran: Ganje Danesh Press, 1990) at 250.
} 
confessions, and oaths achieved under use of torture.

According to this article, the purpose of torture is not limited to the purpose of making an accused person confess. It can also be practiced to make him give testimony, either for or against an individual, or to derive an oath. Article 38 banned torture absolutely and criminalized it, stating that anyone who commits such a terrible crime must be punished according to the law.

Regarding these negotiations as the most important source for the interpretation of the Iranian Constitution $^{482}$, Iranian lawyers strongly believe that torturing people for any reason is absolutely banned and illegal in Iranian Constitutional law. ${ }^{483}$

Regarding the fact that the Iranian Constitution has banned torture strongly, Maurice Kopithorne, in his report of 2000 , called on the Iranian government to apply the Iranian Constitution and international norms in order to uphold the ban on torture. ${ }^{484}$

\section{Sub-section 6.3.6: Parliamentary laws}

Although the Constitution banned torture firmly and absolutely, it does not give a clear definition. This question remained untouched in Iranian laws. They failed to give a specific definition of torture, regulations to ban torture absolutely, and complete safeguards to prevent torture. ${ }^{485}$ In this section, I will review some Iranian laws linked to the question of torture.

The Tazirat Code $^{486}(1980)$ is among the series of Islamic laws which were approved shortly after the establishment of the Islamic Republic of Iran, as one of the important goals of the Islamists. Section 58 of this code substituted section 131 of the Public Punishment Code $^{487}$. It stipulates that:

\footnotetext{
${ }^{482}$ Abolfazl Ghazi, supra note 470 at 759.

483: "Comments on Bill to Join Iran to the UN Convention Against Torture" legal studies bureau of the parliament research center, khaneh Mellat daily, Monday Aug. 7, 2003. online: http://mellat.majlis.ir/archive/1382/researchcenter/hoghooghi/news1.htm; also see: supra note 474. 
"public officials, judicial or non-judicial, who torture or order to torture a detainee or a prisoner in order to obtain confession or other information shall be sentenced to jail for 6 months to 6 years. If the victim dies as a result of torture it is considered as a murder. The torturer shall be sentenced as a murderer and superior officials who ordered him to torture shall be sentenced as who ordered to murder"

The Iranian legislature clarified the elements of the crime of torture, but did not go so far as to thoroughly examine methods of torture. It covers only one type of torture, which is corporal torture, while the Constitution banned corporal torture as well as other possible kinds of torture. ${ }^{488}$

Further, this section pointed to only one purpose of torture, which is "to make the accused confess". It can then be interpreted that in the case that a detainee is tortured for any other purpose the torturers would therefore not be punished according to this section. Of course, such an interpretation is against the Constitution that counts more than one possible purpose for torture, as discussed before.

Section 62 of Tazirat Code substituted section 136 of the Public punishment Code ${ }^{489}$. In the later section the Islamic parliament changed the punishment to the Islamic types such as retaliation and flogging. I think this section is very interesting and deserves attention in order to make the difference between the two definitions, namely international law and Iranian law, clear. ${ }^{490}$

Another important section in Tazirat Code is section 59. This section, which is an exact translation of a religious rule, reads:

"if the governmental employee who is in charge of executing the punishment, punishes the sentenced offender more severely or does more than what he should do with regard to the court sentence, the court shall sentence him to retaliation or jail for a period of 6 months to 3 years and if what he has done is a specific crime according to the

\footnotetext{
${ }^{488}$ S. A. Mousavi, supra note 314.

${ }^{489}$ Supra note 326.

${ }^{490}$ For definition of torture see below: section 4.1 .
} 
law he will be sentenced to be punished for that crime as well"

I mentioned this section to show that no corporal punishment can be accepted. Even if an offender is sentenced to be punished, no one can impose on him something more than what he has been sentenced to.

Section 79 of the Tazirat Code repeated the content of its predecessor, which was section 194 of the Public Punishment Code, but it is again an Islamic copy of that section, as punishments have been changed to retaliation and flogging. There are many other sections in this Code that prescribe flogging as punishment for a long list of offences. Corporal punishments are prescribed in several sections.

Section 11 defines the concept of Tazirat. It describes Tazirat as punishments whose forms and degree of severity are not determined by the Islamic law. It is judge who should decide about all elements of those punishments. It can be applied in form of imprisonment, flogging or financial penalties. The severity of Tazirat shall not exceed the severity of Hodood. For example, flogging as Tazir shall not be more than 74 lashes because the minimum punishment for Hodood is 75 lashes.

The Hodood \& Qisas Code $^{491}$ approved in 1982 contains many sections addressing to corporal punishments. This Code which is an exact translation of Shia jurisprudence is all about retaliation, amputation and flogging. Based on sections 43 to 80 , retaliation will be considered as an authorized punishment for murder and causing injuries to the victim's body. Retaliation is capable to be replaced with Dieh, a specific amount of money that should be paid to the victim as compensation.

Section 99 describes adultery. If a married man or woman committed such a crime under specific circumstances he or she may be sentenced to death by stoning (section 100). The way to carry out stoning has been explained in section 117. Flogging is a punishment for variety of crimes like adultery in the case of unmarried people, drinking alcohol and in some cases of robbery etc.

Amputation of fingers, limbs, hands or feet is prescribed for robbery in certain conditions. For sodomy, based on section 141, the judge shall sentence the offender to death but it is

\footnotetext{
${ }^{491}$ Hodood \& Qisas Code, Judicial Committee to the National Parliament, approved 11 Oct. 1982, Official Gazette 10987. online (Ghavanin Website): http://www.ghavanin.com/detail.asp?id=1086
} 
him who determines the way of execution. Finally according to section 196, Mohareb (armed fighter) and mofsed (the one who spread corruption on the ground) may be sentenced to death or crossing for three days (section 207) or cutting the right hand and left foot or being sent to exile.

Section 53 of the Punishment of Military Offences $\mathrm{Act}^{492}$ is the Islamic version of section 384 of Military Judicial Procedure and Punishment Act. ${ }^{493}$ This new version is more progressive than the previous ones. It extended the scope of the subject from torture and physical damages to psychological torture as well. Moreover, because hurting people is forbidden in Islam, appropriate Islamic punishments (retaliation or Qisas) would be applied in addition to a period of 6 months to 3 years in prison. The scope of that law is limited to military courts.

A new punishment law was approved in 1991 called The Islamic Criminal Code ${ }^{494}$. Section 578 of the mentioned law is a more Islamized content of section 58 of the Tazirat Code of $1980 .^{495}$ The punishments are changed to the Islamic retaliation rules (Qisas), and Islamic Compensation (Dieh). In addition to Islamic punishments, a punishment of 6 months to 3 years in jail may be applied as a supplementary punishment. It is a significant step backward, exempting some torturers from punishment. It reads:

"If one of the governmental judicial or non-judicial officials tortures an accused physically in order to make him confess in addition to - retaliation(Qisas) and paying compensation(Dieh), he shall be sentenced to jail for 6 months to 3 years. In a case that somebody is ordered to torture an accused, only the person who ordered shall be punished. If the detainee was tortured to death, the torturer will be punished as he who committed murder, and those who ordered it shall be punished as those who ordered a murder"

\footnotetext{
${ }^{492}$ Punishment of Military Offences Act, Islamic Parliament, January 17, 2003, online (Iran Military Court website): http://www.iranmilitarycourt.com/military/document/lows/6.htm

${ }^{493}$ Supra note 342.

${ }^{494}$ Islamic Criminal Code, July 29, 1991, approved by the Judicial Committee to the Parliament and amended Nov. 27, 1991 by Expediency Council, Official Gazette no. 13640, January 1, 1991.

${ }^{495}$ Supra note 486.
} 
This code does not contain any section similar to section 79 of Tazirat Code, which covers torture of a detainee who is arbitrarily arrested.

Section 579 of the mentioned law is about punishing the offenders more than what has been sanctioned by the law and sentenced by the court. The official who is responsible for carrying out the convicted punishments may commit such a crime. According to this section, the official must be punished according to the Islamic retaliation rules and has to pay the Islamic compensation. Corporal punishments repeated in this Code again.

There are five separate chapters in this Code. Chapter 2 is all about Hodood with almost the same content as in Hodood \& Qisas Code. For example, flogging may apply for crimes of adultery, robbery, drinking alcohol, pimping and assaulting another Muslim based on sections 63-218. Stoning also mentioned in relation to adultery of a married person (section 83). Chapter three is all about Qisas with almost the same content as in Hodood \& Qisas Code.

New laws continued to emerge in order to bring the Iranian penal law closer and closer to Islamic law. It seems that fundamentalists never stop reviewing the laws but, surprisingly, these reviews never seem to result in better laws.

In 1996, the Islamic Parliament passed another Islamic Criminal Code ${ }^{496}$. It did not add anything special to the previous laws, and sections 578 and 579 merely repeated the content of sections 578 and 579 of the old version.

Section 587 of the new code reads:

"if a person who committed crimes mentioned in sections 570-587 of this Code, had threatened the detainee to death or tortured him or hurt him physically, he will be sentenced to jail for 1-5 years and deprived of government services in addition to Islamic compensation if applicable."

One can say that, in this code, legislators accepted that the threat of death, which may cause a kind of psychological torture, is thus torture. It is very close to the contents of article 194 of the Public Punishment Code, which was missing in previous versions of

\footnotetext{
${ }^{496}$ Islamic Criminal Code, Islamic Parliament, May 22, 1996, online(Ghavanin Website): http://www.ghavanin.com/detail.asp?id=1232
} 
Islamic Codes.

This Code is based on Islamic law and comparing to its predecessors there are no changes in it in the matter of corporal punishments. Flogging, stoning, amputation and retaliation are accepted for a variety of crimes.

In October 1997, Mr. Copithorne ${ }^{497}$ expresses his concern about the question of stoning which is recognized in article 82 of the Islamic Criminal Code as punishment for adultery by a married person.

Maurice Copithorne ${ }^{498}$ has been told by Iranian officials that this new Code is softened but he noticed that corporal punishments which are clearly are contrary to existing international norms have been included in the new Code.

Copithorne stated in his report that mentioning corporal punishments, in particular stoning, in the Islamic Criminal Code do not make them "lawful sanctions", but it serves to encourage recourse to such punishments. ${ }^{499}$ According to him $^{500}$, there is no doubt that stoning is a cruel, inhuman or degrading punishment; he urges the Government of the Islamic Republic of Iran to remove article 82 (b) from the Islamic Criminal Code.

Regardless of Copithorne's calling for ending such a severe corporal punishments, the Parliament re-promulgated them in the Procedures in the General and Revolutionary Courts Code ${ }^{501}$.

The content of section 129 of the Procedure of General and Revolutionary Courts $\mathrm{Code}^{502}$, is similar to the content of its predecessor, section 125 of the Revising a Part of Criminal Procedure Code ${ }^{503}$ of 1957 (Iranian year of 1338), stating that a prosecutor cannot make an accused confess, and that the accused has the right to silence. Asking empathic questions, deceiving the accused and the use of coercion or force are forbidden. As $I$ argued above, according to the laws approved before the Islamic Revolution, a lawyer could accompany his or her client during the investigation process and in his or

\footnotetext{
${ }^{497}$ Situation of human rights in the Islamic Republic of Iran, supra note 421.

${ }^{498}$ Maurice Copithorne, supra note 408, Para 38.

${ }^{499}$ Situation of human rights in the Islamic Republic of Iran, supra note 421, Para 33.

${ }^{500}$ Ibid para 34.

${ }^{501}$ The Procedures in the General and Revolutionary Courts Code, Official Gazette 1591, 10 October 1999 ${ }^{502}$ Ibid

${ }^{503}$ Code of Revising A Part of Criminal Procedure, supra note 339.
} 
her trial. However, section 128 of the Procedure of General and Revolutionary Courts Code admitted almost the same content on the one hand, yet diminished such an absolute right on the other hand, and stepped backward by adding:

"... If the subject of hearing is confidential (with regard to security measures) or the attendance of people other than the accused causes immoral consequences according to the judge, moreover, if the crime is against national security, the lawyer's attendance in the interrogation process will be subjected to the court's permission"

Therefore, the right of the accused to be accompanied by a lawyer can be violated easily by the court, and one of the most important safeguards would be missed by the absence of a lawyer in the interrogation session. As nearly any case can be defined as a case with an immoral subject or a case against national security, this can jeopardize the rights of the accused and put him in a position to be tortured. This is exactly what happened to political detainees, the most vulnerable people in this regard. Maurice Copithorne in his report $^{504}$ of 2001 addressed the abuse of the situation in a number of cases. ${ }^{505}$

Even if the accused is lucky enough to have a lawyer, and his lawyer is to accompany him, according to section 128 of the mentioned code, he should not interfere in the process of interrogation. He can only give his comments, which are necessary to find the truth, to defend his client, or to implement laws; at the end of the interrogation session his comments must be recorded in the detainee's file. The important point here is that a lawyer's presence may prevent interrogators from inflicting ill-treatment for fear of

${ }^{504}$ Report of the special representative of the Commission of Human Rights on the situation of human rights in the Islamic Republic of Iran, supra note 46.

${ }^{505}$ Some of these cases are as follow: 1- National-religious group members: They have been denied the right to legal counsel during and after prolonged interrogations. 2- Ali Afshari: a detained student who were obliged to confess on TV on 16 May 2001 before he had been charged legally; he also was denied the right to legal assistance for a long period of time. (for more information about him also see: Nigel Rodley, Report of the Special Rapporteur submitted pursuant to Commission on Human Rights Resolution 2000/43, Commission on Human Rights, 57 ${ }^{\text {th }}$ Sess., UNDoc. E/CN.4/2001/66, 25 Jan. 2001, para 627) 3- Siamak Poorzand, a 73-year-old former journalist and writer, who has been kidnapped by the Revolutionary Courts' agents late 2001. After six months, the judiciary accepted that he was arrested by the agents. He was also denied the right to legal assistance and has been charged with several serious offences such as espionage and threatening national security and spying. For more information about Poorzand see: Iranian exjournalist put on trial on spying charges, The New York Times, Friday, March 15, 2002 online: http://www.iht.com/articles/51340.htm also see: A journalist at Risk, Human Rights Watch News, New York, December 22, 2001online: http://www.hrw.org/press/2001/12/iran122201.htm 
documentation of their behavior by the present lawyer.

Another legal text that emphasizes banning torture in the Iranian legal system is the Permission for the Iranian Government to Join the Convention on the Rights of the Child $\mathrm{Code}^{506}(1993)$. Section 37 of the mentioned law reads; "no child can be subjected to torture, inhuman or degrading treatment".

\section{Sub-section 6.3.7: Bylaws}

After the Islamic revolution, but before there was an opportunity to pass laws in parliament, revolutionary leaders come to approve some regulations through the Revolution Council. One of these regulations was the Islamic Revolutionary Courts Bylaw $^{507}$. Section 2 of the above-mentioned bylaw stipulated mandates of the revolutionary courts. Hearing cases against torturers or some who ordered to imprison or torture revolutionary people is included in the revolutionary courts' mandates.

The preamble of the bylaw stipulates:

“...these courts are established in order to hear cases related to crimes committed with regard to empower the Shah's regime and facilitate the influence of other countries in Iran before the Islamic revolution as well as crimes against the Islamic revolution in the past, present and future"

It is hard to say that the revolutionary legislators provided Iranian law with a clear and absolute text against torture. They did not established a special court for torture. On the contrary, Islamic Revolutionary Courts are special courts, whose existence is not in accordance with the Constitution, and are responsible for torturing the majority of political activists deemed anti-revolutionaries, or those who opposed Islam or Velayate Faghih (Islamic Government in Shia Faith). The prosecutors, judges and employees of these courts are accused of participating in the front line of torture in Iran due to the fact that all political prisoners are prosecuted by the revolutionary courts. The existence of such a bylaw is showing a kind of paradox which revolutionaries are facing. On the one

\footnotetext{
${ }^{506}$ Permission for the Iranian Government to Join the Convention on the Rights of the Child Code, National Parliament, Feb. 19, 1993, online (Ghavanin website): http://www.ghavanin.com/detail.asp?id=8649

${ }^{507}$ Islamic Revolutionary Courts Bylaw, Revolutionary Counsil, 1979, Official Gazette, No. 7/2482.
} 
hand, they were seeking a way to punish some who tortured them in the Shah's prisons, but on the other hand, they do not apply their judgment about torturers before the revolution to the torturers after the revolution.

The Prisons and Security and Correctional Measures Organization Bylaw ${ }^{508}$ is another bylaw related to the topic, which was approved after the revolution. Section 146 stipulates that:

“...assaulting, witting, degrading the prisoners, using insulting language against them and any physical disciplinary punishment is forbidden. In addition, any kind of violent, painful and assaulting scouring and use of metal instruments such as chain that are against Islamic rules and human rights is forbidden completely. Only shackles can be used in certain cases."

There is no sanction in case of violation and no supervision offered in this text to guarantee its application.

${ }^{508}$ Prisons and Security and Correctional Measures Organization Bylaw, assembly of Ministers, Aug. 29, 1982, Official Gazette No. 10924. 


\section{Chapter 7: Examining the Iranian legal system with regard to the international standards on torture}

In the Iranian legal system, torture is absolutely banned, and no kind of torture for any reason can be applied to the detainees according to article 38 of the Constitution. Moreover, all information, confessions, or oaths are not valid if achieved through use of torture. The Constitution fulfilled its function as a major law, but left other aspects, such as clearly defining torture, and providing sanctions and measures to prevent torture, for parliamentary laws. However, these laws are not complete. They focus on physical tortures and prescribed serious punishments, but there are not enough safeguards to protect people from being tortured, and no serious control or supervision is prescribed on prisons and custodies. Besides, the question of corporal punishment is crucial. It is a serious controversial point. As we discussed, Iranian penal law is full of provisions that authorize applying these punishments which is not in accordance with international standards.

\section{Section 7.1: Definition of Torture in the Iranian Legal System}

There is no specific definition of torture in Iranian law or Islamic law. Neither the Iranian Constitution nor parliamentary laws try to define torture. Even new bills ${ }^{509}$ tabled by reformists to ban torture do not give any definition. However, there is no doubt that corporal punishments after trial are not categorized as torture in Iranian law as well as in Islamic law. ${ }^{510}$ I recall section 62 of the Tazirat Code which I have discussed before. ${ }^{511}$ This section states that a torturer may be punished by flogging. It is a good example to clarify the difference of definition in international law and Iranian law. ${ }^{512}$ Corporal

\footnotetext{
${ }^{509}$ See below: sub-sections 8.1.1. - 8.1.3.

${ }^{510}$ Iranian government on Jan. 22, 1991, denied any physical abuse or torture in prisons stating that corporal punishments in Iran, flogging, stoning, amputation and Quesas (retaliation), are among divine punishments permitted by Islam for certain crimes. Actually, in this letter Iranian government stated on the controversial debate on definition of torture. In their eyes brutal punishments are not torture. See: Reynaldo Galindo Pohl, supra note 363 , para 74.

S11 See above: sub-section 6.3.6.

${ }^{512}$ Mohammad Ali Ardebili, "Torture" in Legal Research Review, International Law studies Center, vol. 45, July 1999 , at 191 .
} 
punishment, which is defined as torture in international law, is not considered torture in both Islamic jurisprudence and Iranian law. In the eyes of international law, section 62 describes punishing a torturer by torturing him.

From an Islamic point of view, a torturer is punished because he tortured a detainee or a prisoner to make him confess, or for any other purpose, and this is a crime according to the law. The accused is tried and is found guilty, and one of the punishments prescribed by law is flogging for a specific amount of lashes. Confession is not the intention of this punishment; rather it is simply punishment according to the law where, if applied after the accused is convicted, it is not seen as torture.

One must bear in mind that Islamic fundamentalists in Iran found the Islamic term of Tazir $^{513}$ as a valuable term to abuse in order to justify torture. ${ }^{514}$

According to the ex-prisoners' memoirs ${ }^{515}$, torturers were claiming that the prisoner should say the truth, otherwise, he deserves punishment of up to seventy-four lashes. This could be repeated until the truth was told, and each time, the guard could simply declare that the detainee was lying again. ${ }^{516}$ Torture during the interrogation of detainees cannot be justified by Tazir at all. This justification is against even Iranian penal law, and is nothing but an abuse of Islamic terms, especially, when prisoners are beaten collectively.

\section{Section 7.2: Does Iranian Law maintain enough safeguards to prevent torture?}

A review of the Iranian legal texts reveals that, even if we assume that corporal punishments are justifiable as lawful sanctions, these texts are unable to protect detainees and prisoners from being tortured, and the right to protection against torture can be violated quite easily. I will illustrate some of the problems with current Iranian legal texts in comparison with international standards:

1- Torture is not recognized as a very serious crime in Iranian laws. It must be a crime resulting in serious punishment, with the possibility to be proved by the victim, regarding

\footnotetext{
513 Supra note 247.

514 See: Reza Afshari, supra note 48, at 49.

${ }^{515}$ For examplw see: Habibollah Davaran \& Farhad Behbahani, supra note 349 at $104-106$.

${ }^{516}$ Reza Afshari, supra note 48, at 49.
} 
his unique situation. It is very difficult for victims to provide evidence of such practices, especially with regard to psychological torture. ${ }^{517}$

2- There is no serious mechanism for supervising places of detention and imprisonment.

3- Some non-judicial bodies such as the Revolutionary Corps hold their own custodies. ${ }^{518}$

4- Current legal texts cannot give sufficient guarantees that all prisons and custodies are controlled by the judiciary.

5- There is no recognition of the prisoners' and detainees' right to medical services, which can diminish the use of torture.

6- The right to legal assistance is not fully accepted. Accompaniment of a lawyer, and having access to medical services and other judicial officials and judges, may prevent the scope of torture used. ${ }^{519}$

7- The right to be in touch with one's family is not mentioned in Iranian legal texts, while it is considered an important safeguard in international documents. ${ }^{520}$

8- Lack of a clear definition of torture allows torturers to justify torture.

9- Lack of a specific procedure for hearing cases about torture leads to the possibility of justification through alleged Islamic notions.

10- Despite the Constitutional laws, Iranian parliamentary laws did not clearly invalidate confessions and testimonies based on torture.

11- There is no legal text about compensating for damages inflicted on a victim.

12- There is no text about training police and other law enforcement agencies to protect detainees from being tortured.

As I will discuss later, reformists put their fingers on these weak points and tabled some bills to bring the rules closer to international law specifications. ${ }^{521}$

\footnotetext{
${ }^{517}$ See: Interview with Bahman Keshavarz about new bill on torture, ISNA news agency, Sep. 12, 2003, online, Gooya website: http://news.gooya.com/2003/09/12/1209-p-22-php

${ }^{518}$ Tehran MP Criticizing Revolutionary Guard and the Judiciary, the speech of Fatemeh Haghighatjoo in Iran's Parliament, Khaneh Mellat Daily (Parliament Boultin) Saturday Nov. 12, 2003. Online; Parliament website: http://mellat.majlis.ir/archive/1382/08/18/notghha.htm\#5; also see: Situation of human rights in the Islamic Republic of Iran, supra note 425.

${ }^{519}$ Supra note 517.

${ }^{520}$ For example see: Article 37 of Standard Minimum Rules for the Treatment of Prisoners, supra note 116.

${ }^{521}$ See below: section 8.1 .
} 


\section{Chapter 8: Recent efforts to eradicate torture in Iran}

Officially, the practice of torture is denied in Iran; to speak about it is taboo. It was only after reformists came to power that some reformist newspapers started to address the issue. The press released information about life inside prisons, and criticized violations of the right to be protected against torture. ${ }^{522}$ They brought the reality of prisons and the weakness of legal texts into the public eye, and demanded better safeguards against torture. ${ }^{523}$ However, by playing such a role, reformist journalists became the new victims of torture - many were arrested and sentenced to jail. Some of them even showed up on $\mathrm{TV}$, confessing to espionage and other national security crimes. ${ }^{524}$ It seemed that the cycle began again.

Today, journalists are not the only group working to protect human rights. Reformist MPs, NGOs, and international organizations have also been serious in their campaigns for protection against torture.

People expected appropriate reactions to the situation from the reformists because President Khatami, as the head of the reformists, promised to support the rule of law and peoples' rights, among other goals. ${ }^{525}$ Responding to public demand for serious actions to stop torture, reformists had to fight to put an end to torture practically. The reformist MPs tabled several bills, which were approved by the parliament, but none of these bills found the opportunity to come to force as law. I will discuss these proposed bills and their fates.

Before discussing the most important attempts that took place in recent years, the Iranian legislative system is reviewed to give a better sense of what is going on in Iran and what are the barriers that stood in the way of eradicating torture.

\footnotetext{
${ }^{522}$ For example see: we are against torture, even torturing ex-torturers is not acceptable, by Farhad Behbahani, Asre Azadegan Daily, March 29, 2000.

${ }^{523}$ For example see: supra note 471.

${ }^{524}$ See: Theo Van Boven, supra note 436, paras 678-699.

${ }^{525}$ See: Maurice Copithorne, Report of the special representative of the Commission of Human Rights on the situation of human rights in the Islamic Republic of Iran, UNJAOR, $54^{\text {th }}$ Sess, UN Doc 4/1999/32, (1999) at 1.
} 


\section{Section 8.1: Iranian legislative system in a glance}

The Iranian legislative power contains three institutions currently; a parliament of 290 Members of Parliament (MPs), ${ }^{526}$ the Guardian Council of the Constitution (GC), ${ }^{527}$ and the Expediency Council (EC). ${ }^{528}$ Parliament may debate and approve motions tabled by the executive power upon the Cabinet's approval, as well as bills tabled by at least 15 MPs. ${ }^{529}$ Motions and bills passed by the parliament do not automatically become law. The GC is in effect like an Upper House of Parliament with the power to veto the Parliament's approvals. It is assigned to check the approvals, compare them with the provisions of the Islamic jurisprudence and the Constitution, and ratify them or return them to the Parliament for being modified. The council has 12 members; six members are Islamic clerics, and six others are civilian jurists. The leader appoints the first group of six, and the second is elected by Parliament among candidates nominated by the head of the judiciary who, himself, is appointed by the leader. ${ }^{530}$ According to article 93 of the Constitution, Parliament has no legal status if the GC has not been formed, except for the purpose of approving the credentials of the MPs and the election of six jurists to the GC. Given the compatibility of the legislation with Islamic provisions, only the opinion of the majority of the six clerics is valid, but regarding the Constitution, the opinion of the majority of all members will hold. ${ }^{531}$ Interpretation of the Constitution, and supervision over Parliamentary and presidential elections, are among other GC mandates. ${ }^{532}$

The role of the EC is to cut the debate between Parliament and the $\mathrm{GC}$ in hard cases. If Parliament refuses to modify its approval according to the GC's advice, the legislation would be sent to the EC by Parliament to be finalized one way or another according to the expediency of the Islamic regime. ${ }^{533}$. The leader is solely responsible for appointing all

\footnotetext{
${ }^{526}$ Article 64, Constitution of the Islamic Republic of Iran, supra note 469.

${ }^{527}$ Article 94, Constitution of the Islamic Republic of Iran, supra note 469.

${ }^{528}$ Article 112, Constitution of the Islamic Republic of Iran, supra note 469.

${ }^{529}$ Article 74, Constitution of the Islamic Republic of Iran, supra note 469.

${ }^{530}$ Articles 91, Constitution of the Islamic Republic of Iran, supra note 469.

${ }^{531}$ Article 94, Constitution of the Islamic Republic of Iran, supra note 469.

${ }^{532}$ Human Rights Watch, Iran Power versus Choice: Human Rights and Parliamentary Elections in the Islamic Republic of Iran, Vol. 8, No. 1 (E), March 1996. online (HRW website): www.hrw.org/reports/1996/Iran.htm

${ }^{533}$ Article 112, Constitution of the Islamic Republic of Iran, supra note 469.
} 
members of the EC, following no specific guidelines. ${ }^{534}$

Currently, all members of the $\mathrm{GC}$, and the absolute majority of the $\mathrm{EC}$, are hardliners appointed by the leader to confront the reform process in Iran led by President Khatami.

\section{Section 8.2: Reformist MP's Efforts in the Sixth Parliament}

Reformist MPs have put to use numerous methods to bring the question of torture to the public's attention, both inside and outside Iran. They regularly give speeches as a part of their mandate, and sometimes put their finger on the question of torture in Iranian prisons. They also have revealed the identity of torturers. For example, Fatemeh Haghighatjoo, a brave reformist, and one of the few female MPs, in her speech during the public session of Parliament, revealed additional information with regard to torture. She stated that in recent years, the Islamic Revolutionary Guards, a military organization in Iran, has had a role in arresting and torturing students and National-Religious Group members. They have been responsible for the arbitrary arrests of students, for the torture of students, and their forced confessions on TV. They never expected that students would later deny the validity of these confessions extracted under torture. ${ }^{535}$ As a member of the Parliament Committee to Visit Prisons and Custodies, Haghighatjoo revealed that members of this Committee have never been allowed to visit custodies of the feared Islamic Revolutionary Guards. ${ }^{536}$

Her words have brought about a heated debate. The judiciary prosecuted her and found her guilty of insulting the judiciary and spreading lies. ${ }^{537}$ She and many of other reformist MPs along with some 2500 other reformist candidates were disqualified by the GC, and were banned from running in the parliamentary election in February $2004 .^{538}$

\footnotetext{
${ }^{534}$ Article 110, Constitution of the Islamic Republic of Iran, supra note 469.

${ }^{535}$ Tehran Mp Criticizing Revolutionary Guard and the Judiciary, the speech of Fatemeh Haghighat joo in Iran's Parliament, Khaneh Mellat Daily (Parliament Boultin) Saturday Nov. 12, 2003. Online; Parliament website: http://mellat.majlis.ir/archive/1382/08/18/notghha.htm\#5 . Maurice Copithorne in his Report on the situation of human rights in the Islamic Republic of Iran addressed this subject, see: Maurice Danby Copithorne, supra note 422, para 1.

${ }^{536}$ Haghighat Joo, Ibid.

${ }^{537}$ Iran: Parliamentarian Convicted, Human Rights Watch News, Jan. 4, 2002. Online; HRW website: www.hrw.org/press/2002/01/iran0104.htm

${ }^{538}$ for more information see: Analysis: End of an era of reform?, By Jim Muir, BBC News, Thursday, 19 February, 2004, Online(BBC website): http://news.bbc.co.uk/1/hi/world/middle east/3505049.stm
} 
Next I examine some of the most important bills tabled by reformist MPs. Unfortunately, by the end of the reformist Parliament, none of these bills had passed the GC to come into force as law. Further, there is no hope that the new Parliament, made up of conservative MPs who were not elected in a free election, has any desire to follow the campaign against torture.

\section{Sub-section 8.2.1: Bill of implementation of article 38 of the Constitution}

Some lawyers believe that being a party to the ICCPR, Iran does not need to create more laws to stop torture. Their view is: We have enough legal texts, but as long as our prosecutors count on torture as an instrument to complete their investigations, it is impossible to eradicate the use of torture in Iran. ${ }^{539}$ These lawyers actually point to a systematic problem in the Iranian judicial system. It is that rooted in a dominant totalitarian, non-democratic view in the judiciary that ignores peoples' rights. ${ }^{540}$

The reality is that Iran's regulations for protecting people against torture and supporting victims of torture are weak. Realizing such a weakness, on the one hand, and receiving many reports on the use of torture and the lack of a supervising body to control the situation in Iran's prisons on the other hand, forced reformist MPs to provide clearer laws. $^{541}$

In the first step, given the reality of the absolute ban on torture in Article 38 of the Iranian Constitution, 175 members of Parliament tabled a bill to enforce that article in legal texts, with more safeguards to achieve its goal. ${ }^{542}$ This bill evades the problem of establishing a concise definition of torture by enumerating acts to be contemplated as torture. There are:

1 Any kind of physical abuse in order to make the detainee confess;

2 Holding the prisoner in solitary confinement, or keeping more than one prisoner in a cell;

\footnotetext{
${ }^{539}$ Mahmood Akhondi, Comments on the bill of Banning Torture, Nowrooz Daily, Jan. 31, 2001 at 8. ${ }^{540}$ Ibid.

${ }^{541}$ An Interview with Naser Ghavami, the head of judicial committee of Parliament, supra note 255.

${ }^{542}$ Implementation of Article 38 Bill, Laws Department of the Parliament Bulletin, $6^{\text {th }}$ duration, $2^{\text {nd }}$ year, No. 385, Dec. 10, 2001; online: Parliament Website; www.mellat.majlis.ir/tarhha20\%va20\%lavayeh.htm/301-400/385.htm
} 
3 Blind folding inmates;

4 Interrogation while the prisoner is blind folded;

5 Interrogation late at night;

6 Keeping the inmate awake;

7 Insulting and degrading inmates during the interrogation process and putting them under physical pressures;

8 Interrogation while he or she is facing the wall;

9 Using drugs to make the detainee lose control of his mind and senses;

10 Depriving inmates from health services;

11 Broadcasting or playing loud music in order to put inmates under psychological pressure;

12 Holding inmates in very crowded and noisy places;

13 Keeping inmates thirsty or hungry, and violating sanitation standards or depriving them of sanitation;

14 Mixing prisoners and keeping different types of prisoners together without any classification;

15 Preventing inmates from the right to daily fresh air;

16 Preventing them access to books and newspapers;

17 Denying the prisoners' right to meet their families weekly, or contact them by phone;

18 Putting inmates under psychological pressure by intimidating their families;

19 Denying the prisoner's right to visit his lawyer;

20 Denying the prisoner's right to practice his religion;

21 Asking questions non-related to the official accusations during the interrogation.

It so happens that these enumerated acts were all in use in Iranian places of detention and imprisonment, and reformists were seeking to change the current situation. The idea of describing specific types of torture was supported by the Tehran Bar Association. Bahman Keshavarz, the head of the Bar, believed that some of these items mentioned in the bill indeed qualify as torture, even though Iranian courts do not consider them as such. For example, playing loud music may not be treated as torture under existing Iranian 
laws. Therefore, it is quite useful to name all possible kinds of torture, and actions that may lead to the practice of torture. ${ }^{543}$

There are some other important observations oo the content of the mentioned bill:

1 While the bill does not give a general definition of torture, but only mentions samples of varying types of torture, the drafters of the bill attempted to illustrate all possible forms of torture that have been used in Iran. But one cannot say that it is impossible to imagine other new methods of torture. Professional torturers have the means to find new ways of inflicting pain on their victims.

2 Section 1, note 2 provides an exception to the concept of torture while it says: "Flogging after trial, according to the courts' sentences and after being confirmed by appeal courts, is not covered by the definition in this section". It is very strange that they talk about definition of torture while they never give any definition. This part of section 1 deals with flogging as punishment in Islamic law. It illustrates the difference between the definitions of torture in international law and in Islamic law. This bill does not argue other corporal punishments which are internationally controversial such as retaliation (Qisas), amputation (Qata) and stoning (Rajm).

3 Section 2 makes some exceptions to the ban on night-time interrogation as it is defined in section 1. In these exceptional conditions, detainees may be interrogated during the night for a maximum of one week, and he or she can be kept incommunicado for a period of up to fifteen days. These specific conditions are: a) when there is a necessity to reveal a possible future crime, knowing that the detainee might have useful information about it; b) if the crime is about a drug-dealing network, robbery and armed crimes; military actions against the country, and espionage in favor of foreigners. Therefore, ordering to interrogate during the night and keeping the detainee incommunicado needs to have sufficient legal justification. Renewing an order to keep the detainee incommunicado is possible for only 15 more days, and is subject to endorsement by the appeal court. This part of the bill is problematic. If something is defined as torture, how can it

${ }^{543}$ Interview with Bahman Keshavarz about new bill on torture, supra note 517. 
be allowed under certain circumstances? And who decides when a crime potentially deals with something as vague and cryptic as military operations or espionage?

4 Section 4 of the bill contains a very crucial guarantee to prevent torture. It stipulates that every record of interrogation should contain at least the following information; a) the place of interrogation; b) the start and end times of the interrogation session; c) the name of the interrogator or interrogators and their autographs; d) the detainee's signature. If these records fail to have all these features, or are completed only after, the interrogation would be invalid.

5 Section 5 provides another guarantee stating that all information and confessions which are exerted without respecting this law are invalid, refused and unacceptable to be invoked against the accused. If a detainee announces that all or part of his confession was obtained through violation of this law, a new interrogation will be performed in the court, in the presence of the judge and the detainee's lawyer.

6 Section 6 says that the place of detention or imprisoning of an inmate must be mentioned in the judicial order or sentence; moreover, the inmate, his lawyer, and his family must be informed about the place of detention.

7 According to section 7, if the judge decides that it is necessary to record the interrogation session on audio or video tape, the detainee should be informed of this. All tapes are part of the inmate's file and must be protected as such. A copy of these tapes must be given to the detainee or his lawyer on request.

8 A supervisory committee was established according to section 9 of the bill. This committee's main mandate is to supervise treatment of detainees and prisoners, and to make sure that judicial agents respect the content of this law. This committee composed of three persons who represent the judiciary, three MPs, and three persons who are introduced by the executive power. Members of this committee, collectively or individually, are entitled to visit all places of detention and imprisonment all over the country, at any time. If they are informed about the practice of torture, they should report it to the heads of powers (judiciary, 
legislative and executive). A copy of the report is to be filed in the appropriate court to punish the accused agents. Courts should hear the case immediately and report the result to the committee and heads of powers. Members of the committee cannot be prosecuted or arrested for performing their legal duties.

9 Section 11 of the bill is about punishment for committing the crime of torture. Agents who commit torture may be sentenced to jail for 1-3 years, in addition to a suspension from their job for 5 years, if they commit the crime for the first time. Punishments are more severe for further incidences of abuse. According to this section, those who order torture, and agents who are informed about torture, but hesitate to report it, as well as agents who are not fully cooperating with the committee, may be punished. Persons convicted according to this section are not eligible to be granted amnesty.

10 Section 12 of the bill says that immediate and public trials must be provided in cases related to the crime of torture.

The bill was approved by the Parliament in March 2002, and was sent to the GC as a part of the legislative process.

Hardliners, who now hold the majority of power, including control over the judiciary power, though they hold only a very small minority of popular support, condemned this bill, claiming that it is politically motivated. Reformists deny any political purposes and say that it is useful for ameliorating Iran's position in the world and protecting human rights in Iran. In addition, Iranians deserve to have a better position in the world. ${ }^{544}$

Given the fact that the Guardian Council is acting to stop reform in Iran, there was a high possibility that the GC would reject this bill and find it in opposition to Islamic rules, MPs decided to bring the bill to public attention and provide a kind of public opinion pressure on the GC. The heads of the three Committees of Parliament, namely, the National Security Committee, the Foreign Affairs Committee, and the Judicial Affairs Committee, asked two of the high-ranking clergy members, Ayatollah Sanei and Ayatollah Ardebili, to give their comments on the bill's content. These clergymen

${ }^{544}$ Interview with Meisam Saeedi,an MP from Tehran, , ISNA news agency, July. 23, 2003, News no. 820500515. online, ISNA website: http://www.isna.ir/news/newsprint.asp?ip=260129 
responded to the bill, stating that it is not in opposition to Islam. ${ }^{545}$ These comments could make it more difficult for the $\mathrm{GC}$ to reject the bill with the claim that it is against Islamic teachings.

Despite this opinion of the clergymen, the GC vetoed the passed bill on the ground that it was incompatible with Islam, and sent it back to the Parliament for modification. They argued that the bill would limit the authority of judges to adjudicate on the admissibility of the confessions and therefore ruled that the bill was against the principles of Islam. ${ }^{546}$ They added unofficially that this law might prevent Islamic corporal punishments such as flogging and execution. ${ }^{547}$

MPs insisted on their position and after doing some minor changes, which were not what the GC was looking for, sent the bill back to the $\mathrm{GC}$, who again rejected the bill. This game of to and fro happened four times. The GC asked parliament to add the following section to the bill: "Judges' orders which are delivered according to the law are exempted". ${ }^{548}$ This made it clear that hardliners were actually seeking to leave a hole in the law that would make possible the practice of torture. Reformist MPs could not accept such a proposal, firstly, because judges may then order torture, although it is against the Constitution and the most basic notion of human rights. Secondly, the GC does not have the right to suggest any such phrase or section. They can only admit or reject the Parliament's approvals according to clear reasons. ${ }^{549}$

A Report of the international NGO Human Rights Watch (HRW) condemned the rejection of the bill by the $\mathrm{GC}$, stating that the GC disregards the clear prohibition in Iranian and international law of the use of torture to obtain confession. In addition, the GC permits judges to admit confession as evidence even when it is clear that it is

\footnotetext{
${ }^{545}$ Sanei and Ardebili: Bill on Banning Torture is not against Islam, Norooz Daily, No. 300, April. 1, 2002 at 1 .

${ }^{546}$ Special Rapporteur on the question of torture misunderstood the reason expressed by the GC. See: supra note 436 , para 679.

${ }^{547}$ Supra note 255.

${ }^{548}$ Commission Continues Revsing The Bill To Join UN Convention Against Torture, Khaneh Mellat (Parliament) Daily, Tuesday, Oct. 28, 2003, online; parliament website: www.mellat.majlis.ir/commissions $20 \%$ news.htm/gazaayee/1382.htm

${ }^{549}$ Supra note 255.
} 
extracted under torture. ${ }^{550}$ The HRW Report also criticized the bill itself, as it would not have provided sufficient safeguards against torture, and it fell far short of Iran's international obligations. HRW criticized that a detainee may be held incommunicado and the exemption of certain groups of suspects from the safeguards contained in the bill. ${ }^{551}$ In addition, UN Special Rapporteur Mr. Theo Van Boven also criticized the bill in his 2003 Report because certain categories of suspects were exempted from the safeguards contained in the bill. ${ }^{552}$

I agree with HRW and the Special Rapporteur about the weak points in the bill, but I think the MPs tried to achieve a bottom line regarding the barriers in their way. It was quite predictable that clerics in the $\mathrm{GC}$ who are benefiting from the use of torture to suppress their opposition would not let the bill pass easily. I am sure that MPs are aware of such problems. At this stage, they only thought about a possible practical shortcut to limit the scope of using torture.

Armin, a reformist MP, during a protest speech in parliament, criticized the $\mathrm{GC}$ for insisting on the rejection of the bill. He said that the GC's rejection of the bill, and their suggestions and proposals to add new items to the bill, were just attempts to legalize torture at Parliament's cost. If the reformist MPs came to agree with them, that would be an unforgivable black point in their careers. ${ }^{553}$

Finally, Parliament, in a public session on November 12, 2003, approved to send the bill to the Expediency Council, another body controlled by hardliners, according to article 112 of the Constitution. Parliament's judicial committee announced that Parliament could not change the content of the bill according to the GC's comments. As a result, the bill was sent to the EC for a final decision. ${ }^{554}$ At the time of this writing, the EC has not yet assessed the bill, and it seems unlikely that news about it will be heard soon. The EC has

\footnotetext{
${ }^{550}$ Iran: Veto on Torture Bill Condemned, HRW News, New York, June 12, 2002, online, HRW website: www.hrw.org/press/2002/06/iran0612.htm

${ }^{551}$ Ibid.

${ }^{552}$ Theo Van Boven, supra note 436, para 678.

${ }^{553}$ GC vetoed the bill against torture again, BBC Persian News, Mon. Sep. 9, 2003, online, BBC Website: www.bbc.co.uk/persian/iran/030909 mf_torture.shtml\#top

${ }^{554}$ The bill against torture sent to Expediency Council, Khaneh Mellat (Parliament) Daily, Wednesday, Nov. 12, 2003, online; parliament website: www.mellat.majlis.ir/archives/1382/08/21/parlemanttoday.htm\#7
} 
a poor record of upholding critical laws, and a tendency to help hardliners by using a time consuming strategy.

\section{Sub-section 8.2.2: Bill to join the UN Convention Against Torture}

Reformist MPs did not give up after they failed to convince the GC to pass the Bill of Implementation of Article 38. They took further action after receiving advice from the members of the Tehran Bar Association. ${ }^{555}$ They tabled another bill, the Bill to Join the Convention Against Torture and Other Cruel, Inhuman or Degrading Treatment or Punishment, ${ }^{556}$ on July 23, 2003. This bill contains only one article, authorizing the Iranian government to sign and ratify the convention that consists of a preamble and 33 articles.

During the discussion period, some conservative MPs criticized the new bill, employing the following arguments:

- It is against Islam;

- Regarding the content of the Convention, adopting it would be against article 3 of the Constitution, which stipulates the necessity of adopting laws according to the Islamic teachings;

- Approving such a law and adopting the Convention is not necessary while there are sufficient legal texts to achieve the goal of fighting torture. The Constitution and Parliamentary laws in Iran already banned and criminalized torture strongly;

- It provides more excuses for foreigners to interfere in the internal affairs of Iran. $^{557}$

Reformist MPs responded stating that the bill did not conflict with Islamic teachings, because Iran can join the Convention with the reservation to respect Islamic laws. For the purpose of legitimacy in the eyes of other countries, it is very important to be party to the

\footnotetext{
${ }^{555}$ Interview with Bahman Keshavarz about new bill on torture, supra note 517.

${ }^{556}$ Bill to Join Convention against Torture and Other Cruel, Inhuman or Degrading Treatment or Punishment, Laws Department of the Parliament Bulletin, $6^{\text {th }}$ duration, $3^{\text {nd }}$ year, No. 603, July. 23, 2003; online: Parliament Website; www.mellat.majlis.ir/tarhha20\%va20\%lavayeh.htm/601-700/603.htm ${ }^{557}$ See the comments of Sobhani and Qurbani, two conservative MPs on the bill: Parliament allows Government to Join The UN Convention Against Torture, ISNA News Agency, July 23, 2003, News No. 8205-00137, online, ISNA website: http://www.isna.ir/news/NewsCont.asp?id=259751\&lang=P
} 
Convention, which helps to uphold human rights standards in both the domestic and international context. Being party to the Convention allows a better position in the world, and would help to counteract many of the accusations against Iran of the violation of human rights. 558

The bill was approved in Parliament on July 23, 2003 and was sent to the GC to be confirmed as compatible with Islam and to the Iranian Constitution. The GC rejected the Parliament's approval on August 12, 2003, reasoning that parliament should have to provide financial resources for the implementation of this law. ${ }^{559}$ This decision was based on Article 75 of the Constitution that states that Parliament may not increase public expenditure, or decrease public income, by approving laws based on bills tabled by MPs. It is interesting that at this stage they did not address any Islamic-based reasoning to oppose the bill, while all the unofficial comments of hardliners showed attempts to reject it from an Islamic perspective.

In response to this critique, the MPs provided a source for financing the implementation of the law. Despite this, the bill was refused again by the GC for not being in accordance with Islamic rules and sent back to the Parliament for revising. The reformist Parliament in the last week of its life (May 2004) sent the bill to EC according to Article 112 with no revision. $^{560}$

Some lawyers are of the opinion that even if the bill will be approved by the EC, there is no evidence that Iran will uphold its regulations. Regardless of section 9 of the Civil Code, Iranian courts are still not taking into consideration international binding conventions and agreements as law. ${ }^{561}$ Their resistance against these international agreements is politically motivated or based on ideological concerns.

\footnotetext{
${ }^{558}$ Joining the Convention is necessary, ISNA News Agency, July 23, 2003, News No. 8205-00515, online, ISNA website: $\underline{\mathrm{http}} \mathrm{:} / \mathrm{www}$.isna.ir/news/NewsCont.asp?id=260129\&lang=P

${ }^{559}$ Commission Continues Revising The Bill To Join UN Convention Against Torture, Khaneh Mellat (Parliament) Daily, Tuesday, Oct. 28, 2003, online; parliament website: www.mellat.majlis.ir/commissions $20 \%$ news.htm/gazaayee/1382.htm ${ }^{560}$ last steps of the reformist parliament for human rights, Vaghayeh Etefaghieh Daily, Monday, May 25, 2004.

561: "Comments on Bill to Join Iran to the UN Convention Against Torture" legal studies bureau of the parliament research center, khaneh Mellat daily, Monday Aug. 7, 2003. online: http://mellat.majlis.ir/archive/1382/researchcenter/hoghooghi/news1.htm.
} 


\section{Sub-section 8.2.3: Bill to protect the rights of Accused or Convicted People}

In another attempt to help potential victims of torture, especially due to the existence of unknown custodies, reformist MPs tabled a new urgent bill called the "Bill to Protect the Rights of Accused or Convicted People." 562 This text was presented first on November 3 , 2003. It was under discussion in the legal and judicial affairs committee of the reformist Parliament. ${ }^{563}$ I do not think that it will be passed by the conservative parliament.

Despite the fact that this bill does not point to the question of torture directly, there are some safeguards, which can prevent the use of torture against detainees, such as ${ }^{564}$ :

1 An independent judge called a "Judge of Detaining and Releasing", with at least ten years judicial experience, will be put in place to supervise all detaining orders during the investigation process;

2 All detained persons must be informed of their right to legal assistance, the right to silence, and the right to know about the location of their custody;

3 All custodies are to be under the supervision of the judiciary, or its affiliated bodies;

4 All detainees must be granted access to medical services, even outside of custody, if necessary.

The bill was tabled with the aim of taking a step towards meeting international standards according to international legal documents that Iran is a party to. The right to fair trial, the right to silence, the right to a translator during the interrogation, the right to compensation in the case of judicial errors and the right to education are among other rights supported in this bill. ${ }^{565}$

\footnotetext{
${ }^{562}$ Bill To Protect The Rights Of Accused Or Convicted People, Laws Department of the Parliament Bulletin, $6^{\text {th }}$ duration, $3^{\text {rd }}$ year, No. 700, 2003; online: Parliament Website; www.mellat.majlis.ir/tarhha20\%va20\%lavayeh.htm/601-700/700.htm

${ }^{563}$ Bill to Protect The Rights of Accused or Convicted People to be discussed in Judicial Committee, Khaneh Mellat (Parliament) Daily, Saturday Oct. 25, 2003, online; parliament website: www.mellat.majlis.ir/commissions $20 \%$ news.htm/gazaayee/1382.htm

${ }^{564}$ Report on bill to protect the rights of accused or convicted persons, legal studies bureau of parliament research center, Khaneh Mellat (Parliament) Daily, Mon. Nov. 17, 2003, online; parliament website: www.mellat.majlis.ir/archives/1382/researchcenter/hoghooghi/newsl.htm ${ }^{565}$ Ibid.
} 


\section{Chapter 9: Conclusion}

Today, torture is seen as a crime against humanity, even though it continues to be used for various purposes in many parts of the world. It is a reality that in almost every part of the world torture has been used at some point, regardless of any and all attempts to stop it. The history of major ancient civilizations such as Persia, Rome, China and Egypt, is replete with stories of the torture endured by detainees and prisoners. These stories are very similar to each other in many respects. Campaigns against torture are as old as torture itself.

Usually, torture is driven by states, most commonly, totalitarian states, and it is among the crimes they commit against their nationals. Today, international law propounds that the use of torture is against the values of human societies. Even torturers may ask their masters about the legitimacy of torture. Unfortunately, based on reports provided by Special Rapporteurs on the question of torture, in spite of the official denial of states, torture is vastly used in the world.

Torture is a crime against humanity not only under international law. Most human rights documents, at both regional and international levels, address the issue of torture and illtreatment of persons. ${ }^{566}$ While they may not agree on a definition for torture, they declare that there is a total prohibition on torture, prohibited even during emergencies or armed conflicts. These documents insist that torture is impermissible. ${ }^{567}$ The dedication of international human rights law to outlawing such acts is also evidenced by the existence of instruments dedicated to the prevention of torture ${ }^{568}$ Further, the United Nations and some other important regional institutes have also some specialized bodies responsible for the prevention of torture.

The definition of Torture and other cruel, inhuman or degrading treatment and

${ }_{566}$ e.g.: Article 7 of the Covenant on civil and political rights (ICCPR), 19 December 1966; Article 37(a) of the Convention on the rights of the child (CRC), 20 November 1989; Article 5(2) of the American Convention on human rights (ACHR), 22 November 1969; Article 3 of the (European) Convention for the protection of human rights and fundamental freedoms (ECHR), 4 November 1950; Article 5 of the African Charter on human and peoples' rights, 26 June 1981.

${ }^{567}$ Article 4(2) CCPR, Article 15(2) ECHR, Article 27(2) ACHR.

${ }^{568}$ European Convention for the prevention of torture and inhuman or degrading treatment or punishment, supra note 69; Inter-American Convention to prevent and punish torture, supra note 69. 
punishment, as offered in modern international law are facing some challenges. One of the most important challenges is made by Islamic states with regard to the Islamic corporal punishments. They believe that these punishments are derived from the God's will; this is reflected in domestic laws as lawful sanctions. Such a justification is refused by the human rights activists and international organizations, reasoning that the definition of lawful sanctions cannot cover corporal punishment.

In this paper, Islamic law was discussed. It was submitted that, firstly, even in traditional Islamic law, it is possible not to practice corporal punishments in certain conditions. Secondly, there are some other readings of Islam versus the traditional view which allow us to interpret Islamic controversial issues in favor of a human rights position, accepting human rights rules, as the outcome of human experience and the growth of humanity over time is closer to justice and the true spirit of Islam. Thirdly, the truth is that Islamic notions in some countries are being applied simply to justify torture in general, while in most of the cases those practices are, in reality, not in compatible with Islamic rules.

Iran, as an Islamic state, was herein examined. We discussed the history of torture and laws and regulations in this regard. Torture is banned in Iranian law; however, there is no specific definition of torture under Iranian law. Regarding the nature of the Iranian law, which claims to be Islamic, corporal punishment is accepted. But the scope of practicing torture is not limited to corporal punishments. In practice a number of politicians, journalists, and students are victims of torture. Practicing torture in order to obtain confession or information is justified by Tazir. We discussed that regardless of the fact that Tazir as a corporal punishment is not acceptable, torturing prisoners does not fall within the definition of Tazir. Tazir is a punishment and based on Islamic law can be applied only after trial by a competent court.

The current situation in Iran was then presented, based on reports provided by UN Special Representatives, Mr Galindo Pohl and Mr. Maurice Copithorne, as well as the reports provided by the Special Rapporteurs on the question of torture, Amnesty International and Human Rights Watch. We also considered available ex-prisoners' memoirs to give a tangible picture of the situation in Iran.

Some positive steps made by reformists after 1997 were next explored. Reformist MPs 
have put to use numerous methods to bring the question of torture to the public's attention, both inside and outside of Iran. They provided some bills to provide more safeguards against torture but all their attempts have been failed due conservative GC resistance to pass them.

Hardliners, who are holding the majority of power in Iran, are supporting torturers as they tried to hide the realities in the case of Zahra Kazemi, an Iranian-Canadian photo journalist who was tortured to death in Evin prison in June 2003. Hardliners stopped the process of reform in Iran by disqualifying more than 2500 reformist candidates and barring them from running in the election which took place in February 2004.

At present, there is no hope to see any positive changes - at least in near future. Despite the many attempts to eliminate the use of torture, in Iran, it remains active and jeopardizes many lives in Iranian prisons. 


\section{Bibliography}

\section{English books and articles:}

1- Edward Abrahimian, Tortured Confessions: Prisoners and Public Recantations in Modern Iran, $1^{\mathrm{ST}}$ ed. (Los Angeles: University of California Press, 1999)

2- $\quad$ Edward Abrahimian, Khomeinism: Essays On The Islamic Republic, (Los Angeles: University of California Press, 1993).

3- Nagan, Winston \& Atkins, Luice "The International Law of Torture: From Universal Proscription to Effective Application and Enforcement" (2001) 14 Harv. Hum. Rts. J.87.

4- $\quad$ L. A. Parry, The History of Torture In England, $2^{\text {nd }}$ ed.(Montclair: Patterson Smith, 1975)

5- Lea, Henry Charles, Torture, $1^{\text {st }}$ ed.(Philadelphia: university of Pensylvania Press, 1973)

6- $\quad$ Cesare Beccaria, On Crimes And Punishments, $1^{\text {st }}$ ed. (Indianapolis: Hackett Publishing Company, 1986)

7- Herbert C. Kelman, "The Social Context of Torture: Policy Process and Authority Structure" in Ronald D. Crelinsten \& Alex P. Schmid, ed. The Politics of Pain, Torturers and Their Masters (Oxford: West view Press, 1995)

8- Ronald D. Crelinsten \& Alex P. Schmid, "Introduction: The Politics of Pain" in Ronald D. Crelinsten \& Alex P. Schmid, ed. The Politics Of Pain, Torturers And Their Masters (Oxford: Westview Press, 1995)

9- $\quad$ Ingelse, Chris, The UN Committee Against Torture: An Assessment, $1^{\text {st }}$ ed. (London, Boston \& The Hague: Kluwer Law International, 2001)

10- Ann-Marie Bolin Pennegard, "Article 5", The Universal Declaration of Human Rights: A Common Standard of Achievement, ed. Asbojø̈rn Eide \& Gudmundur Alfredsson (London: Martinus Nijhoff Publishers, 1999)

11- Reza Afshari, Human Rights in Iran: the abuse of cultural relativism, (Philadelphia: University of Pennsylvania Press, 2001) at 48; also see supra note 357.

12- Wolfgang S. Heinz "The Military, Torture and Human Rights" in Ronald D. Crelinsten \& Alex P. Schmid, ed. The Politics Of Pain, Torturers And Their Masters (Oxford: Westview Press, 1995)

13- Cathrine M. Grosso, "International Law in the Domestic Arena: the case of torture in Israel" (2000) 87 Iowa L. Rev. 305

14- Roberts and R. Guelf, Documents on the Laws of War, 2nd ed., Clarendon Press, Oxford, 1989,

15- . Rupert Ticehurst, The Martens Clause and the Laws of Armed Conflict, in "International Review of the Red Cross", no 317, 30 March 1997, 125-134

16- C. Greenwood, "Historical Development and Legal Basis", in Dieter Fleck (ed.), The Handbook of Humanitarian Law in Armed Conflicts, (Oxford: Oxford University Press, 1995)

17- M. Cherif Bassiouni, "An appraisal of torture in international law and practice: The need for an International Convention for the prevention and suppression of torture", Revue internationale de droit pénal, Vol. 48, 1977, Nos. 3 and 4

18- Henry J. Steiner \& Philip Alston, International Human Rights in Context, 2 ed. (New York: Oxford University Press, 2000)

19- Hans Danelius, “Article 5" in The Universal Declaration of Human Rights: A Commentary, ed. Asbojǿrn Eide, Gudmundur Alfredsson and others (Norway: Scandinavian University Press, 1992) 
20- Hernan Reyes, Health and human rights in prisons, in "HIV in Prisons: A reader with particular relevance to the newly independent states", ed. World Health Organization-Europe "HIPP" (Health in Prisons Project), 2001

21- Walter Kälin/Larisa Gabriel, "Human rights in times of occupation: An introduction", in Human rights in times of occupation: The case of Kuwait, ed. Walter Kälin , (Bern, 1994)

22- $\quad$ Theodor Meron, Human rights in internal strife: Their international protection, (Cambridge: Cambridge university press, 1987)

23- Ahcene Boulesbaa, The UN Convention on Torture and the Prospects for Enforcement, (Martinus Nijhoff Publishers, 1999)

24- Herman Burgers \& Hans Danelius, The United Nations Convention Against Torture: A Handbook on the Convention Against Torture and other Cruel, Inhuman or Degrading Treatment or Punishment, (Martinus Nijhoff Publishers, 1988)

25- $\quad$ Faiza Patel King and Anne-Marie La Rosa, The Jurisprudence of the Yugoslavia Tribunal: 19941996, European Journal of International Law, Vol.8 (1997), No.1

26- walter Kalin, The struggle against torture, International Review of the Red Cross no 324, 30-091998, 433-444

27- $\quad$ Camille Giffard, The Torture Reporting Handbook, (Clochester: Human Rights Center, University of Essex, 2000)

28- $\quad$ Lene Wendland, A handbook on State Obligations under the UN Convention Against Torture, (Geneva: APT Publication, 2002)

29- $\quad$ Sandra Mackey, The Iranians, Persia, Islam and the Soul of a Nation, (New York: Penguin Group Publishing (Pulme Printing), 1998)

30- J. E. Knorzer, Ali Dashti's Prison Days Life Under Reza Shah, (Los Angeles: Mazda Press, 1994)

31- John Simpson, Life under Khomeini's Regime inside Iran, (New York: St. Martin's Press, 1988)

32- $\quad$ Robin Wright, In the Name of God: The Khomeini Decade, (New York: Simon \& Schuster, 1989)

\section{Persian books and articles:}

33- $\quad$ Ehsan Tabari, Torture and Hope, $1^{\text {st }}$ ed., (Tehran, 1957)

34- Ehsan Naraghi, "The Structure of SAVAK and Army during the Shah's Reign" an interview made by Morteza Rasouli for Iranian History studies Institution, March 1996

35- Hussein Mirmohammad Sadeghi, "Crimes Against Humanity", in Legal Ideas Review, faculty of Judicial Sciences and Administrative Judicial Services, Vol.9.

36- Parviz Sanei, Public Criminal Law, $4^{\text {th }}$ ed., vol.1, (Tehran: Ganje Danesh Publishing co., 1992)

37- Ziaoddin Peimani, Judicial Evidences in French Law after Revolution, (Tehran: Ganje Danesh Publishing, 1977)

38- Jalalodin Ghiasi, Comparative Studies in Penal Law, ${ }^{\text {st }}$ ed., Vol. 1, (Tehran: Hawzah and university Research Center Press, 2001)

39- Hassan Dadban, Public Criminal Law, $1^{\text {st }}$ ed., (Tehran: University of Tabatabaee Press, 1998)

40- $\quad$ Reza Mazlooman, Injustice Under Coverage of Law, in People's Right Magazine, No. 43, Year 11 (Tehran: 1975); and, Aboosaidi, Human Rights, $1^{\text {st }}$ ed. (Tehran: Asia Publications, 1965)

41- Mohammad Ali Ardebili, Public Criminal Law, $1^{\text {st }}$ ed., vol.1, (Tehran: Mizam Publishing, 2000) 
42- Mohammad Ali Ardebili, "Torture" in Legal Research Review, International Law studies Center, vol. 45, July 1999

43- Mohammad Jafar Pooyandeh, Universal Declaration of Human Rights and Its History, ed.1 (Tehran: Nei Publications, 1998)

44- Jalil Omidi, The Rights of Accused Person in the courts according to International and regional documents of Human Rights, Tehran Bar Assocoiation Review, New Series vol.2, Jan. 2001

45- Hussein Mehrpoor, Human Rights in international documents and the position of the Islamic Republic of Iran, (Tehran: Ettelaat Publications, 1995)

46- Bahman Aghaee, Human Rights Culture, ed. 1 (Tehran: Ganje Danesh Publishing, 1997)

47- Mohammad Ebrahim Shams Nateri, A Comparative Study on Capital Punishment, $1^{\text {st }}$ ed., (Qum: Islamic Propagation of the Qum Seminary Publications, 1999)

48- Reza Norbaha, Torture as it is defined in the Convention Against Torture, Tehran Justice Administration Collection, No. 149, Dec. 1989 at 4

49- Hussein Ali Montazeri, "Political Memoirs” (Los Angles: Ketab Corp, 2001)

50- Hussein Ali Montazeri, "Replying to the Questions About Tolerance and Violence" in Views, Aug. 6, 1999

51- Hussein Ali Montazeri, “Basis of Islamic Government in Islamic Jurisprudence”, Vol.3, $1^{\text {st }}$ ed., (Tehran: Tafakor Publishing, 1991)

52- Hussein Ali Montazeri, "Replying to the Questions of Prisoners' Families about Interrogation and Validity of Confessions exerted from Political Detainees under Torture" in Views, May. 12, 2001

53- Hussein Ali Montazeri, Resaleh Amalieh, available online (Montazeri website): http://www.montazeri.ws/Farsi/Resaleh/html/0020.htm\#0358

54- Mohsen Kadivar, Human Rights and Religious Intellectualism, Aftab Monthly, Vol. 28, August 2003

55- $\quad$ S. Esmail Rasoolzadeh, Imam Ali's Judgments, (Tehran: Dehghan Publishing, 1984)

56- Muhammad Shirazi, Rights of Prisoners According to IIslamic Teachings, $1^{\text {st }}$ ed. (London, 2002)

57- The Entire Negotiations During the Final Assessing of the Islamic Republic of Iran Constitution, Vol. 1, (Tehran: Parliament Publishing, 1981)

58- Reza Feiz, "Human Dignity in Ibn-Arabi's Irfan" in Report on the Seminar of Human Rights and Negotiations Among Civilizations" ed. Mofid University Administration, (Ghom: Mofid University Publishing, 2001)195-210

59- Mohamad Taghi Jafari Tabrizi, Research On two system of human Rights: Islamic and Western, (Tehran: Office of International Legal Services, 1991) at 100.

60- Habibollah Amoozgar, "Spiritual and Literal Koran Interpretations of Khajeh Abdollah Ansari" $7^{\text {th }}$ ed. (Tehran: Eghbal Publishing, 2000)

61- Mohammad Hussein Tabatabaee, “Al-Mizan in Koran Interepretation" Vol.13, $3^{\text {rd }}$ ed., (Beirut: Alami Publishing, 1989)

62- Abdollah Javadi Amoli, "Philosophy of Human Rights" $2^{\text {nd }}$ ed. (Qom, Iran: Asra Publishing, 1998)

63- Imam Ali Ben Abitalib, Nahj-ol-Balaghah, letter no. 53 (Letter to Malik Ashtar), Para 15-17

64- Emadoddin Baghi, Reports on Shia Jurisprudence Courses by Ayatollah Montazeri from Sep. 21, 2003 to Oct, 10, 2003

65- Emadodin Baghi, Contemporary Religious Ideas, (Tehran: Saraee Publishing, 2003) 
66- Naser Makarem Shirazi, Anvar-Al-Feghaha: Hodood \& Tazirat Book, Vol.1, $1^{\text {st }}$ ed., (Tehran: Imam Ali School Publishing, 1996)

67- Rohollh Khomeini, Islamic Jurisprudence(Tahrir-Al-Vasileh), translated into English by Laleh Bakhtiar, vol.1, (Tehran: Mabath Foundation Publishing, 1986)

68- Roohollah Khomeini, Sahifeh Noor, Vol.1, (Qum: Organization to protect and publish Imam Khomeini's works, 1990)

69- Sadegh Haghighat, "Realizing Time and Place in Ijtihad" in Ijtihad of Time and Place, Vol.2, (Qum: Organization to protect and publish Imam Khomeini's works, 1995) 37-88

70- Mostafa Mohaghegh Damad, "Religios Epistimology and Human Rights' Thought" in International Human Rights and Negotiations Among Civilizations Seminar Articles Collection" ed. Mofid University Administration, (Ghom: Mofid University Publishing, 2001) 285-294

71- Naser Ghorban Nia, "The Relation Between Justice and Human Rights" in International Human Rights and Negotiations Among Civilizations Seminar Articles" ed. Mofid University Administration, (Ghom: Mofid University Publishing, 2001) 211-226

72- Morteza Motahari, Women's Rights in Islamic Legal System, $8^{\text {th }}$ ed. (Tehran: Sadra Publishing, 1980)

73- $\quad$ Tajzaman Danesh, Prisoners' Rights and Science of prisons, $3^{\text {rd }}$ ed. (Tehran, 1997)

74- $\quad$ Mahiar Khalili, History of Torture and Murderin Iran, $1^{\text {st }} \mathrm{ed}$. (Tehran, 1980)

75- $\quad$ Mohammad Ashouri, Criminal Justice, $1^{\text {st }}$ ed. (Tehran: Ganje Danesh Publishing, 1997)

76- Mohammad Ashouri, Criminal Procedural Law, Vol.1, (Tehran: Samt Publishing Co., 1996)

77- Abbas Manoochehri, Iranian Political System, $1^{\text {st }}$ ed., (Tehran: Cultural and International Studies Center Press, 2002)

78- Mohammad Hussein Aliabadi, History of Law, (Tehran: University of Tehran Press, 1957)

79- Abolkalam Azad, Great Cyrus, Translated by Dr. Bastani Parizi to Persian (Tehran, 1990)

80- $\quad$ Ahmad Matin Daftari, Human Rights and International Support, $1^{\text {st }}$ ed., (Tehran: Bahman Publishing, 1960)

81- Morteza Ravandi, The History of Law and Justice In Iran, (Tehran: Cheshmeh Press, 1989)

82- Elton L. Daniel ,Society and Culture in Qajar Iran, (Los Angeles: Mazda Publishing, 2002)

83- Hamzeh Sardadvar, The Mystery of Qajar, (Tehran: Elm Publishing Co., 2001)

84- $\quad$ S. A. Mousavi, Torture in the Iranian Law, UN and Council of Europe Criminal Policy, (Tehran: Khate Sevom Publishing, 2003)

85- George Cruzan, Persia and the Persian Question, vol. 1 (Tehran: Elmi va Farhangi Publishing Co., 1983)

86- Karim Mojtahedi, New Philosophical Ideas in West and Iranian People, (Tehran: Temporary History of Iran Institution Press, 2000)

87- $\quad$ Fereidoun Adamiat, Amir Kabir and Iran, $8^{\text {th }}$ ed., (Tehran: Kharazmi Publishing, 1999)

88- Naser Enghetaa, Amir Kabir: A Light in Darkness, $2^{\text {nd }}$ ed. (Los Angeles: Ketab Corp., 2002)

89- Mohammad Reza Afshari, "The Historians of the Constitutional Movement and the Making of the Iranian Populist Tradition", International Journal of Middle East Studies, 1993, 25(3): 477-494

90- Edward J. Brown, History of Mashrooteh Revolution, Translated by Mehri Ghazvini, (Tehran: Nashre Kavir, 2001)

91- Ghasem Ghasemzadeh, Constitutional Law, ed. 1, (Tehran: Tehran University Press, 1955) 
92- Farhad Rostami, Pahlavies: Reza Sahah, Vol.1, (Tehran: Iranian History studies Institution Press, 1999)

93- Mohammad Dehnavi, "Pages from History" in Contemporary Iranian History, ed. Iranian History Institute, Vol.1

94- Hussein Makki, "Coup of 1920, Dr. Mossadegh and Oil" an interview made by Iranian History studies Institution, March 1996

95- Ziaoddin Sadrolashrafi, A memory about Kasravi, Derang Bi-monthly, third year, No.11, March 2003

96- $\quad$ Mahmood Hakimi, Stories of Reza Shah Age, $2^{\text {nd }}$ ed. (Tehran: Ghalam Publishing, 1992) at 261

97- Chehrzad Bahar, Collection of Bahar's Poems, Vol.2 (Tehran: Toos Press Co., 2001)

98- $\quad$ Ali Ansari, A History of Modern Iran Since 1921 The Pahlavis and After, $1^{\text {st }}$ ed. (London: Longman, 2003)

99- Shirin Ebadi, History and Human rights Documents, (Tehran: Roshangaran Publishing, 1994)

100- Mohammad Hashemi, "Protecting Citizens in Islamic System, Iranian Law and International Law" in International Human Rights and Negotiations Among Civilizations Seminar Articles Collection" ed. Mofid University Administration, (Ghom: Mofid University Publishing, 2001)

101- Abdolamir Manshdavi, Prison over the History, $1^{\text {st }}$ ed., (Ahvaz, Iran: Khoozestan Province Prisons Affairs Office, 1999)

102- Barzin, Saeed. "Constitutionalism and Democracy in the Religious Ideology of Mehdi Bazargan", British Journal of Middle Eastern Studies, 1994 21(1)

103- Habibollah Davaran \& Farhad Behbahani, Two Memoirs of prison: In Haji Party \& The Story of a Confession, (Tehran: Omide Farda Publications, 2001)

104- Abolfazl Ghazi, Constitutional Law and Political Institutions, $1^{\text {st }}$ ed. (Tehran: Tehran University Press, 1991)

105- The Entire Negotiations During the Final Assessing of the Islamic Republic of Iran Constitution, Vol. 1, (Tehran: Parliament Publishing, 1985) at 619-20, online; GC website: http://www.irisn.com/ketabkhaneh/mashroh/01/MATN_MASHROH_MOZARAKERAT_30.HTM

106- Jalalodin Madani, Islamic Republic of Iran's Constitution, Vol. 1, (Tehran: Ganje Danesh Press, 1990)

\section{Iranian Laws and Parliamentary Bills:}

107- Islamic Republic of Iran Constitution, Adopted on: 24 Oct 1979, Effective since: 3 Dec 1979, Amended on: 28 July 1989, available online(Iran Embassy in Ottawa website):

http://www.salamiran.org/IranInfo/State/Constitution/

108- Public Punishment Code, Official Gazette, Jan. 26, 1926, Vol. 1, Series 5 at 69

109- Criminal Procedure Code, National Parliament, July 22, 1930, Official Gazette No. 496, Duration 7, Vol. 1, at 152

110- Code of Revising A Part of Criminal Procedure, National Parliament, Feb. 20, 1957, Official Gazette No. 3562, Duration 19, Vol. 4, at 2200

111- Civil Code, Official Gazette, April. 10, 1935, Vol. 1, Series 10 at 4.

112- Code of Permission for Joining Iran to the Geneva Conventions, Official Gazette, Dec. 20, 1955, Vol. 1, Series 18, at589. 
113- Military Judicial Procedure and Punishment Code, Official Gazette, Dec. 24, 1939, Vol.1, Series 12 at 70

114- Code of Permission for Joining Iran to the Covenant on Civil and Political Rights, Official Gazette, May 7, 1975, Vol. 16, Series 23, at 3678

115- Tazirat Code (Ghanoone Raje Be Mojazate Eslami), Iranian Islamic Parliament, Oct. 12, 1980, online (Ghavanin Website): http://www.ghavanin.com/detail.asp?id=1138

116- Hodood \& Qisas Code, Judicial Committee to the National Parliament, approved 11 Oct. 1982, Official Gazette 10987. online (Ghavanin Website): http://www.ghavanin.com/detail.asp?id=1086

117- Islamic Criminal Code, July 29, 1991, approved by the Judicial Committee to the Parliament and amended Nov. 27, 1991 by Expediency Council, Official Gazette no. 13640, January 1, 1991.

118- Islamic Criminal Code, Islamic Parliament, May 22, 1996, online(Ghavanin Website): http://www.ghavanin.com/detail.asp?id=1232

119- Procedures in the General and Revolutionary Courts, Official Gazette 1591, 10 October 1999

120- Code of Revising A Part of Criminal Procedure, National Parliament, Feb. 20, 1957, Official Gazette No. 3562, Duration 19, Vol. 4, at 2200.

121- Permission for Joining Iranian Government to the Convention on the Rights of the Child Code, National Parliament, Feb. 19, 1993, online (Ghavanin website):

http://www.ghavanin.com/detail.asp?id=8649

122- Islamic Revolutionary Courts Bylaw, Revolutionary Counsil, 1979, Official Gazette No. 7/2482.

123- Prisons and Security and Correctional Measures Organization Bylaw, assembly of Ministers, Aug. 29, 1982, Official Gazette No. 10924

124- Bill To Protect The Rights Of Accused Or Convicted People, Laws Department of the Parliament Bulletin, $6^{\text {th }}$ duration, $3^{\text {rd }}$ year, No. 700,2003 ; online: Parliament Website; www.mellat.majlis.ir/tarhha20\%va20\%lavayeh.htm/601-700/700.htm

125- "Bill On Protecting The Rights of Accused or Convicted People will be discussed in Judicial Committee" Khaneh Mellat (Parliament) Daily, Saturday Oct. 25, 2003, online; parliament website: www.mellat.majlis.ir/commissions $20 \%$ news.htm/gazaayee $/ 1382 . \mathrm{htm}$

126- Bill to Join Convention Against Torture and Other Cruel, Inhuman or Degrading Treatment or Punishment, Laws Department of the Parliament Bulletin, $6^{\text {th }}$ duration, $3^{\text {nd }}$ year, No. 603, July. 23, 2003; online: Parliament Website; www.mellat.majlis.ir/tarhha20\%va20\%lavayeh.htm/601700/603.htm

127. Implementation of Article 38 Bill, Laws Department of the Parliament Bulletin, $6^{\text {th }}$ duration, $2^{\text {nd }}$ year, No. 385, Dec. 10, 2001; online: Parliament Website; www.mellat.majlis.ir/tarhha20\%va20\%lavayeh.htm $/ 301-400 / 385 . \mathrm{htm}$

\section{UN documents:}

128- Charter of the United Nations, June 26, 1945, 59 Stat. 1031, T.S. 993, 3 Bevans 1153

129- Universal Declaration of Human Rights, GA Res. 217(III), 3d Sess. Supp. No.13, UN Doc. A/810 (1948)

130- International Covenant on Civil and Political Rights, 19 December 1966, 999 U.N.T.S. 171, Can. T.S. 1976 No. 47, 6 I.L.M. 368 (entered into force 23 March 1976). 
131 - "The International Covenant on Economic, Social and Cultural Rights (ICESCR)" Adopted and opened for signature, ratification and accession by General Assembly res. 2200A (XXI), 16 December 1966, entry into force 3 January 1976, in accordance with article 27.

132- Convention Against Torture and Other Cruel, Inhuman or Degrading Treatment or Punishment, G.A. res. 39/46, [annex, 39 U.N. GAOR Supp. (No. 51) at 197, U.N. Doc. A/39/51 (1984)], entered into force June 26, 1987.

133- Optional Protocol to the Convention Against Torture and Other Cruel, Inhuman or Degrading Treatment or Punishment, G.A. res. A/RES/57/199, adopted Dec. 18, 2002 [reprinted in 42 I.L.M. 26 (2003)

134- Principles of medical ethics relevant to the role of medical personnel, particularly physicians, In the protection of prisoners and detainees against torture and other cruel, inhuman or degrading treatment, UNGA Res. 37/194, 18 Dec. 1982

135- Declaration on the Protection of All Persons from Being Subjected to Torture and Other Cruel, Inhuman or Degrading Treatment or Punishment, G.A. res. 3452 (XXX), annex, 30 U.N. GAOR Supp. (No. 34) at 91, U.N. Doc. A/10034 (1975).

136- Standard Minimum Rules for the Treatment of Prisoners, GA Res, 663 (XXIV). UN Doc. (1955)

137- Code of Conduct for Law Enforcement Officials, UNGA Res. 341/169, 17 Dec. 1979

138- Body of principles for the protection of all persons under any form of detention or imprisonment, UNGA Res. 43/173, Dec. 9, 1988

139- The convention on the rights of the child, UNGA Res. 44/25, Nov. 20, 1989

140- Basic Principles for the Treatment of Prisoners, GA res. 45/111, 14 December 1990,

141- Basic Principles on the Role of Lawyers, adopted by the $8^{\text {th }}$ United Nations Congress on the Prevention of Crime and the Treatment of Offenders, Havana 27 August to 7 September 1990. U.N. Doc. A/CONF. 144/28/Rev. 1

142- Commission on Human Rights Resolution on Torture and other cruel, inhuman or degrading treatment or punishment, UN Doc. E/CN.4/RES/2002/38

143- ICCPR General Comment No. 21, UN Human Rights Committee, Sess. 44, Apr. 10, 1992, HRI/GEN/1/Rev.1

144- Written statement submitted by Palestinian Centre for Human Rights, Commission on Human . Rights, $59^{\text {th }}$ sess., UN Doc. E/CN.4/2003/NGO/200, 17 March 2003,

145- Special Report on Israel, UNCAT, $18^{\text {th }}$ Sess, $296^{\text {th }} \mathrm{mtg}$, UN Doc. CAT/C/SR.296, (1997)

146- ICCPR general comment no.20, Human Rights Committee, Sess. 44, 10/03/92,

147- UN Commission on Human Rights Resolution, UN Doc E/CN.4/RES/1985/33,13 March 1985.

148- Report of the Special Rapporteur on the question of torture, submitted in accordance with Commission resolution 2002/38, UN Doc. E/CN.4/2002/68, 17 Dec. 2002, Sess. 59

149- UN Commission on Human Rights Resolution, UN Doc E/CN.4/RES/1985/33,13 March 1985.

150- Commission on Human Rights resolution, UN Doc. E/CN.4/RES/2002/38, 57th meeting, 23 April 2003

151- Proclamation of Teheran, Final Act of the International Conference on Human Rights, Teheran, 22 April to 13 May 1968, U.N. Doc. A/CONF. 32/41 at 3 (1968)

152- Status of the Convention Against Torture and Other Cruel, Inhuman or Degrading Treatment or Punishment, Report of the Secretary-General, Commission on Human Rights, Sess. $16^{\text {th }}$, E/CN.4/2004/52, 28 January 2004 
153- Tthe Statute of The International Criminal Tribunal for Rwanda, UN Res.1165 (April 30, 1998)

154- The Statute of the International criminal Tribunal for the Former Yugoslavia, Security Council Res. 827,25 May 1993

155- Views of the Committee Against Torture under article 22 of the Convention Against Torture and Other Cruel, Inhuman or Degrading Treatment or Punishment, Committee Against Torture, Sess. $19^{\text {th }}$, Communication No. 28/1995: Switzerland, CAT/C/19/D/28/1995, 10 November 1997

156- Implementation of article 3 of the Convention in the context of article 22, General Comment no. 1, Committee Against Torture, UN Doc. A/53/44, annex IX, Sess. $19^{\text {th }}$, meeting $317^{\text {th }}$, Nov. 21, 1997.

157- Summary record of the public part of the 246th meeting : Armenia, Committee Against Torture, Sess. $16^{\text {th }}$, UN Doc. CAT/C/SR.246, Geneva, 3 May 1996

158- Summary record of the public part of the 279th meeting : Georgia, Poland, Committee Against Torture, Sess. $17^{\text {th }}$, Geneva, Doc. CAT/C/SR.279, 21 March 1997

159- Summary record of the first part of the 354th meeting : Yugoslavia, United Kingdom of Great Britain and Northern Ireland, Committee Against Torture, CAT/C/SR.354, 18 November 1998, Sess. 21, Geneva, at C 14 \& D 17

160- Cameroon: Concluding Observation, Committee Against Torture, Sess. 45, CAT A/45/44, 1990

161- Summary record of the 419th meeting : China, Poland, COMMITTEE AGAINST TORTURE, Twenty-fourth session, CAT/C/SR.419, 12 May 2000, Geneva

162- Communication No. 236/2003: Switzerland, Committee Against Torture, Sess. $31^{\text {th }}$, $\mathrm{CAT} / \mathrm{C} / 31 / \mathrm{D} / 236 / 2003,14$ November 2003

163- Report of the Committee Against Torture to $57^{\text {th }}$ session of the UN General Assembly, CAT $\mathrm{A} / 57 / 44,01 / 11 / 2002$

164- Concluding Observations : Egypt, Committee Against Torture, Sess. 29, 11 - 22 Nov. 2002, CAT/C/XXIX/Misc.4

165- UN Security Council 3093rd Meeting Resolution S/RES/764 July 13, 1992

166- Statute of the International Tribunal for the Prosecution of Persons Responsible for Serious Violations of International Humanitarian Law Committed in the Territory of the Former Yugoslavia since 1991, Security Council Resolution 808, U.N. Doc. S/25704 (Feb. 22, 1993)

167- Rome Statute of the International Criminal Court, U.N. Doc. A/CONF.183/9, U.N.T.S. 3, entered into force July 1,2002

168- United Nations Voluntary Fund for Victims of Torture, UNGA Res. A/RES/36/151, 16 December 1981

169- The Vienna Declaration and Program of Action, UNGA Res. A/CONF.157/23, 12 July 1993,

170- Communication No. 120/1998: Australia, Committee Against Torture, Sess. $22^{\text {nd }}$, UN Doc. CAT/C/22/D/120/1998, 25 may 1999

171- Torture and other Cruel, Inhuman and Degrading Treatment or Punishment, Report of the Special Rapporteur, Mr. Peter Koojimans, February 19, 1986, UN Doc. E/CN.4/1986/15

172- Peter Koojimans, Report of the Special Rapporteur submitted pursuant to Commission on Human Rights Resolution 1992/32, Commission on Human Rights, $49^{\text {th }}$ Sess., UNDoc. E/CN.4/1993/26, 15 Dec. 1992

173- Torture and other Cruel, Inhuman and Degrading Treatment or Punishment, Report of the Special Rapporteur, Mr P. Kooijmans, 21 December 1991, UN Doc. E/CN.4/1992/17

174- Theo Van Boven, Report of the Special Rapporteur on torture of the United Nations Commission on Human Rights, UNGA Doc. E/CN.4/2004/56, Sess. 60 
175- Theo Van Boven, Report of the Special Rapporteur on the question of torture, Commission on Human Rights, $60^{\text {th }}$ Sess., UN Doc. E/CN.4/2004/56/Add.1, 23 March 2004

176- Theo Van Boven, Report of the Special Rapporteur submitted pursuant to Commission on Human Rights Resolution 2002/38, Commission on Human Rights, $58^{\text {th }}$ Sess., UNDoc.

E/CN.4/2003/68/Add.1, 27 Feb. 2003

177- Situation of human rights in the Islamic Republic of Iran, , Sess. $42^{\text {nd }}$, UNGA Res. A/42/648,

178- Situation of human rights in the Islamic Republic of Iran, , Sess. $43^{\text {rd }}$, UNGA Res. A/43/705

179- Situation of human rights in the Islamic Republic of Iran, UNGA Doc. A/53/423, General Assembly, $53^{\text {rd }}$ ess.. 23 Sep. 1998

180- Situation of human rights in the Islamic Republic of Iran, UNJAOR, $56^{\text {th }}$ Sess, UN Doc A/56/278, (Aug.2001)

181- Situation of human rights in the Islamic Republic of Iran, UNGA Doc. A/52/472, General Assembly, 52 ${ }^{\text {nd }}$ Sess., 15 October 1997.

182- Situation of human rights in the Islamic Republic of Iran, UNGA Doc. A/54/365, 54 $4^{\text {th }}$ Sess., 21 September 1999

183- Report On the Human Rights Situation in the Islamic Republic of Iran, Commission on Human Rights, Sess. $51^{\text {st }}$, 16 Jan. 1995, UN DOC. E/CN.4/1995/55

184- $\quad$ Nigel Rodley, Report of the Special Rapporteur submitted pursuant to Commission on Human Rights Resolution 1995/35, Commission on Human Rights, 50 th Sess., UNDoc. E/CN.4/1995/34, 12 Jan. 1995

185- Nigel Rodley, Report of the Special Rapporteur submitted pursuant to Commission on Human Rights Resolution 1995/35, Commission on Human Rights, 52 ${ }^{\text {nd }}$ Sess., UNDoc. E/CN.4/1996/35, 9 Jan. 1996

186- Nigel Rodley, Report of the Special Rapporteur submitted pursuant to Commission on Human Rights Resolution 2000/43, Commission on Human Rights, 57 $7^{\text {th }}$ Sess., UNDoc. E/CN.4/2001/66, 25 Jan. 2001

187- Nigel Rodley, Report of the Special Rapporteur submitted pursuant to Commission on Human Rights Resolution 2001/62, Commission on Human Rights, $58^{\text {th }}$ Sess., UNDoc. E/CN.4/2002/76/Add.1, 14 March. 2002

188- Nigel Rodley, Report of the Special Rapporteur, UN Doc. E/CN.4/1999/61, Sess. 55 $5^{\text {th }}, 12$ Jan. 1999

189- Torture and other Cruel, Inhuman and Degrading Treatment or Punishment, Report of the Special Rapporteur, Mr. Nigel Rodley, Sess. 53 $3^{\text {th }}, 10$ Jan. 1997, UN Doc. E/CN.4/1997/7,

190- Nigel Rodley, Report of the Special Rapporteur, UN Doc. E/CN.4/1998/38/ADD.1, Sess. 54 ${ }^{\text {th }}, 24$ Dec. 1997

191- Reynaldo Galindo Pohl, Report On the Human Rights Situation in the Islamic Republic of Iran, UN DOC. E/CN.4/1990/24

192- Reynaldo Galindo Pohl, Report On the Human Rights Situation in the Islamic Republic of Iran, UN Doc. E/CN.4/1991/35

193- Reynaldo Galindo Pohl, Final Report on the situation of human rights in the Islamic Republic of Iran pursuant to Commission resolution 1992/67 of 4 March 1992, UN Doc. E/CN.4/1993/41, Commission of Human Rights, Sess. $49^{\text {th }}, 28$ January 1993

194- Reynaldo Galindo Pohl, Report On the Human Rights Situation in the Islamic Republic of Iran, UN Doc. E/CN.4/1987/23 
195- Reynaldo Galindo Pohl, Report On the Human Rights Situation in the Islamic Republic of Iran, Commission on Human Rights, Sess. $50^{\text {th }}, 2$ February 1994, UN DOC. E/CN.4/1994/50,

196- Maurice Copithorne, Interim report on the situation of human rights in the Islamic Republic of Iran, submitted by the Special Representative of the Commission on Human, UNGA , $50^{\text {th }}$ sess., 20 October 1995, A/50/661,

197- Maurice Copithorne, Report on the situation of human rights in the Islamic Republic of Iran, prepared by the Special Representative of the Commission on Human Rights, pursuant to Commission resolution 1995/68 of 8 March 1995 and Economic and Social Council decision 1995/279 of 25 July 1995, 52 ${ }^{\text {nd }}$ sess., UN Doc. E/CN.4/1996/59, 21 March 1996

198- Maurice Copithorne, Report on the situation of human rights in the Islamic Republic of Iran, prepared by the Special Representative of the Commission on Human Rights, pursuant to Commission resolution 1995/68 of 8 March 1995 and Economic and Social Council decision 1995/279 of 25 July 1995, 53 ${ }^{\text {rd }}$ sess., UN Doc. E/CN.4/1997/63, 11 Feb. 1997

199- Interim report of the Special Rapporteur of the Commission on Human Rights on the situation of human rights in the Islamic Republic of Iran, UNGA Doc. A/55/363, 55 ${ }^{\text {th }}$ sess., 8 Sep. 2000

200- Maurice Copithorne, Report on the situation of human rights in the Islamic Republic of Iran, prepared by the Special Representative of the Commission on Human Rights, , pursuant to Commission resolution 1997/54, 54 ${ }^{\text {th }}$ Sess., UN Doc. E/CN.4/1998/59, 28 January 1998

201- Maurice Copithorne, Report of the special representative of the Commission of Human Rights on the situation of human rights in the Islamic Republic of Iran, UNJAOR, $54^{\text {th }}$ Sess, UN Doc 4/1999/32, (1999)

\section{NGO documents:}

202- Amnesty International, Kenya: Government fails to take action to stop torture, Al INDEX: AFR 32/04/97, 8 January 1997, News Service 247/96

203- Amnesty international report, Sad fact that fight against torture must continue in the 21st Century, AI INDEX: POL 30/006/2003, 25 June 2003

204- Amnesty International, When torturers can't hide, the torture stops, call to take action, released on June 26, 2004 .

205- Amnesty International Report, Israel Supreme Court To Rule on Torture and the Holding of Hostages, AI Index: MDE 15/39/99, 25 MAY 1999

206- Amnesty International, An Open Letter To President George W. Bush on the question of Torture and Cruel, Inhuman or Degrading Treatment, AI Index: AMR 51/078/2004, 7 May 2004,

207- Amnesty International report on him: Iran: Imminent flogging/arrest without charge/medical concern, Nasser Zarafshan, lawyer, Amnesty International, AI Index: MDE 13/012/2002, 16 August 2002

208- Amnesty International, Report on Torture. London: 1973,

209- Amnesty International Report, AI Index: ACT 40/002/2004 (Public), News Service No: 157, 26 June 2004, 5

210- Amnesty International, Iran Political Executions, AI INDEX: MDE 13/29/88 DISTR: SC/CO/GR, December 1988.

211- Amnesty International, Annual Report on Iran 1999, online: http://www.amnesty.org/ailib/aireport/ar99/mde13.htm. 
212- Amnesty International, Annual Report on Iran 2000, online:

http://www.web.amnesty.org/web/ar2000web.nsf/f5ea2b18926bc708802568f500619c95/2f122285c de39a94802568f200552931!OpenDocument.

213- Amnesty International, Iran: Only an independent investigative body can serve justice and human rights, AI Index: MDE 13/026/2003 (Public), 1 August 2003

214- Iran: Veto on Torture Bill Condemned, HRW News, New York, June 12, 2002, online, HRW website: www.hrw.org/press/2002/06/iran0612.htm

215- Human Rights Watch, Iran Power versus Choice: Human Rights and Parliamentary Elections in the Islamic Republic of Iran, Vol. 8, No. 1 (E), March 1996. online (HRW website): www.hrw.org/reports/1996/Iran.htm

216- A journalist at Risk, Human Rights Watch News, New York, December 22, 2001 online: http://www.hrw.org/press/2001/12/iran122201.htm

217- The Large Gate of Evin, APT Journal, Vol. 0, 1995, 4-5.

\section{Other international documents:}

218- European Convention for the prevention of torture and inhuman or degrading treatment or punishment, 26 November 1987; Inter-American Convention to prevent and punish torture, 9 December 1985.

219- Geneva Convention (I) for the Amelioration of the Condition of the Wounded and Sick in Armed Forces in the Field. Geneva, 12 August 1949

220- Geneva Convention (II) for the Amelioration of the Condition of Wounded, Sick and Shipwrecked Members of Armed Forces at Sea. Geneva, 12 August 1949.

221- Geneva Convention (III) relative to the Treatment of Prisoners of War, Adopted on 12 August 1949 by the Diplomatic Conference for the Establishment of International Conventions for the Protection of Victims of War, held in Geneva from 21 April to 12 August, 1949. Entered into force 21 October 1950

222- Geneva Convention Relative to Protection of Civilian Persons in Time of War, 75 U.N.T.S. 287, entered into force Oct. 21, 1950

223- Protocol Additional to the Geneva Conventions of 12 August 1949, and relating to the Protection of Victims of Non-International Armed Conflicts (Protocol II), 8 June 1977

224- The European Convention on Human Rights and Fundamental Freedoms, Council of Europe, European Treaties, ETS No.5, Rome Nov. 4, 1950, entered into force Nov. 4, 1953

225- The European Convention for the prevention of torture and inhuman or degrading treatment or punishment, Council of Europe, ETS No.126, Strasbourg, 1987

226- Antonio Cassese, "The European Committee for the Prevention of Torture and Inhuman or Degrading Treatment or Punishment" in The international fight against torture, ed. Antonio Cassese ( Baden-Baden, 1991)

227- American Convention on Human Rights, O.A.S.Treaty Series No. 36, 1144 U.N.T.S. 123 entered into force July 18, 1978, reprinted in Basic Documents Pertaining to Human Rights in the InterAmerican System, OEA/Ser.L.V/II.82 doc.6 rev.1

228- African Charter on Human and Peoples' Rights, adopted June 27, 1981, OAU Doc. CAB/LEG/67/3 rev. 5, 21 I.L.M. 58 (1982), entered into force Oct. 21, 1986. 


\section{Cases :}

229- The Public Committee Against Torture in Israel $v$ The Government of Israel et al, Case no. HCJ 5100/94, Israeli Supreme Court sitting as High Court of Justice, Sep. 6, 1999

230- Ireland v. The United Kingdom, (5310/71) [1978] ECHR 1 (18 January 1978), 66-67

231- Selmouni v. France, European Court of Human Rights, Case no. 25803/94, [1999] ECHR 66 (28 July 1999)

232- Aksoy v. Turkey, Judgment of the ECHR, 18 December 1996 [1996] IIHRL 110 (18 December 1996)

233- Tomasi v. France, (12850/87) [1992] ECHR 53 (27 August 1992)

\section{Other sources:}

234- "Holy Koran", (Tehran: Ershad Printing, 2001)

235- Hammurabi Code far from our hands in Paris, Report by Cultural Department, Iranian National Heritage Organization, Miras News Agency, Feb. 21, 2004

236- Antonio M. Taguba, Article 15-6 Investigation of 800th Military Police Brigade: US Army Report on Abuse of Iraqi Prisoners, May 5, 2004

237- Rumsfeld Testifies Before Senate Armed Services Committee, Washington Post, Friday, May 7 , 2004

238- Dershowitz Alan: Torture could be justified, CNN, Monday, March 3, 2003

239- Dershowitz Alan, A choice among evils, Globe and Mail, Wednesday, March 5, 2003 at A17

240- "An organized attack to Zarafshan in prison", Gooya News, Saturday, July 31, 2004

241- Emadodin Baghi, Legitimizing Torture, Yaseno Daily, Dec. 2, 2003

242- Emadodin Baghi, Human Rights or Believers' Rights, Shargh Daily, Tuesday Dec. 2, 2003

243- Emadodin Baghi, Continuing Ijtihad, Shargh Daily, Sep. 25, 2003

244- Parliament allows Government to Join The UN Convention Against Torture, ISNA News Agency, July 23, 2003, News No. 8205-00137, online, ISNA website:

http://www.isna.ir/news/NewsCont.asp?id=259751\&lang=P

245- Joining the Convention is necessary, ISNA News Agency, July 23, 2003, News No. 8205-00515, online, ISNA website: http://www.isna.ir/news/NewsCont.asp?id=260129\&lang=P

246- "Commission Continues Revising The Bill To Join UN Convention Against Torture" Khaneh Mellat (Parliament) Daily, Tuesday, Oct. 28, 2003, online; parliament website: www.mellat.majlis.ir/commissions $20 \%$ news.htm/gazaayee/1382.htm

247- last steps of the reformist parliament for human rights, Vaghayeh Etefaghieh Daily, Monday, May $25,2004$.

248- "Comments on Bill to Join Iran to the UN Convention Against Torture" legal studies bureau of the parliament research center, khaneh Mellat Daily, Monday Aug. 7, 2003. online: http://mellat.majlis.ir/archive/1382/researchcenter/hoghooghi/news1.htm

249- Report on bill to protect the rights of accused or convicted persons, legal studies bureau of parliament research center, Khaneh Mellat (Parliament) Daily, Mon. Nov. 17, 2003, online; parliament website: www.mellat.majlis.ir/archives/1382/researchcenter/hoghooghi/news $1 . \mathrm{htm}$ 
250- Kasravi's defence in Ahmadi's Court, Parcham Daily, No.164, Wednesday, Aug. 16, 1942.

251- Ibrahim Nabavi, Khatami, Resign please, Iran Emrooz electronic daily, July 12, 2003, online (Iran Emrooz website): http://www.iran-emrooz.de/archiv/maqal/1382/nabavi820424.html

252- Conservatives claim victory in Iran, Sat, $21 \mathrm{Feb} 2004, \mathrm{CBC}$ News, online(CBC Website): http://www.cbc.ca/story/world/national/2004/02/21/iranvote_040221.html

253- Babak Seradjeh, People's Demands: Present, Free Thoughts on Iran Electronic Magazine, July 29, 2003, online (FTI Website): http://freethoughts.org/archives/000022.php

254- S. Bastani, Review of a file, Bonyan Daily, April 19, 2002, No.43, at 6 online: Bonyan website< http://news.gooya.com/2002/04/18/pdf/1804-07.pdfs.

255- Soltanian: they want to press on me, Bonyan Daily, April 16, 2002, No.40, at 2 online: Bonyan website $<$ http://news.gooya.com/2002/04/16/pdf/1804-07.pdf $>$

256- Aref: All my confessions were wrong, ISNA news agency, 27 Oct. 2003, News no. 8208-02100, online; ISNA Website: www.isna.ir/news/newscont.asp?id $=3019718$ \&lang $=p$

257- Students' open Letter to Kofi Annan, Norooz Daily, Monday, July 8, 2003, at 1; online, Bionvan Website: www.bionvan.com/univs.php?eat=news\&show $=$ 20416-20

258- "A drop of the sea, if it is with the sea" letter of Dr. Maleki to the Iranian students and scholars, Press Release: SMCCD Political Committee, Tuesday August 12, 2003; online, Scoop website: http://www.scoop.co.nz/mason/stories/WO0308/S00127.htm

259- " 'Ali Khamenehee, the supreme leader of Iran: Murders were against Iran's nation and government", Hamshahri Daily, No.1738, 10 Jan. 1999, at 1

260- Report of Special Committee on Zahra Kazemi's death, Hamshahri Daily, No. 3113, Monday July 21, 2003, online (Hamshahri website):

http://www.hamshahri.org/hamnews/1382/820430/news/siasi.htm\#s14255

261- Mohammad Ali Abtahi (Vice President to Mr. Khatami), About Zahra Kazemi's File, July 16, 2004, an article on his weblog, online: http://www.webnevesht.com/weblog/?id=1090066798

262- "Khatami Wrote to Shahroodi: Who is the murderer", Hamshahri Daily, no. 3114, Tuesday July 22, 2003, online (Hamshahri website): http://www.hamshahri.org/hamnews/1382/820431/news/siasi.htm\#s14780

263- "Kazemi Murder Enquiry Farce Continues As Court Says Only One Person Responsible", Middle East Press Released, Reporters Without Borders, Article 8092, Sep. 26, 2003; Online: www.rsf.org/article.php3?id_article $=8092$

264- Jim Muir (BBC reporter in Tehran), Iran reformists denounce judges, Tuesday, 28 October, 2003, online (BBC website): http://news.bbc.co.uk/1/hi/world/middle_east/3220173.stm

265- Mohsen Armin (A member of Parliamentary National Defence Committee in sixth parliament), Report on Zahra Kazem's murder, Official speach in Parliament, Sunday, July. 20, 2003

266- $\quad T h e$ Nobel Peace Prize, The Norwegian Nobel Committee, Press Release, Oslo, Oct. 10, 2003; Online: www.nobel.se/peace/laureates2003/press.html

267. Kazemi's family Lawyers: The Court is not Competent to Hear the Case, ISNA news agency, Thu 150704

268- Call for presence of witnesses in the court, Shargh Daily, July 18, 2004, online (Shargh Website): http://www.shargh.ws/830428/index.htm

269- Court: No body is guilty, Shargh Daily, July 25, 2004, online (Shargh Website): http://www.shargh.ws/830504/index.htm 
270- 'Minister failed me,' Kazemi's son says ,Online news CBC Montreal, Jul 28 2004, online(CBC website): http://montreal.cbc.ca/regional/servlet/View?filename $=q c$ kaz20040728

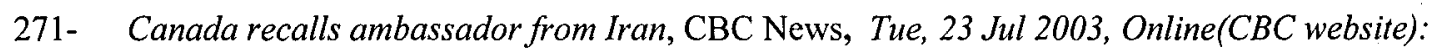
http://montreal.cbc.ca/regional/servlet $/$ View?filename $=$ qc $\_$kazemi20030723

272- Torture in Iran, an interview with Kambiz Noroozi, Bonyan newspaper, no 20, March 8, 2002 at 4

273- "Comments on Bill to Join Iran to the UN Convention Against Torture" legal studies bureau of the parliament research center, khaneh Mellat daily, Monday Aug. 7, 2003. online: http://mellat.majlis.ir/archive/1382/researchcenter/hoghooghi/news1.htm

274- An Interview with the Head of Iranian Bar Association, ISNA News Agency, Sep. 12, 2003. online: http://news.gooya.com/2003/09/12/1209-p-22-php

275- Iranian ex-journalist put on trial on spying charges, The New York Times, Friday, March 15, 2002 online: http://www.iht.com/articles/51340.htm

276- Interview with Bahman Keshavarz about new bill on torture, ISNA news agency, Sep. 12, 2003, online, Gooya website: http://news.gooya.com/2003/09/12/1209-p-22-php

277- Tehran MP Criticizing Revolutionary Guard and the Judiciary, the speech of Fatemeh Haghighatjoo in Iran's Parliament, Khaneh Mellat Daily (Parliament Boultin) Saturday Nov. 12, 2003. Online; Parliament website: http://mellat.majlis.ir/archive/1382/08/18/notghha.htm\#5

278- We are against torture, even torturing ex-torturers is not acceptable, by Farhad Behbahani, Asre Azadegan Daily, March 29, 2000.

279- Tehran Mp Criticizing Revolutionary Guard and the Judiciary, the speech of Fatemeh Haghighat joo in Iran's Parliament, Khaneh Mellat Daily (Parliament Boultin) Saturday Nov. 12, 2003. Online; Parliament website: http://mellat.majlis.ir/archive/1382/08/18/notghha.htm\#5

280- Iran: Parliamentarian Convicted, Human Rights Watch News, Jan. 4, 2002. Online; HRW website: www.hrw.org/press/2002/01/iran0104.htm

281- Analysis: End of an era of reform?, By Jim Muir, BBC News, Thursday, 19 February, 2004, Online(BBC website): http://news.bbc.co.uk/1/hi/world/middle east/3505049.stm

282- Comments on the bill of Banning Torture, Mahmood Akhondi, Nowrooz Daily, Jan. 31, 2001 at 8

283- An Interview with Naser Ghavami, the head of judicial committee of Parliament, Iran Kar Press Agency, Monday Oct. 27, 2003; online Gooya Website: http://news.gooya.com/politics/archives/001025.php

284- Interview with Meisam Saeedi, an MP from Tehran, , ISNA news agency, July. 23, 2003, News no. 8205-00515. online, ISNA website: http://www.isna.ir/news/newsprint.asp?ip=260129

285- Sanei and Ardebili: Bill on Banning Torture is not against Islam, Norooz Daily, No. 300, April. 1, 2002

286- Commission Continues Revsing The Bill To Join UN Convention Against Torture, Khaneh Mellat (Parliament) Daily, Tuesday, Oct. 28, 2003, online; parliament website: www.mellat.majlis.ir/commissions $20 \%$ news.htm/gazaayee/1382.htm

287- GC vetoed the bill against torture again, BBC Persian News, Mon. Sep. 9, 2003, online, BBC Website: www.bbc.co.uk/persian/iran/030909 mf torture.shtml\#top

288- The bill against torture sent to Expediency Council, Khaneh Mellat (Parliament) Daily, Wednesday, Nov. 12, 2003, online; parliament website: www.mellat.majlis.ir/archives/1382/08/21/parlemanttoday.htm\#7 